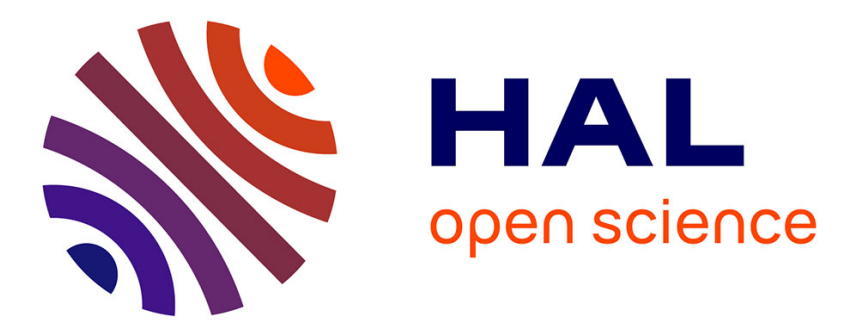

\title{
Species living in harsh environments have low clade rank and are localized on former Laurasian continents: a case study of Willemia (Collembola)
}

Andreas Prinzing, Cyrille d'Haese, Sandrine Pavoine, Jean-François Ponge

\section{- To cite this version:}

Andreas Prinzing, Cyrille d'Haese, Sandrine Pavoine, Jean-François Ponge. Species living in harsh environments have low clade rank and are localized on former Laurasian continents: a case study of Willemia (Collembola). Journal of Biogeography, 2014, 41 (2), pp.353-365. 10.1111/jbi.12188 . hal-00940083

\section{HAL Id: hal-00940083 \\ https://hal.science/hal-00940083}

Submitted on 31 Jan 2014

HAL is a multi-disciplinary open access archive for the deposit and dissemination of scientific research documents, whether they are published or not. The documents may come from teaching and research institutions in France or abroad, or from public or private research centers.
L'archive ouverte pluridisciplinaire HAL, est destinée au dépôt et à la diffusion de documents scientifiques de niveau recherche, publiés ou non, émanant des établissements d'enseignement et de recherche français ou étrangers, des laboratoires publics ou privés. 


\section{Species living in harsh environments have low clade rank and are localized}

on former Laurasian continents: a case study of Willemia (Collembola)

\section{Andreas Prinzing, ${ }^{1,2 *}$ Cyrille A. D’Haese, ${ }^{3}$ Sandrine Pavoine, ${ }^{4,5}$ Jean-François Ponge ${ }^{6}$}

1. Université de Rennes 1, CNRS UMR 6553 ECOBIO: Ecosystèmes, Biodiversité, Evolution; Campus de Beaulieu, 263 avenue du Général Leclerc, 35042 Rennes Cedex, France. e-mail: andreas.prinzing@univ-rennes1.fr

2. Alterra, Centre for Ecosystem Studies, WUR, PO Box 47, 6700AA Wageningen, The Netherlands.

3. Muséum National d'Histoire Naturelle, Département Systématique et Évolution, CNRS UMR 7205, CP 50, 45 rue Buffon, 75005 Paris, France. e-mail: dhaese @ mnhn.fr

4. Muséum National d'Histoire Naturelle, Département Écologie et Gestion de la Biodiversité, CNRS-UPMC UMR 7204, 55-61 rue Buffon, 75005 Paris, France. e-mail: pavoine@mnhn.fr

5. Mathematical Ecology Research Group, Department of Zoology, University of Oxford, South Parks Road, Oxford OX1 3PS, UK.

6. Muséum National d'Histoire Naturelle, Département Écologie et Gestion de la Biodiversité, CNRS UMR 7179, 4 avenue du Petit-Château, 91800 Brunoy, France. e-mail: ponge@mnhn.fr

Running title: Use of harsh environments across a phylogeny

Word count (Abstract - references, included): 8446 words

Printed page estimation: title/abstract etc.: 1 page, Introdcution - Discussion : 5956 words $\cong$ 6 pages, 94 refernces $\cong 3$ pages, tables and figures: 1.5 pages (table 1 could be shifted to Appendix)

Estimate of number of journal pages required by table and figures: 1.5 (Tab. 1 could also be moved to an Appendix if needed)

${ }^{*}$ Corresponding author 
31

\section{ABSTRACT}

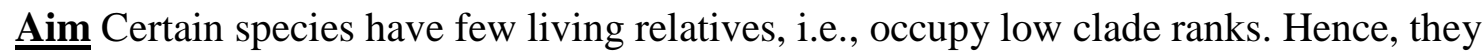
possess high conservation value and scientific interest as unique representatives of ancient lineages. However, we do not know whether particular environments favour the maintenance of low clade ranks or whether the distribution of environments across the globe affects the global distribution of clade ranks and, hence evolutionary uniqueness. In this study, we tested whether and how harsh environments decrease the clade ranks of the species that inhabit them.

\section{$\underline{\text { Location Global }}$}

Methods We described the phylogeny of the collembolan genus Willemia by a parsimonious method based on 52 morphological characters and estimated the species' use of harsh environments (polar, high-mountain, desert, polluted, waterlogged, saline, and acidic) from 248 publications.

$\underline{\text { Results }}$ We found that the use of different types of harsh environments is maintained among close relatives and has similar phylogenetic signals (except for the use of salinity). The use of harsh environments might therefore affect the diversification of lineages. Correcting for the phylogenetic non-independence of species, we found that species using harsh environments have comparatively low clade ranks. We also found that species using harsh environments occur almost exclusively on former Laurasian continents and that as a statistical consequence, Laurasian species tend to have lower clade ranks.

Main Conclusions We suggest that harsh environments maintain low-clade-rank species by decreasing, simultaneoulsy or successively, extinction and speciation, which may eventually explain the major variation in clade rank across the globe. 
54 Keywords abiotic stress; diversification; habitat; niche conservatism; phylogenetic

55 reconstruction; phylogenetic generalised least squares; phylogenetic principal components;

56 phylogenetic permutation; root-skewness test; tropical 


\section{INTRODUCTION}

Extant species can occupy very different clade ranks within a phylogenetic topology. Certain species have very few living relatives and thus occupy a low clade rank, whereas others have much higher clade ranks. Species of low clade rank are the sole extant representatives of their lineages and hence have a high evolutionary uniqueness: the loss of a low-clade-rank species implies the loss of more evolutionary history than the loss of a high-clade-rank species (Purvis et al., 2000; Prinzing et al., 2004; Colles et al., 2009). For this reason, it is important to understand whether low-clade-rank species are maintained to a greater extent in certain environments or regions than in others.

It has been suggested that species of low clade rank persist and accumulate in regions with low extinction rates (Willis, 1922; Condamine et al., 2012), notably due to relatively stable climates, especially in the tropics (Wiens \& Donoghue, 2004; Jablonski et al., 2006; Hawkins et al., 2007; Donoghue, 2008; Buckley et al., 2010). Furthermore, low clade rank has been suggested to reflect a relatively low speciation rate, as has been proposed for the regions outside the tropics (Willis, 1922; Jablonski, 1993, 1999; Chown \& Gaston, 2000; Jablonski et al., 2006). Overall, species of low clade rank can be expected to most likely accumulate in regions in which a low speciation (or immigration) rate very roughly outweighs a low rate of extinction (or emigration). There would be no net effect on species richness under such circumstances.

The distribution of clade ranks across regions has received considerable attention, whereas the distribution of clade ranks across types of environments (broadly, "habitats") has received much less attention. Bartish et al. (2010) have recently shown that within a region, particular harsh environments might be colonised by species of particularly low clade rank: across 40 different habitats in the Netherlands, those with extremely high soil moisture and 
extremely low soil $\mathrm{pH}$ were characterised by low mean clade ranks of their angiosperm inhabitants. However, this analysis was restricted to a single, small region and might not reflect (or influence) globally coherent patterns. Here, we define abiotically harsh environments as environments that tend to impose a major direct physiological stress on most species of a given lineage - i.e., a constraint on growth and reproduction (sensu Grime, 1977) — with the obvious exceptions of highly tolerant species and sub-lineages. We can speculate that harsh environments might indeed reduce extinction rates, as patches of harsh environments remain present at least locally at any given time in any region and maintain gene flow (Behrensmeyer et al. 1992), and species in harsh environments might rarely be driven to extinction by biotic interactions (Grime 1977, Callaway et al. 2002). In addition, harsh environments might possibly reduce speciation rates by reducing two of the major triggers of speciation: (i) recombination events, which become rarer with environmental harshness due to increased generation times (Grime 1977), and (ii) evolutionary arms races between prey and their natural enemies, which become less diverse with harshness due to a reduction in the number of trophic levels (Vermeij 1987). We therefore hypothesise that clade ranks are lower in harsh environments (whereas species richness is not affected).

Whatever the relationship between environmental harshness and clade rank, the existence of such a relationship requires that there is no trade-off between the capacity to use different types of harsh habitats; otherwise, the average harshness of the habitat used by any species would be intermediate (see Hoffmann \& Parsons, 1997 for possible mechanisms). The existence of a relationship between harshness and clade rank would also require that the use of harsh and mesic environments is phylogenetically conserved so that related species tend to have similar affinities to harsh and mesic environments (see Prinzing et al., 2001, phylogenetic signal sensu Losos, 2008). Without such conservatism, past patterns of speciation and extinction in ancestral environments would not be transmitted to distributions 
of clade ranks in present-day environments (Condamine et al., 2012). However, certain authors suggest that the capacity to use harsh environments can evolve and disappear rapidly (see Hoffmann \& Parsons, 1997 and Hoffmann \& Willi, 2008 for mechanisms), particularly if expansions and constrictions of such harsh environments may trigger the acquisition or loss of the capacity to use these environments (Gaston, 1998) and if the use of harsh environments imposes a cost (but see Gaston, 2003).We hence hypothesise that the use of harsh habitats is not constrained by a trade-off between different types of harshness and is phylogenetically conserved.

Should particular environments maintain low-clade-rank species and particular regions maintain these particular environments and their inhabitants, we would expect to observe that these regions also maintain many low-clade-rank species (see also Donoghue, 2008). We can speculate that selection might have favoured the use of harsh habitats far from the tropics (Jablonski, 2008), especially in the Northern Hemisphere, where a steep latitudinal gradient of decreasing biodiversity can be observed today (Chown et al., 2004). Given that the clade rank of a species reflects the outcome of millions of years of evolutionary history, the past differentiation of regions, notably the distinction between Laurasia and Gondwana, might be more important than their present-day configuration. One might speculate that past environments were harsher, on average, in Laurasia than in Gondwana (Vršanský, 2005; Crisp et al., 2010), reflecting, among other differences, the larger surface area of the landmasses in northern compared to southern temperate regions. Larger landmass would produce more climatic and thereby edaphic extremes in Laurasia and its descendent land masses than in Gondwana, except for Antarctica (Chown et al., 2004). Additionally, even restricted periods of harsh conditions might leave a strong signal in a continental fauna if the vast majority of the continent became harsh and later recolonisation was slow. This regional origin and maintenance of species might still be reflected by a larger number of low-clade-rank species 
132 in landmasses stemming from Laurasia (centres of origin, Myers \& Giller, 1988). Moreover,

133 independent of the above speculations, given what we know of the present worldwide

134 distribution of soils (FAO-UNESCO, 2007), climates (World Climate Map, 2012) and human

135 activities, harsh environments (e.g., soil acidity, drought, frost, waterlogging, heavy metal

136 contamination), with the exception of seashore salinity, appear to be more widely distributed

137 in ex-Laurasian than in ex-Gondwanan continents. Whatever the precise causes, we can

138 hypothesise that non-tropical regions and those of Laurasian origin harbour more low-clade-

139 rank species, largely as a consequence of the increased numbers of species using harsh

140 habitats.

The predictions derived from these hypotheses can be tested across extant species

142 belonging to monophyletic lineages that are ancient (having survived several ecological crises

143 and dating back to the Laurasia/Gondwana epochs), highly diversified and distributed

144 worldwide. Collembola (springtails) are one such old, diversified lineage dating back to the

145 Early Devonian (Hirst \& Maulik, 1926; Greenslade \& Whalley, 1986; Grimaldi, 2010), and

146 most actual forms, at the family or even genus level, are known from the Cretaceous

147 (Christiansen \& Pyke, 2002a, b). Among the cladistic studies conducted on Collembola, the

148 genus Willemia deserves special attention given its wide distribution from both an ecological

149 and a biogeographical point of view. The genus is monophyletic and comprises a large

150 number of species for which phylogenetic trees can be reconstructed unambiguously

151 (D’Haese \& Weiner, 1998; D’Haese, 1998, 2000 for subtrees of the genus). In addition,

152 certain species of Willemia are known for their preferential use of arid (Thibaud \& Massoud,

153 1988), polar (Sørensen et al., 2006), mountainous (Loranger et al., 2001), acidic (Ponge,

154 1993), saline (D’Haese, 2000), or polluted (Filser \& Hölscher, 1997) environments. The

155 genus is also representative of many others in the absence of a time-calibrated phylogeny due 156 to the scarcity of fossil records. This lack of information renders approaches based on branch 
157 length inapplicable but does not affect approaches based on clade ranks. Obviously, Willemia

158 is only one out of an almost infinite number of genera. However, studying one genus may

159 help to develop a methodological approach for teasing apart the associations between the use

160 of harsh environments and patterns of diversification within a phylogenetic context. This

161 approach may then be applicable to other genera and larger taxonomic units.

To evaluate the relationship between the use of harsh environments and clade rank, we tested whether (i) the use of different types of harsh environment is positively rather than negatively correlated (i.e., species tend to be able to tolerate either a broad range of harsh environments or none) and is phylogenetically conserved in the sense of being more similar among phylogenetically closely related species than among more distantly related species; and (ii) species using harsh habitats consistently occupy low clade ranks rather than being randomly scattered across the phylogeny, and these harsh environments tend to be the ancestral environments of such low-clade-rank species, which are as numerous as species absent from such harsh environments. To evaluate the relationship between geographic region, use of harsh environments and clade rank, we tested whether species outside the tropics occupy lower clade ranks than species within the tropics, due to a tendency of nontropical species to use harsher habitats. We also tested whether species on former Laurasian

174 land masses occupy lower clade ranks than species on former Gondwanan land masses, due to 175 a tendency to use harsher habitats. In all analyses we accounted for the statistical nonindependence of species. We also conducted character mapping to reconstruct ancestral stages and explore whether the environments and regions used by species are indeed ancestral to the respective (sub)lineage and hence might have influenced the clade rank of the respective species in that (sub)lineage. 
180

\section{MATERIALS AND METHODS}

\section{The genus Willemia and the reconstruction of its phylogeny}

Within the Class Collembola, the genus Willemia belongs to the Hypogastruridae family. It differs from other hypogastrurid genera by the total lack of pigment or furcula and the small size of the slender body, which never exceeds $1 \mathrm{~mm}$ in length (Thibaud, 2004). According to their life form, all Willemia species belong to the euedaphobiont sub-category Bc3b (small size, slender body, no furcula) of Rusek (2007). The study addresses 42 of the 43 species currently known worldwide in this genus (list in Appendix S1b). The absent species was only described in 2011 by D'Haese \& Thibaud, so its environmental or geographic distribution is still very far from being sufficiently documented. The genus is distributed worldwide, with 15 species recorded only in the tropics, 25 species outside the tropics and only 2 species present both in the tropics and elsewhere (details about the biogeographic distribution of species in Appendix S2e). A total of 13 species were recorded from continents and islands of

Gondwanan origin vs. 20 of Laurasian origin and 9 of uncertain origin (Appendix S2e). As for most Collembola, dispersal modes are still unknown, although sea currents have been suspected to favour long-distance transport (Thibaud, 2007). Willemia species live in the soil (from litter to mineral soil, whether acid or alkaline), in psammic environments (beaches, sand dunes, deserts) and in caves, but not all of them are found in harsh environments (Table 1). Overall, the great variation in the biogeographic and ecological distributions of species, together with a sufficient but still-manageable number of species, makes this genus a good model for testing hypotheses about relationships between biogeography, ecology and the evolution of extant species.

The reconstruction of the phylogeny of the genus Willemia is explained in Appendix S1a-d. This reconstruction confirmed the monophyly of the genus already established by 
D'Haese (2000). We were constrained to use morphological characters, as explained and justified in Appendix S1a. Obviously, speciation may not always leave morphological traces, and such "cryptic" speciation is overlooked if morphological characters alone are considered. This outcome is especially probable in lineages with morphological characters that are few in number or unstable in terms of shape and/or position (among Collembola, e.g., genera Folsomia and Parisotoma). Willemia, however, has numerous characteristics (e.g., hairs, sensilla, vesicles) of stable shape and position. Due to this feature of the genus, speciation is unlikely to be cryptic in Willemia. Cryptic speciation may be more frequent at the population level, but such ephemeral population phenomena were not of interest in our study. We also note that a dated phylogeny is not feasible for Willemia given the lack of dating points caused by the absence of fossils for this genus.

All analyses were run on each of the 6 most parcimonious phylogenetic trees as well as on a strict-consensus of 6 phylogenetic trees (detailed in Appendix S1: Phylogenetic reconstruction). The results from analyses run on the strict consensus tree are given in te Results section, those from the 6 indiviudal trees in the corresponding appendices (detailed in Appendix S3: Reconstruction of ancestral states)

\section{Use of harsh environments and the biogeographic distribution of Willemia species}

The use of harsh environments (as defined in the Introduction) was indicated by the occurrence of Willemia species in environments known for at least one factor that is thought to be a major constraint for most soil-dwelling organisms (see Hopkin, 1997 for springtails): i.e., xeric, hydric, arctic, alpine, acidic, metallic or saline soils. See Appendix S2a for detailed definitions of these factors and literature research methods and Appendix S2b for references. A 'harshness breadth' index was estimated for every species based on the number of harsh 
environments in which the species was recorded, scaled from 0 (no harsh environments recorded for the species) to 7 (all harsh environments recorded).

Biogeographic distributions were categorised as $(i)$ tropical (between the tropic latitudes, Inter-Tropical Convergence Zone, ITCZ) or non-tropical (north or south of the tropic latitudes) and as (ii) Gondwanan or Laurasian following the maps by Christiansen \& Bellinger (1995), as detailed in Appendix S2e. Appendix S2e also outlines the relationships between tropical/non-tropical and Laurasia/Gondwana classifications and between regions and harshness.

\section{Statistical Analyses}

The correlation among uses of different types of harsh environments across lineages was analysed by a phylogenetic Principal components analysis (pPCA), a multivariate method recently devised by Jombart et al. (2010b) by extending a methodology developed in spatial ecology and spatial genetics to the analysis of phylogenetic structures in biological features of taxa.

Phylogenetic conservatism is the tendency of closely related species to share similar values for a given trait (typically more similar than distantly related species, Wiens et al., 2010). We predicted phylogenetic conservation of the use of harsh environments, i.e., that related species tend to have similar harshness breadth index values. Here, harshness breadth varied from 0 to 7 harsh environments as defined above. Phylogenetic conservatism for harshness breadth was tested with the Pavoine et al. (2010) approach. Briefly, the total trait diversity of the lineage was decomposed across the nodes of a phylogenetic tree by attributing to each node a value measuring the differences among lineages descending from that node weighted by the proportion of species descending from it. Permutation tests (999 replicates) 
252 allowed the attribution of a probability to the observed value. Our principal test was the root-

253 skewness test, which verifies whether phylogenetic distances between species correspond to

254 distances in a given trait. Supplementary tests in Pavoine et al. (2010) explore whether trait

255 variation is concentrated on a single node or on a few nodes, but that work cannot be

256 presented in detail here (usually, the former were not significant, whereas the latter were).

257 Phylogenetic distances were measured as nodal distances, i.e., the number of nodes on the

258 shortest path that connects two species on the phylogenetic tree. For measuring distances

259 between species in terms of habitat harshness (a multi-choice variable), we used the simple

260 matching coefficient (Sokal \& Michener, 1958): $(a+b) /(a+b+c+d)$, where ' $a$ ' is the number of

261 harshness types in common, 'b' is the number of harshness types with which neither of the

262 species are associated, and 'c' and ' $d$ ' are the numbers of harshness types unique to each of

263 the two species.

Losos (2008) has suggested that the term 'phylogenetic conservatism' should only be used if trait change along the phylogeny is slower than Brownian motion and that the term 'phylogenetic signal' should be used for the wider phenomenon of correlations between trait distance and phylogenetic distance. However, properly identifying the rate of trait change would require a dated phylogeny, which is not feasible for Collembola. Moreover, whereas change in the use of harsh environments may be considered 'random' and not 'conservative' from the point of view of phylogenetic reconstruction, it is still much more 'conservative' than the changes in the harshness of the environment surrounding the animals. For simplicity, we therefore retain the term 'conservatism' and use it in the sense of a pattern, not of a process (see Wiens et al., 2010 for further discussion on phylogenetic conservatism). 
geographic correlates of clade ranks of species is vulnerable to the phylogenetic nonindependence of species. A classical approach to the problem of phylogenetic nonindependence is the use of sister-clade comparisons (Felsenstein, 1985), but this approach is not applicable in our case because sister clades have the same clade ranks by definition. An alternative and more general approach is to include co-matrices of phylogenetic proximity in a phylogenetic generalised least square fit (PGLS) as described in Martins \& Hansen (1997), using the method of Grafen (1989) to estimate branch lengths. To increase the symmetry of the harshness breadth distribution, this variable was square-root transformed.

We tested the relationships between the phylogenetic clade ranks of species as the dependent variable and either the species' tropical/non-tropical classification or their Gondwana/Laurasia classification as the independent variable. We conducted alternative analyses, either incorporating the uses of harsh habitats as covariables or not incorporating these uses. As the dependent variable was directly inferred from the species' phylogenetic position and was, thus, a characteristic of the phylogeny, we incorporated phylogenetic nonindependence in the explanatory variables as follows. We computed the F-statistic associated with each variable using an ordinary linear model. We then estimated a theoretical distribution of this statistic via the method of phylogenetic permutation described by Lapointe \& Garland (2001, see also Harmon \& Glor, 2010): closely related species are more likely to exchange values than more distantly related species. The values of the explanatory variables were permuted (999 times) by this approach, keeping the phylogenetic clade rank unchanged. The P-value was then calculated as the proportion of theoretical values of the F-statistic that were higher than or equal to the observed value. We note that species that occurred in both the Laurasia and Gondwana biogeographic domains (6 species) or were on continents or islands of uncertain origin ( 3 species) and species that were recorded both within and outside the tropics (2 species) were discarded from geographic analyses. 
All these methods were implemented in R (R Development Core Team, 2010), which

303 was used for all statistical calculations. The packages used were ade4 (Dray \& Dufour, 2007),

304 adephylo (Jombart et al., 2010a), ape (Paradis et al., 2004), and nlme (Pinheiro et al., 2010).

305 The $\mathrm{R}$ codes are available upon request.

$306 \quad$ For character mapping, we used Mesquite (Maddison \& Maddison, 2011);

307 specifically, we used parsimony and stochastic character mapping. As both approaches

308 produced the same results, we only present the parsimony mapping, which suffers less from

309 the absence of biogeographic classifications for individual species. 


\section{RESULTS}

The characters and phylogeny of Willemia are provided in Appendix S1b and Appendix S1d, respectively. Note that there is no phylogenetic structure in the study intensity of Willemia species (i.e., the numbers of references), and hence, the analyses presented below are not biased by study intensity (Appendix S2c). Although branch lengths are not available, as explained in the Introduction, there is a major variation in the clade rank of species, ranging from 2 to 13, reflecting substantial variation in the number of extant close relatives across species.

\section{Uses of most types of harsh habitats are positively correlated}

The phylogenetic principal components analysis (pPCA) indicated strong positive correlations between all types of harsh habitats with the exception of salinity. The use of all other types of harsh habitats showed clear positive scores on the same principal component axis (Fig. 1). A visual examination of Table 1 (where species are arranged according to their order in the phylogenetic tree) confirms this result: with the exception of salinity, the use of all types of harsh habitats appears to be phylogenetically positively correlated. Given that the use of saline habitats corresponded to the absence of all of the other six types of harsh habitats, we excluded salinity from further analyses to better capture the overall syndrome of harsh habitat use (see also Appendix S2d).

\section{Phylogenetic conservatism in the use of harsh habitats}

The types of harshness under which species were found exhibited clear phylogenetic conservatism (root-skewness test $\mathrm{P}=0.002$ ). Additionally, the number of types of harsh 
habitats used by a species (harshness breadth) was phylogenetically conserved (root-skewness test; $\mathrm{P}=0.042$ ). If salinity was excluded from the array of harsh habitats (given that it is not positively related to other harshness factors, see above), a stronger conservatism of harshness breadth was found (root-skewness test $\mathrm{P}=0.013$ ). The presence/absence of Willemia species in harsh habitats (rather than the number of harsh habitats used) exhibited an even clearer phylogenetic conservatism if salinity was excluded from the array of harsh habitats (rootskewness test $\mathrm{P}=0.001)$. This phylogenetic structure was confirmed using parsimony character state reconstruction (Fig. 2 a). These results are based on the consensus tree but are robust to phylogenetic uncertainty and were found in all 6 of the equally parsimonious trees (Appendix S3).

\section{Species using harsh habitats have lower clade ranks but are as numerous as species} using mesic habitats

We found that the clade rank of a species decreased with the species' harshness breadth (PGLS; $\mathrm{P}=0.002$ ). If salinity was excluded, it appeared that the distance to the root of the phylogenetic tree was quite similar for all species using harsh habitats independently of the number of harsh habitat types they were using, with all harshness-tolerant species occupying a basal position (Fig. 3). The ancestral nature of life in harsh habitats was also visually assessed through parsimony character state reconstruction (Fig. 1 a), mapping the use of harsh habitats (salinity excluded) and other habitats on the cladogram. Most of the 22 harshness-tolerant species were located close to the root, i.e., they corresponded to a "basal" pool of species including all species from W. multilobata to W. denisi in Fig. 1 a. Only three species in this group did not confirm that harshness tolerance was an ancestral character: W. bellingeri, $W$. psammophila and $W$. unispina. Species belonging to the most advanced group, in contrast, 
were not found in harsh habitats (except for saline habitats) with the exception of $W$. nepalensis. All these results are based on the consensus tree but are robust to phylogenetic uncertainty and were found in all 6 of the equally parsimonious trees (Appendix S3).

In total, there were 22 species using harsh habitats and 20 species using only mesic habitats (i.e., species that were never recorded in any of the harsh habitat types considered except salinity). This result is not significantly different from equality $\left(\mathrm{df}=1\right.$; $\mathrm{Chi}^{2}=0.095$; $\mathrm{P}=0.758)$.

\section{Geographical distribution: species using harsh habitats tend to be Laurasian, and as a} statistical consequence, Laurasians tend to have low clade ranks

We found that species using harsh and mesic habitats were distributed differently across the globe. Species using harsh habitats tended to occur in non-tropical regions, although the relationship was relatively weak (Fig. 4a; PGLS; $\mathrm{df}=30 ; \mathrm{t}=2.29 ; \mathrm{P}=0.029$ ). At the same time, species using harsh habitats were strongly restricted to regions of Laurasian origin (Fig. 4b; PGLS; $\mathrm{df}=30 ; \mathrm{t}=3.19 ; \mathrm{P}=0.003)$. In fact, only two harshness-tolerant species were recorded outside former Laurasia (W. trilobata and W. namibiae, Appendix S2e). These results are based on the consensus tree but are robust to phylogenetic uncertainty and were found in all 6 of the equally parsimonious trees (Appendix S3).

Low-clade-rank species were strongly restricted to present non-tropical regions (Fig. $5 \mathrm{a} ; \mathrm{n}=31$ as in all tests of this paragraph, tests based on phylogenetic permutations, $\mathrm{F}=26.14$ : $\mathrm{P}=0.001$, and see character state reconstruction, Fig. 1b). This relationship was maintained if harshness breadth was included as a co-variable: harshness breadth and presence in presentday non-tropical regions were both related to low clade rank $(\mathrm{F}=23.90 ; \mathrm{P}=0.001$ for harshness breadth, and $\mathrm{F}=9.76 ; \mathrm{P}=0.007$ for presence in present-day non-tropical regions; conclusions 
were not impacted by the order in which the two explanatory variables were entered in the model; harhness first: $\mathrm{F}=29.17 ; \mathrm{P}=0.001$, harshness second: $\mathrm{F}=4.48 ; \mathrm{P}=0.048)$. Therefore, the high harshness tolerance of non-tropical species did not explain their low clade rank. Species of low clade rank also tended to be restricted to former Laurasia regions (Fig. 5b; $F=10.47$; $\mathrm{P}=0.006$ and see character state reconstruction, Fig. 1c). If occurrence in former Laurasia was included first in the model and harshness breadth second, both variables were significant $(\mathrm{F}=12.68 ; \mathrm{P}=0.002$ for occurrence in former Laurasia and $\mathrm{F}=7.33 ; \mathrm{P}=0.014$ for harshness breadth). However, this relationship disappeared if harshness breadth was added to the model first: in this case, occurrence in former Laurasia was no longer significant $(\mathrm{F}=1.31 ; \mathrm{P}=0.262)$, whereas harshness breadth was still significantly related to low clade rank $(\mathrm{F}=18.69$; $\mathrm{P}=0.001)$. Overall, this result indicates that species using harsh environments are particularly bound to former Laurasia continents (above paragraph) and that — as a statistical consequence — we find many species of low clade rank on former Laurasia continents. All these results are based on the consensus tree but are robust to phylogenetic uncertainty and were found in all 6 of the equally parsimonious trees (Appendix S3).

\section{DISCUSSION}

We found that uses of different types of harsh environments are maintained among close relatives and have similar phylogenetic signals with the exception of use of saline habitats. Use of saline habitats is thus not consistent with our hypotheses (see Introduction) and was excluded from further analyses. There are two opposing lines of explanation for this exception. First, one can argue that tolerance of saline conditions comes with a major cost in terms of tolerance of multiple other harshness factors, and thus, salinity tolerance will not increase the overall capacity to use harsh environments and will be lost rapidly through 
evolution if no longer needed. Second, there are putative arguments suggesting that salinity is not a form of harshness from the point of view of Collembola (Appendix S2d). Pending more ecophysiological studies on the tolerance of springtails to sea water, it might be suggested that life in contact with dilute saline solutions (seashores but not dry saline environments) requires no special adaptation in basal Hexapoda, in contrast to fully terrestrial insects (higher insects).

Using a phylogenetic framework, we showed that among Willemia springtail species, the use of harsh habitats (tolerance of harshness) displayed a strong pattern of phylogenetic conservatism and no phylogenetic trade-off in the capacity to use different types of harsh habitat (except for salinity, see Appendix S2d). These results ultimately suggest that the use of harsh habitats can affect the mode of diversification of these lineages and, thereby, the distribution of clade ranks across habitats and eventually regions. In fact, we found that species using harsh habitats have significantly lower clade ranks.

Although the occurrence of archaic life forms has already been documented in specific exotic and harsh habitats such as volcanoes, hot springs, deserts and ice caps (Oliver et al., 2000; Nriagu, 2003; Labandeira, 2005; Oliver et al., 2005; Ehrhardt et al., 2007), a systematic link between species clade rank and habitat harshness has not, to our knowledge, been demonstrated previously. Lower clade ranks would be consistent with lower speciation rates in harsh habitats. However, we also found that species using harsh habitats are even slightly more numerous than species using mesic habitats. This combination of results is consistent with a scenario of decreased net extinction of species combined with decreased net speciation in harsh habitats. We stress, however, that we can only speculate on speciation and extinction averaged across time; we do not know whether this pattern reflects permanently low speciation rates combined with permanently low extinction rates or, for instance, initially high speciation and very low extinction rates combined with later very low speciation rates combined with high extinction rates. Both scenarios may produce the same low clade ranks of 
extant species. Independently of the precise mechanisms, harsh habitats function today as museums of low-clade-rank species, i.e., of species that are the last extant representatives of ancient lineages.

Such a pattern of conservatism and of the preferential presence of low-clade-rank species in harsh habitats may ultimately result in the global distribution of harsh-habitat species driving the global distribution of low-clade-rank species, as predicted. In fact, we found that species using harsh habitats exhibit distinct geographic distributions — they are more numerous outside the tropics and, in particular, on former Laurasia — and that species of low clade rank match these distributions. In addition, for Laurasia, the occurrence of lowclade-rank species is, in fact, explained by the occurrence of species in harsh habitats. For this reason, the geographically conserved use of harsh habitats decreases the phylogenetic clade rank of species on the continents of former Laurasia.

Our results contribute to the debate on the evolutionary fate of 'generalists' versus 'specialists'. Generalists are thought to be better able to overcome ecological crises (Raup, 1986; Zhou et al., 2005). More recently, however, Colles et al. (2009) showed that different phylogenetic approaches may lead to diverging conclusions. Our present phylogenetic study compares 'harshness generalists' to species putatively specialising in habitats lacking any of the harshness factors. The results are consistent with a longer survival of 'harshness generalists' and hence rather point towards generalists being, in fact, less susceptible to environmental change than specialists. However, our study also indicates that reduced extinction might possibly be coupled with reduced speciation, as this has been shown with other traits, e.g. geographic range (Parker et al., 1999), leaving practically no net effect on the numbers of species using harsh habitats. 
Our results point to a common factor of tolerance of environmental harshness, which would be shared by a pool of low-clade-rank species, as uses of different harsh habitats were positively correlated with one another. This result is not surprising in view of the roles of soil acidity, altitude and latitude: the biologically active part of the soil (the topsoil) becomes more acidic as the decomposition rate of organic matter decreases, leaving the organic matter humified rather than mineralised (Ulrich, 1986; Ponge, 2003, 2012). However, it was more surprising to find relationships between these three factors and drought or metallic pollution. The only point in common among these five factors appears to be a decrease in biological activity caused by harsh environmental conditions. To explain these positive relationships among different types of harshness tolerance, we should first examine the cellular level. The integrity of cell membranes, combined with active cellular repair, is known to protect a wide array of organisms from death caused by environmental hazards (Nriagu, 2003; Oliver et al., 2005; Shi et al., 2008; Timmermans et al., 2009). This feature could be the most primitive mechanism of harshness tolerance, requiring no specialised adaptation to any particular harshness factor but rather the coordinated expression of genes functioning in common in a 'general-purpose genotype' (Weider, 1993; Niehrs \& Pollet, 1999; Vohradsky et al., 2000; Van Doninck et al., 2002; Kaplan et al., 2004). For instance, it has been shown that drought acclimation produces cold tolerance in springtails (Holmstrup et al., 2002) and that long-chain fatty acids of phospholipidic membranes are involved in this phenomenon (Bayley et al., 2001). These findings are consistent with the evolutionary importance of membrane integrity (Jobson et al., 2010). Adaptation to harsh environments may occur rapidly if a phylogenetic lineage already possesses an efficient array of regulatory genes, known to be as evolutionarily important as changes in enzyme structures (Roelofs et al., 2006, 2010). However, the evolutionary acquisition of this gene array might be difficult and might only occur rarely. This 
hypothesis is consistent with our observation of only a few cases of independent acquisitions of the capacity to use harsh habitats.

We showed that derived species of high clade rank were primarily tropical species (while not all tropical species are derived), an observation also made for marine bivalves by Harnik et al. (2010). This result is in contrast to the tropical conservatism hypothesis of Wiens \& Donoghue (2004), which suggests that the tropics, representing supposedly more ancient environments, should harbour more ancient species characterised by low clade ranks (without excluding more recent species). Our results could be explained by a more ancient origin of environments observed today outside of the tropics, compared to today's tropical environments (Smith et al., 2007). However, across the lifetime of the Collembola lineage, the tropical environments are usually considered to be at least as old as the non-tropical ones (e.g., Behrensmeyer et al., 1992). Alternatively, our results can be explained if the low clade rank of species results from a trait such as the capacity to use harsh habitats and if species with this trait tend to occur outside rather than inside the tropics. However, we found that the tropical/clade-rank relationship was independent of the use of harsh habitats. The observed high clade ranks of tropical species therefore remain unexplained. Potentially, traits other than the use of harsh habitats need to be considered, as well as an interplay between environmental filters (mainly operating out of the tropics) and evolutionary potential of lineages (mainly operating in the tropics), as postulated by Harnik et al. (2010). We note, however, that most tropical species are found on territories of Gondwanan origin and that the high clade rank of Gondwanan species, in turn, could be explained by their present-day use of mesic habitats. Our results may thus point to a link between niche conservatism, diversification, and biogeographic distribution leading to patterns that are inconsistent with those predicted by Wiens \& Donoghue's (2004) tropical conservatism hypothesis. It remains to be tested whether 
the patterns we observed are a rare exception for a small group of species or can be found more frequently, e.g., in other groups of invertebrates.

By creating harsh environments (acid rain, polluted water, soil and atmosphere, vegetation-less areas) throughout the world and by accelerating species dispersal (alien introductions), humans select for particular major lineages to the detriment of others (Purvis, 2008; Ozinga et al., 2009; May, 2010). However, our results show that by rendering global environments increasingly harsh, humans also select for particular evolutionary scenarios to the detriment of others: increasingly abundant harsh environments appear to represent museum scenarios, i.e., environments that accumulate low-clade-rank species. It is possible that this outcome is due to low extinction and speciation rates. In contrast, environments of low harshness become rare and therefore potentially represent a cradle scenario, i.e., environments that accumulate high clade-rank species, due perhaps to high rates of speciation. Another result is that the use of harsh habitats is apparently a character that, in most cases, does not originate de novo when needed but is carried by particular species for very long periods of time. A high priority should thus be given to the conservation of this pool of lowclade-rank species. However, other studies are necessary to ascertain the generality of the patterns we discerned in one ancient animal group, Collembola. These studies should focus on other ancient but highly diversified groups, such as mites and mosses, which are suspected to be relatively tolerant of harsh environments (Prinzing et al., 2000; Oliver et al., 2005).

\section{ACKNOWLEDGEMENTS}

We acknowledge the work of countless collectors in the field and of the museum staff responsible for the collections, our discussions with Scot Wing and Conrad Labandeira and the technical support of Valerie Briand. AP profited from ATIP funding provided by the 
527 CNRS. Comments by Michael Angilletta, Marl McPeek and two anonymous reviewers

528 substantially improved the manuscript.

529

530 


\section{REFERENCES}

Bartish, I., Hennekens, S., Aidoud, A., Hennion, F. \& Prinzing, A. (2010) Species pools along contemporary environmental gradients represent different levels of diversification. Journal of Biogeography, 37, 2317-2331.

Bayley, M., Petersen, S.O., Knigge, T., Köhler, H.R. \& Holmstrup, M. (2001) Drought acclimation confers cold tolerance in the soil collembolan Folsomia candida. Journal of Insect Physiology, 47, 1197-1204.

Behrensmeyer, A.K., Damuth, J.D., Di Michele, W.A., Potts, R., Sues, H.D. \& Wing, S. (1992) Terrestrial ecosystems through time. Chicago University Press, Chicago.

Buckley, J., Bridle, J.R. \& Pomiankowski, A. (2010) Novel variation associated with species range expansion. BMC Evolutionary Biology, 10, 382.

Callaway, R.M., Brooker, R.W., Choler, P., Kikvidze, Z., Lortie, C.J., Michalet, R., Paolini, L., Pugnaire, F.I., Newingham, B., Aschehoug, E.T., Armas, C., Kikodze, D., Cook, B.J. (2002) Positive interactions among alpine plants increase with stress. Nature, 417, 844-848.

Chown, S.L. \& Gaston, K.J. (2000) Rapoport effect and speciation/extinction rates: reply. Trends in Ecology and Evolution, 15, 514-515.

Chown, S.L., Sinclair, B.J., Leinaas, H.P. \& Gaston, K.J. (2004) Hemispheric asymmetries in biodiversity: a serious matter for ecology. PLoS Biology, 2, e406.

Christiansen, K. \& Bellinger, P. (1995) The biogeography of Collembola. Polskie Pismo Entomologiczne, 64, 279-294. 
552 Christiansen, K., \& Pike, E. (2002a) A preliminary report on the Cretaceous Collembola. Pedobiologia, 46, 267-273.

Christiansen, K., \& Pike, E. (2002b) Cretaceous Collembola (Arthropoda, Hexapoda) from the Upper Cretaceous of Canada. Cretaceous Research, 23, 165-188.

Colles, A., Liow, L.H. \& Prinzing, A. (2009) Are specialists at risk under environmental change? Neoecological, paleoecological and phylogenetic approaches. Ecology Letters, 12, 849-863.

Condamine, F.L., Sperling, F.A.H., Wahlberg, N., Rasplus, J.Y. \& Kergoat, G.J. (2012) What causes latitudinal gradients in species diversity? Evolutionary processes and ecological constraints on swallowtail biodiversity. Ecology Letters, 15, 267-277.

Crisp, M.D., Isagi, Y., Kato, Y., Cook, L.G. \& Bowman, D.M.J.S. (2010) Livistona palms in Australia: ancient relics or opportunistic immigrants? Molecular Phylogenetics and Evolution, 54, 512-523.

D’Haese, C. (1998) Willemia anophthalma-group (Collembola: Hypogastruridae): systematic, new species, distribution and habitats. European Journal of Entomology, 95, 581-592.

D'Haese, C. (2000) Is psammophily an evolutionary dead end? A phylogenetic test in the genus Willemia (Collembola: Hypogastruridae). Cladistics, 16, 255-273.

D’Haese, C. \& Thibaud, J.M. (2011) Description and phylogenetic position of a new Willemia species (Collembola: Hypogastruridae) from the littoral coast of Brazil. Zootaxa, 2932, 33-40. 
572 D'Haese, C. \& Weiner, W.M. (1998) A review of Willemia buddenbrocki-group (Collembola,

573

574

575

576

577

578

579

580

581

582

583

584

585

586

587

588

589

590

591

592 Poduromorpha, Hypogastruridae) with cladistic analysis. Journal of Natural History, 32, 969-986.

Donoghue, M.J. (2008) A phylogenetic perspective on the distribution of plant diversity. Proceedings of the National Academy of Sciences of the United States of America, 105, Supplement 1, 11549-11555.

Dray, S. \& Dufour, A.B. (2007) The Ade4 package: implementing the duality diagram for ecologists. Journal of Statistical Software, 22, 1-20.

Ehrhardt, C.J., Haymon, R.M., Lamontagne, M.G. \& Holden, P.A. (2007) Evidence for hydrothermal Archaea within the basaltic flanks of the East Pacific Rise. Environmental Microbiology, 9, 900-912.

FAO-UNESCO. (2007) Digital Soil Map of the World version 3.6. Food and Agriculture Organization of the United Nations, Rome. Available at: http://www.fao.org/geonetwork/srv/en/metadata.show?id=14116.

Felsenstein, J. (1985) Phylogenies and the comparative method. American Naturalist, 125, 115.

Filser, J. \& Hölscher, G. (1997) Experimental studies on the reactions of Collembola to copper contamination. Pedobiologia, 41, 173-178.

Gaston, K.J. (1998) Species-range size distributions: products of speciation, extinction and transformation. Philosophical Transactions of theRoyal Society, Series B, Biological Sciences, 353, 219-230. 
593 Gaston, K.J. (2003) The structure and dynamics of geographic ranges. Oxford University 594 Press, Oxford.

595

Grafen, A. (1989) The phylogenetic regression. Philosophical Transactions of the Royal Society of London, Section B, Biological Sciences, 326, 119-157.

Greenslade, P. \& Whalley, P.E.S. (1986) The systematic position of Rhyniella praecursor Hirst \& Maulik (Collembola), the earliest known hexapod. Second International Seminar on Apterygota, Siena, Italy, September 4-6, 1986 (ed. by R. Dallai), pp. 319323. University of Siena, Siena.

Grimaldi, D.A. (2010) 400 million years on six legs: on the origin and early evolution of Hexapoda. Arthropod Structure and Development, 39, 191-203.

Grime, J.P. (1977) Evidence for the existence of three primary strategies in plants and its relevance to ecological and evolutionary theory. American Naturalist, 111,1169-1194.

Harmon, L.J. \& Glor, R.E. (2010) Poor statistical performance of the Mantel test in phylogenetic comparative analyses. Evolution, 64, 2173-2178.

Harnik, P.G., Jablonski, D., Krug, A.Z. \& Valentine, J.W. (2010) Genus age, provinvial area and the taxonomic structure of marine faunas. Proceedings of the Royal Society of London, Section B, Biological Sciences, 277, 3427-3435.

Hawkins, B.A., Diniz-Filho, J.A.F., Jaramillo, C.A. \& Soeller, S.A. (2007) Climate, niche conservatism, and the global bird diversity gradient. American Naturalist, 170, S16S27.

Hirst, S. \& Maulik, S. (1926) On some Arthropod remains from the Rhynie Chert (Old Red Sandstone). Geological Magazine, 63, 69-71. 
615 Hoffmann, A.A. \& Parsons, P.A. (1997) Extreme environmental change and evolution. $616 \quad$ Cambridge University Press, Cambridge.

617 Hoffmann, A.A. \& Willi, Y. (2008) Detecting genetic responses to environmental changes. Nature Reviews Genetics, 9, 421-432.

Holmstrup, M., Hedlund, K. \& Boriss, H. (2002) Drought acclimation and lipid composition in Folsomia candida: implications for cold shock, heat shock and acute desiccation stress. Journal of Insect Physiology, 48, 961-970.

Hopkin, S.P. (1997) Biology of the springtails. Oxford University Press, Oxford.

Jablonski, D. (1993) The tropics as a source of evolutionary novelty through geological time. Nature, 364, 142-144.

Jablonski, D. (1999) The future of the fossil record. Science, 284, 2114-2116.

Jablonski, D. (2008) Extinction and the spatial dynamics of biodiversity. Proceedings of the National Academy of Sciences of the United States of America, 105, 11528-11535.

Jablonski, D., Roy, K. \& Valentine, J.W. (2006) Out of the tropics: evolutionary dynamics of the latitudinal diversity gradient. Science, 314, 102-106.

Jobson, R.W., Nabholz, B. \& Galtier, N. (2010) An evolutionary genome scan for longevityrelated natural selection in mammals. Molecular Biology and Evolution, 27, 840-847.

Jombart, T., Balloux, F. \& Dray, S. (2010a) Adephylo: new tools for investigating the phylogenetic signal in biological traits. Bioinformatics, 26, 1907-1909.

Jombart, T., Pavoine, S., Devillard, S. \& Pontier, D. (2010b) Putting phylogeny into the analysis of biological traits: a methodological approach. Journal of Theoretical Biology, 264, 693-701. 
637 Kaplan, F., Kopka, J., Haskell, D.W., Zhao, W., Schiller, K.C., Gatzke, N., Sung, D.Y. \&

638

639

640

641

642

643

644

645

646

647

648

649

650

651

652

653

654

655

656

657 Guy, C.L. (2004) Exploring the temperature-stress metabolome of Arabidopsis. Plant Physiology, 136, 4159-4168.

Labandeira, C.C. (2005) Invasion of the continents: cyanobacterial crusts to tree-inhabiting arthropods. Trends in Ecology and Evolution, 20, 253-262.

Lapointe, F.J. \& Garland, T. (2001) A generalized permutation model for the analysis of cross-species data. Journal of Classification, 18, 109-127.

Loranger, G., Bandyopadhyaya, I., Razaka, B. \& Ponge, J.F. (2001) Does soil acidity explain altitudinal sequences in collembolan communities? Soil Biology and Biochemistry, 33, 381-393.

Losos, J.B. (2008) Phylogenetic niche conservatism, phylogenetic signal and the relationship between phylogenetic relatedness and ecological similarity among species. Ecology, Letters, 11, 995-1003.

Maddison, W.P. \& Maddison, D.R. (2011) Mesquite: a modular system for evolutionary analysis. Version 2.75. University of British Columbia, Vancouver, and Oregon State University, Portland.

Martins, E.P. \& Hansen, T.F. (1997) Phylogenies and the comparative method: a general approach to incorporating phylogenetic information into the analysis of interspecific data. American Naturalist, 149, 646-667.

May, R.M. (2010) Ecological science and tomorrow's world. Philosophical Transactions of the Royal Society of London, Section B, Biological Sciences, 365, 41-47. 
658 Myers, A.A. \& Giller, P.S. (1988) Analytical biogeography: An integrated approach to the 659 study of animal and plant distributions. Chapman and Hall, London.

660 Niehrs, C. \& Pollet, N. (1999) Synexpression groups in eukaryotes. Nature, 402, 483-487.

661 Nriagu, J. (2003) Heavy metals and the origin of life. Journal of Physics IV, 107, 969-974.

662 Oliver, M.J., Tuba, Z. \& Mishler, B.D. (2000) The evolution of vegetative desiccation 663 tolerance in land plants. Plant Ecology, 151, 85-100.

664

665

666

667

668

669

670

671

672

673

674

675

676

677

Oliver, M.J., Velten, J. \& Mishler, B.D. (2005) Desiccation tolerance in Bryophytes: a reflection of the primitive strategy for plant survival in dehydrating habitats? Integrative and Comparative Biology, 45, 788-799.

Ozinga, W.A., Römermann, C., Bakker, R.M., Prinzing, A., Tamis, W.L.M., Schaminée, J.H.J., Hennekens, S.M., Thompson, K., Poschlod, P., Kleyer, M., Bakker, J.P. \& Van Groenendael, J. M. (2009) Dispersal failure contributes to plant losses in NW Europe. Ecology Letters, 12, 66-74.

Paradis, E., Claude, J. \& Strimmer K. (2004) APE: analyses of phylogenetics and evolution in R language. Bioinformatics, 20, 289-290.

Parker, W.C., Feldman, A. \& Arnold, A.J. (1999) Paleobiogeographic patterns in the morphologic diversification of the Neogene planktonic foraminifera. Palaeogeography, Palaeoclimatology, Palaeoecology, 152, 1-14.

Pavoine, S., Baguette, M. \& Bonsall, M.B. (2010) Decomposition of trait diversity among the nodes of a phylogenetic tree. Ecological Monographs, 80, 485-507. 
678 Pinheiro, J., Bates, D., Deb Roy, S., Sarkar, D. \& the R Development Core Team. (2010)

679

680

681

682

683

684

685

686

687

688

689

690

691

692

693

694

695

696

697

698

699 NLME: Linear and Nonlinear Mixed Effects Models. $R$ package version 3.1-97. $\mathrm{R}$ Foundation for Statistical Computing, Vienna.

Ponge, J.F. (1993) Biocenoses of Collembola in atlantic temperate grass-woodland ecosystems. Pedobiologia, 37, 223-244.

Ponge, J.F. (2003) Humus forms in terrestrial ecosystems: a framework to biodiversity. Soil Biology and Biochemistry, 35, 935-945.

Ponge, J.F. (2012) Plant-soil feedbacks mediated by humus forms: a review. Soil Biology and Biochemistry (in press).

Prinzing, A., Durka, W., Klotz, S. \& Brandl, R. (2001) The niche of higher plants: evidence for phylogenetic conservatism. Proceedings of the Royal Society of London, Section B, Biological Sciences, 268, 2383-2389.

Prinzing, A., Kretzler, S. \& Beck, L. (2000) Resistance to disturbance is a diverse phenomenon and does not increase with abundance: the case of oribatid mites. Écoscience, 7, 452-460.

Prinzing, A., Ozinga, W.A. \& Durka, W. (2004) The relationship between global and regional distribution diminishes among phylogenetically basal species. Evolution, 58, 26222633.

Purvis, A. (2008) Phylogenetic approaches to the study of extinction. Annual Review of Ecology, Evolution and Systematics, 39, 301-319.

Purvis, A., Agapow, P.M., Gittleman, J.L. \& Mace, G.M. (2000) Nonrandom extinction and the loss of evolutionary history. Science, $\mathbf{2 8 8}, 328-330$. 
Raup, D.M. (1986) Biological extinction in Earth history. Science, 231, 1528-1533.

R Development Core Team. (2010) $R$ : a language and environment for statistical computing. R Foundation for Statistical Computing, Vienna.

Roelofs, D., Morgan, J. \& Stürzenbaum, S. 2010. The significance of genome-wide transcriptional regulation in the evolution of stress tolerance. Evolutionary Ecology, 24, 527-539.

Roelofs, D., Overhein, L., de Boer, M.E., Janssens, T.K.S. \& Van Straalen, N.M. (2006) Additive genetic variation of transcriptional regulation: metallothionein expression in the soil insect Orchesella cincta. Heredity, 96, 85-92.

Rusek, J. (2007) A new classification of Collembola and Protura life forms. Contributions to soil zoology in Central Europe II (ed. by K. Tajovský, J. Schlaghamerský and V. Pižl), pp. 109-115. Institute of Soil Zoology, Biology Centre, Academy of Sciences of the Czech Republic, České Budějovice.

Shi, Y., An, L., Zhang, M., Huang, C., Zhang, H. \& Xu, S. (2008) Regulation of the plasma membrane during exposure to low temperatures in suspension-cultured cells from a cryophyte (Chorispora bungeana). Protoplasma, 232, 173-181.

Smith, S.A., Nieto Montes de Oca, A., Reeder, T.W. \& Wiens J. (2007) A phylogenetic perspective on elevational species richness patterns in Middle American treefrogs: why so few species in lowland tropical rainforests? Evolution, 61, 1188-1207.

Sokal, R.R. \& Michener, C.D. (1958) A Statistical method for evaluating systematic relationships. University of Kansas Scientific Bulletin, 38, 1409-1438. 
Sørensen, L.I., Holmstrup, M., Maraldo, K., Christensen, S. \& Christensen, B. (2006.)Soil fauna communities and microbial respiration in high Arctic tundra soils at Zackenberg, Northeast Greenland. Polar Biology, 29, 189-195.

Thibaud, J.M. (2004). Synopses on Palaearctic Collembola, Volume 4, Hypogastruridae. Sttaliches Museum für naturkunde, Görlitz.

Thibaud, J.M. (2007) Recent advances and synthesis in biodiversity and biogeography of arenicolous Collembola. Annales de la Société Entomologique de France, 43, 181185.

Thibaud, J.M. \& Massoud Z. (1988) Recherche sur la faune interstitielle aérienne des sables fins: les collemboles. II. Désert de Namibie. Annales de la Société Entomologique de France, 24, 211-214.

Timmermans, M.J.T.N., Roelofs, D., Nota, B., Ylstra, B. \& Holmstrup, M. (2009) Sugar sweet springtails: on the transcriptional response of Folsomia candida (Collembola) to desiccation stress. Insect Molecular Biology, 18, 737-746.

Ulrich, B. (1986) Natural and anthropogenic components of soil acidification. Zeitschrift für Pflanzenernährung und Bodenkunde, 149, 702-717.

Van Doninck, K., Schön, I., De Bruyn, L. \& Martens, K. (2002) A general purpose genotype in an ancient asexual. Oecologia, 132, 205-212.

Vermeij, G.J. (1987) Evolution and escalation: an ecological history of life. Princeton University Press, Princeton.

Vohradsky, J., Li, X.M., Dale, G., Folcher, M., Nguyen, L., Viollier, P.H. \& Thompson, C.J. (2000) Developmental control of stress stimulons in Streptomyces coelicolor revealed 
by statistical analyses of global gene expression patterns. Journal of Bacteriology, 182, 4979-4986.

Vršanský, P. (2005) Mass mutations of insects at the Jurassic/Cretaceous boundary? Geologica Carpathica, 56, 473-481.

Weider, L.J. (1993) A test of the general-purpose genotype hypothesis: differential tolerance to thermal and salinity stress among Daphnia clones. Evolution, 47, 965-969.

Wiens, J.J. \& Donoghue, M.J. (2004) Historical biogeography, ecology, and species richness. Trends in Ecology and Evolution, 19, 639-644.

Wiens, J.J., Ackerly, D.D., Allen, A.P., Anacker, B.L., Buckley, L.B., Cornell, H.V., Damschen, E.I., Davies, T.J., Grytnes, J.A., Harrison, S.P., Hawkins, B.A., Holt, R.D., McCain, C.M. \& Stephens, P.R. (2010) Niche conservatism as an emerging principle in ecology and conservation biology. Ecology Letters, 13, 1310-1324.

Willis, J.C. (1922) Age and area. A study in geographical distribution and origin of species. Cambridge University Press, Cambridge.

World Climate Map. (2012) Available at http://www.mapsofworld.com/world-maps/worldclimate-map.html.

Zhou, T., Carlson, J.M. \& Doyle, J. (2005) Evolutionary dynamics and highly optimized tolerance. Journal of Theoretical Biology, 236, 438-447. 


\section{SUPPORTING INFORMATION}

Appendix S1 Phylogenetic reconstruction

765

Appendix S2 Literature research: definitions, references, exploration of biases

766

Appendix S3 Robustness of the analysis to variation in underlying phylogenetic trees

767

768

\section{BIOSKETCH}

769 Andreas Prinzing studies the interface of habitat environments, past evolutionary

770 diversification of species pools, and how this diversification controls, and is maintained by,

771 present ecological interactions.

772 Author contributions: JFP and AP conceived the ideas with the collaboration of all other

773 authors, JFP collected the data, CDH constructed the phylogeny, SP analysed the data, and

774 JFP and AP took the lead role in the writing.

775

776 Editor: Melodie McGeoch 
Table 1. Use of harsh environments by Willemia species according to literature (references listed in Electronic Appendix S2). See text for more details on stress factors.

\begin{tabular}{|c|c|c|c|c|c|c|c|c|c|}
\hline & Xeric & Hydric & Arctic & Alpine & Acid & Metallic & Saline & $\begin{array}{l}\text { Tolerance } \\
\text { breadth } \\
\text { (salinity } \\
\text { included) }\end{array}$ & $\begin{array}{l}\text { Tolerance } \\
\text { breadth } \\
\text { (salinity } \\
\text { excluded) }\end{array}$ \\
\hline W. multilobata & $\sqrt{ }$ & & $\sqrt{ }$ & $\sqrt{ }$ & $\sqrt{ }$ & & $\sqrt{ }$ & 5 & 4 \\
\hline W. bellingeri & & & & & & & $\sqrt{ }$ & 1 & 0 \\
\hline W. trilobata & $\sqrt{ }$ & & & & & & & 1 & 1 \\
\hline W. namibiae & $\sqrt{ }$ & & & & & & & 1 & 1 \\
\hline W. similis & $\sqrt{ }$ & & $\sqrt{ }$ & $\sqrt{ }$ & $\sqrt{ }$ & & & 4 & 4 \\
\hline W. christianseni & & & & $\sqrt{ }$ & $\sqrt{ }$ & & & 2 & 2 \\
\hline W. anophthalma & $\sqrt{ }$ & $\sqrt{ }$ & $\sqrt{ }$ & $\sqrt{ }$ & $\sqrt{ }$ & $\sqrt{ }$ & & 6 & 6 \\
\hline W. dubia & $\sqrt{ }$ & & & $\sqrt{ }$ & $\sqrt{ }$ & & & 3 & 3 \\
\hline W. scandinavica & $\sqrt{ }$ & & $\sqrt{ }$ & $\sqrt{ }$ & $\sqrt{ }$ & & $\sqrt{ }$ & 5 & 4 \\
\hline W. koreana & $\sqrt{ }$ & & & & & & & 1 & 1 \\
\hline W. iztaccihuatlensis & & & & $\sqrt{ }$ & $\sqrt{ }$ & & & 2 & 2 \\
\hline W. bedosae & $\sqrt{ }$ & & & & & & & 1 & 1 \\
\hline W. unispina & & & & & & & & 0 & 0 \\
\hline W. psammophila & & & & & & & $\sqrt{ }$ & 1 & 0 \\
\hline W. virae & $\sqrt{ }$ & & & & & & & 1 & 1 \\
\hline W. tali & $\sqrt{ }$ & & & & & & & 1 & 1 \\
\hline W. intermedia & $\sqrt{ }$ & & $\sqrt{ }$ & $\sqrt{ }$ & $\sqrt{ }$ & $\sqrt{ }$ & & 5 & 5 \\
\hline W. shanghaiensis & & & & & $\sqrt{ }$ & & & 1 & 1 \\
\hline W. granulata & $\sqrt{ }$ & & $\sqrt{ }$ & $\sqrt{ }$ & $\sqrt{ }$ & & & 4 & 4 \\
\hline W. fjellbergi & & & $\sqrt{ }$ & & & & & 1 & 1 \\
\hline W. arida & $\sqrt{ }$ & & $\sqrt{ }$ & $\sqrt{ }$ & $\sqrt{ }$ & & & 4 & 4 \\
\hline W. trisphaerae & & & $\sqrt{ }$ & $\sqrt{ }$ & $\sqrt{ }$ & & & 3 & 3 \\
\hline W. elisabethum & & & & & $\sqrt{ }$ & & & 1 & 1 \\
\hline W. denisi & $\sqrt{ }$ & $\sqrt{ }$ & $\sqrt{ }$ & $\sqrt{ }$ & $\sqrt{ }$ & & & 5 & 5 \\
\hline W. japonica & & & & & & & & 0 & 0 \\
\hline W. subbulbosa & & & & & & & $\sqrt{ }$ & 1 & 0 \\
\hline W. persimilis & & & & & & & & 0 & 0 \\
\hline W. acantha & & & & & & & & 0 & 0 \\
\hline W. bulbosa & & & & & & & & 0 & 0 \\
\hline W. meybholae & & & & & & & $\sqrt{ }$ & 1 & 0 \\
\hline W. arenicola & & & & & & & $\sqrt{ }$ & 1 & 0 \\
\hline W. nepalensis & & & & & $\sqrt{ }$ & & & 1 & 1 \\
\hline W. neocaledonica & & & & & & & $\sqrt{ }$ & 1 & 0 \\
\hline W. nadchatrami & & & & & & & & 0 & 0 \\
\hline W. brevispina & & & & & & & $\sqrt{ }$ & 1 & 0 \\
\hline W. annapurna & & & & & & & & 0 & 0 \\
\hline W. buddenbrocki & & & & & & & & 0 & 0 \\
\hline W. wandae & & & & & & & & 0 & 0 \\
\hline W. nosyboraha & & & & & & & $\sqrt{ }$ & 1 & 0 \\
\hline W. delamarei & & & & & & & & 0 & 0 \\
\hline W. setonychia & & & & & & & & 0 & 0 \\
\hline W. deharvengi & & & & & & & $\sqrt{ }$ & 1 & 0 \\
\hline
\end{tabular}




\section{FIGURE CAPTIONS}

782

Figure 1. Ordination of correlations between uses of different types of harsh habitats, analysed by pPCA (a multivariate analysis based on phylogenetic distances). The coordinates of harsh habitat types are given along the first principal component. Note that except for salinity, the uses of habitats of all types of harshness are positively correlated.

Figure 2. Parsimony reconstruction of the use of harsh habitats, i.e., any type of harsh habitat used except for salinity (A), tropical distribution (B), and distribution on former Gondwana continents (C). The corresponding character states are shown in black. The tree shapes are not exactly identical because biogeographic distributions could not be assigned to either of the categories for a few species.

Figure 3. Clade ranks of species, i.e., nodal distances to the root, using different numbers of harsh habitat types. Error bar=S.E. Note that species that do not use any harsh habitats are at a greater distance from the root (see text for analyses).

Figure 4. Harshness breadth of species from tropical vs. non-tropical regions (a) and of species of Gondwanan vs. Laurasian origin (b). The few species of intermediate localisation were not included. Error bar=S.E.

Figure 5. Clade ranks, i.e., distances to the root of the phylogenetic tree, in species from tropical vs. non-tropical regions (a) and from areas of Gondwanan vs. Laurasian origin (b). The few species with intermediate localisation were not included. Error bar=S.E. Note that the difference between Gondwanan vs. Laurasian origin disappears after including harshness breadth as a covariable (whereas harshness breadth is significant at $\mathrm{p}=0.011$, see text). 


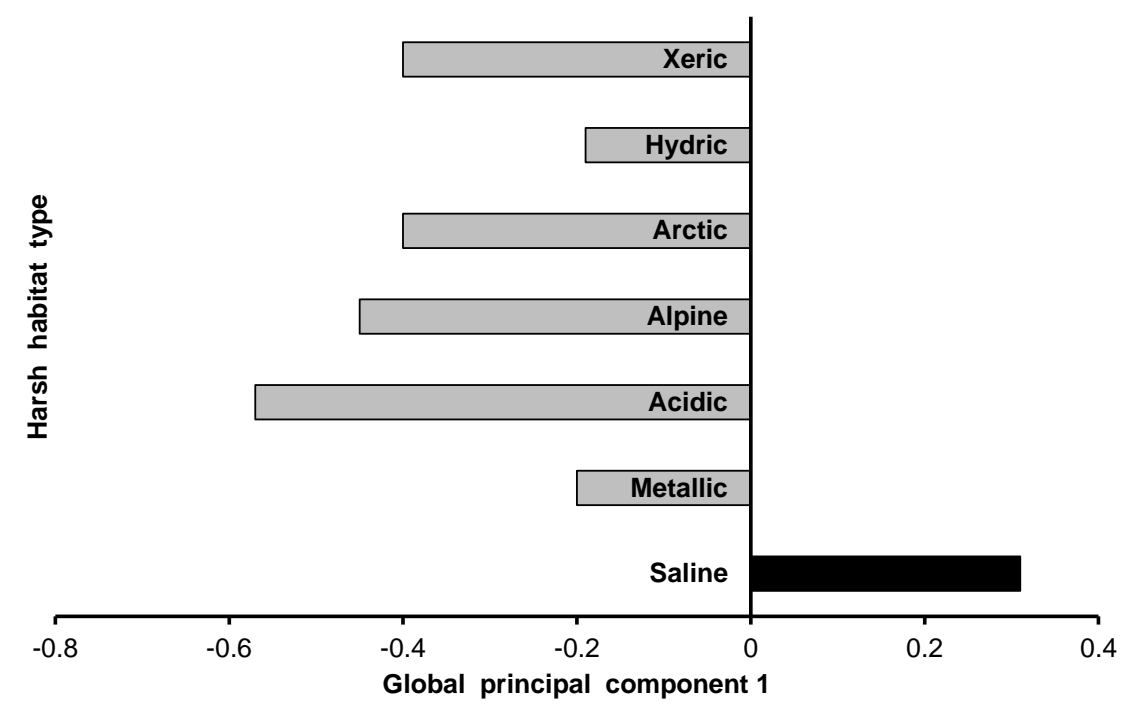

805

806 Fig. 1

807 


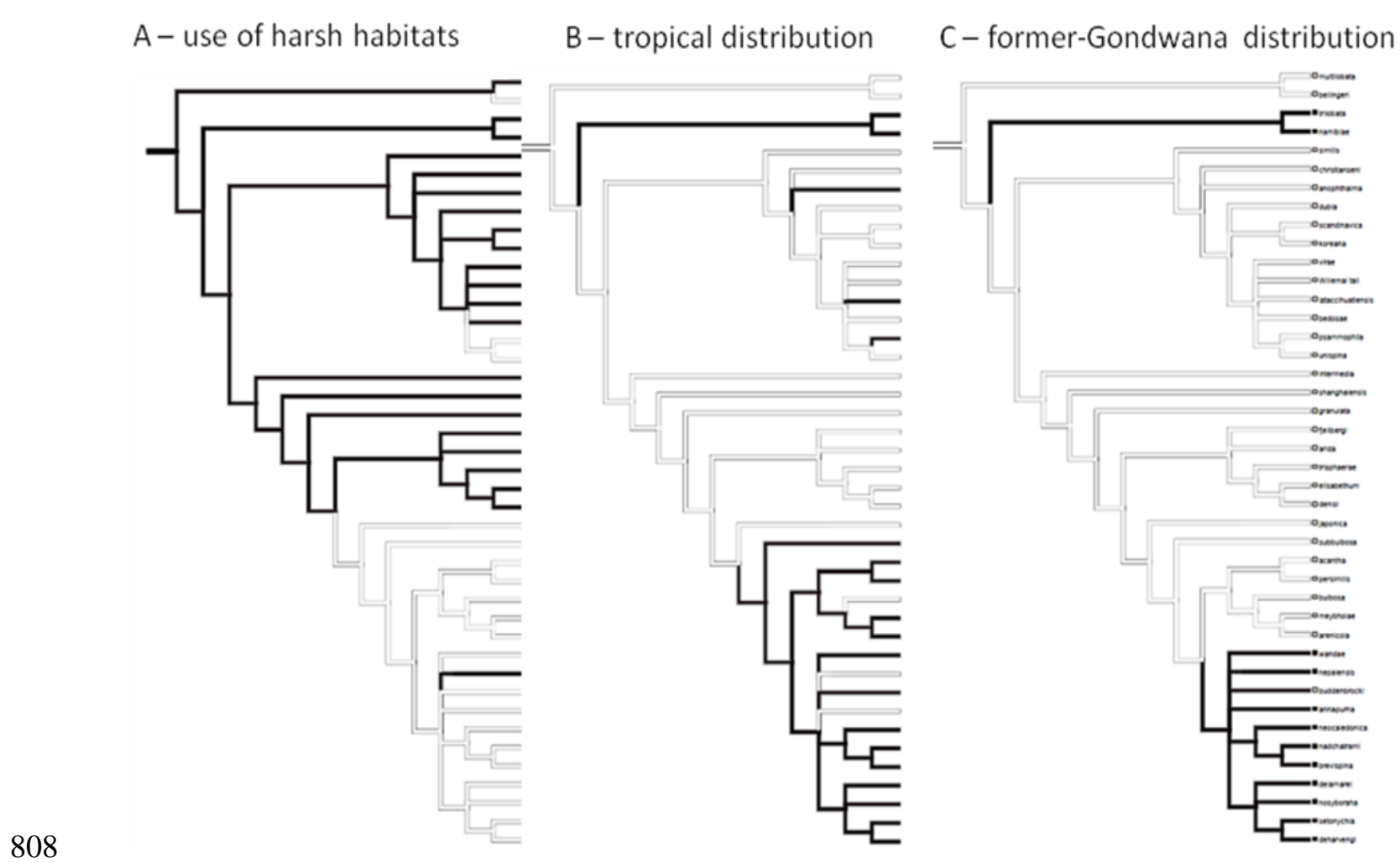

809 Fig. 2 


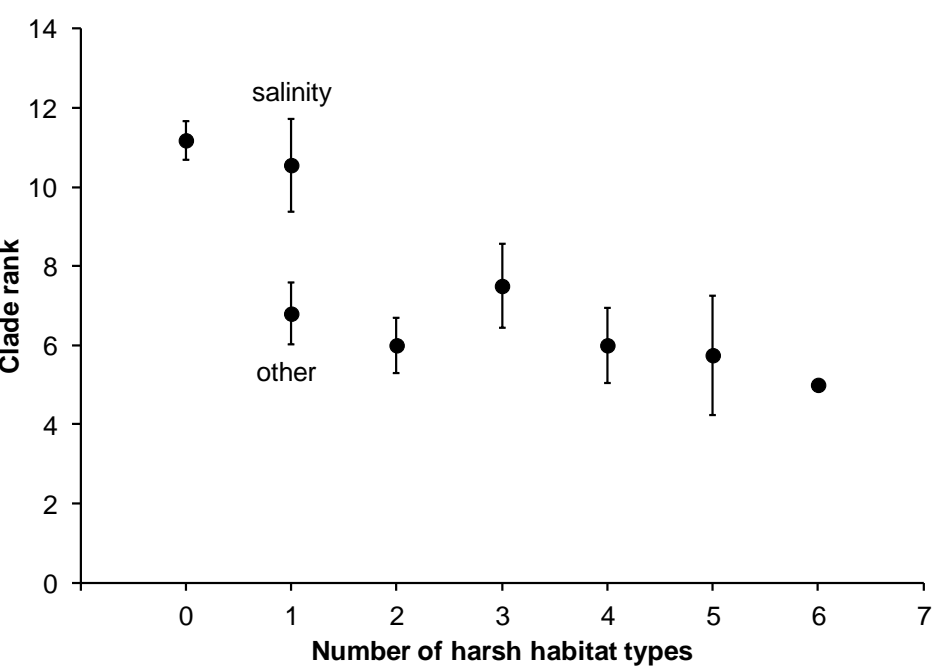

812

$813 \quad$ Fig. 3

814

815 

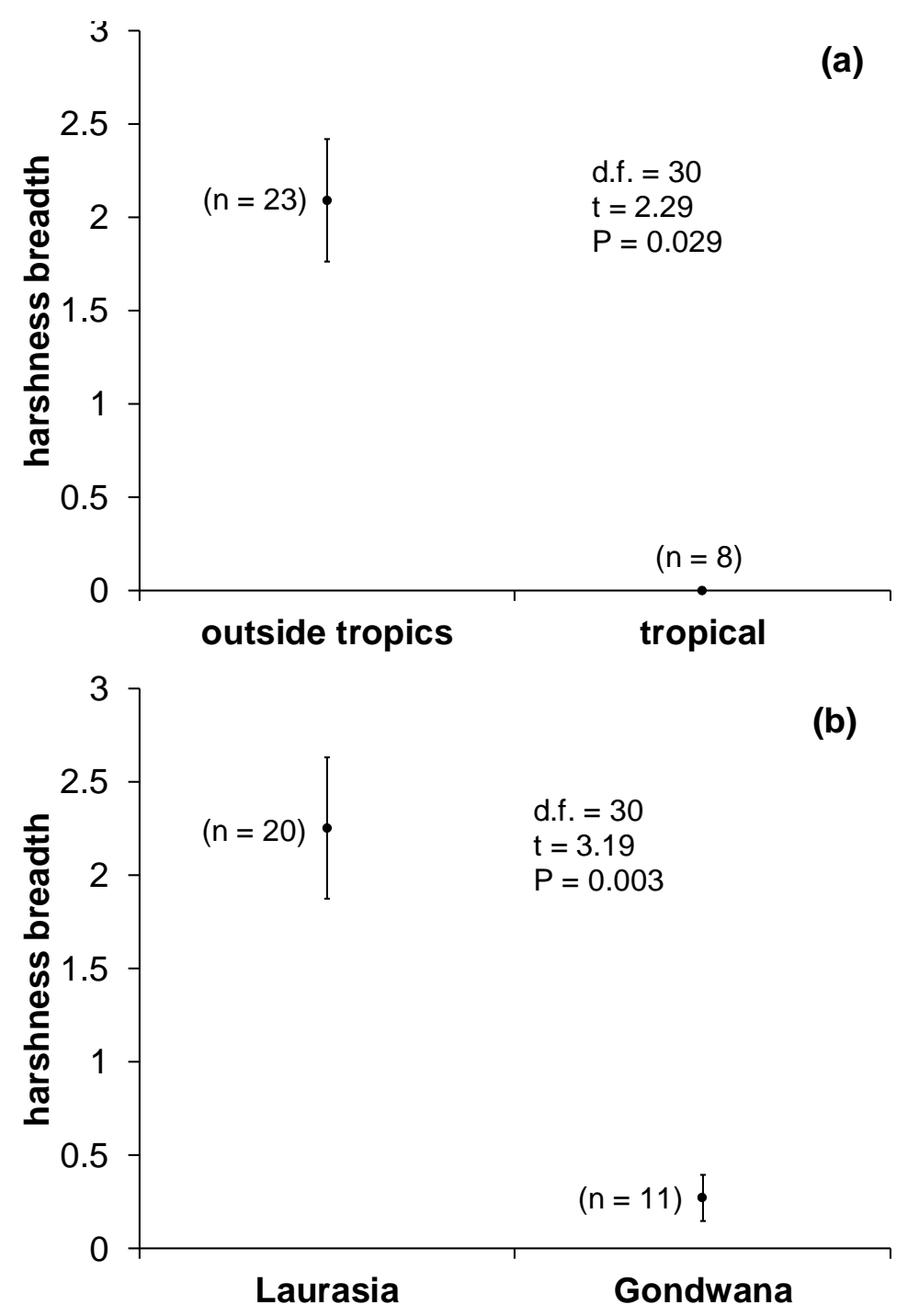

816

$817 \quad$ Fig. 4 

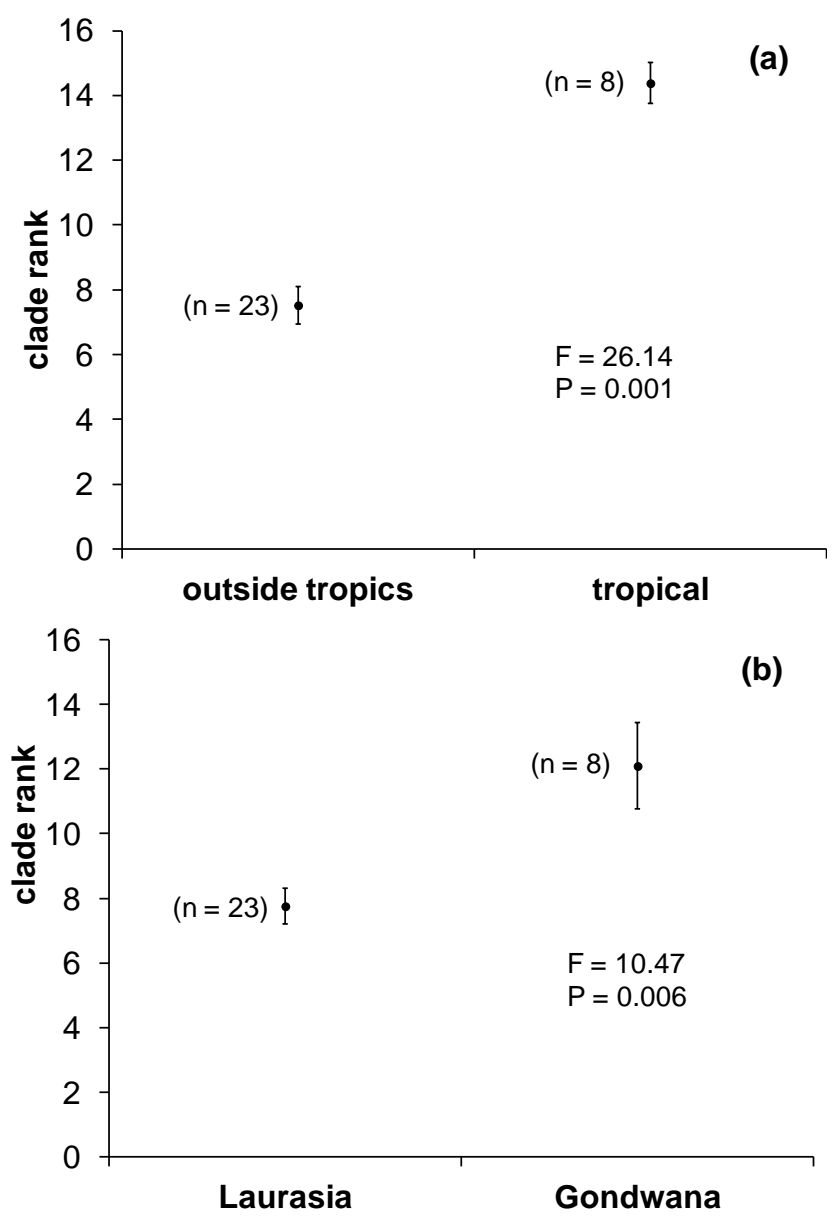

819

Fig. 5

821 


\section{Appendix S1: Phylogenetic reconstruction}

\section{$\underline{\text { Appendix S1a: General approach }}$}

Within the Class Collembola the genus Willemia belongs to the Hypogastruridae family. It differs from other hypogastrurid genera by the total lack of pigment and furcula and the small size of the slender body, which never exceeds $1 \mathrm{~mm}$ in length (Thibaud, 2004). According to their life form all Willemia species belong to the euedaphobiont sub-category Bc3b (small size, slender body, no furcula) of Rusek (2007). The study deals with 42 of the 43 species worldwide known today in this genus (list below in Appendix S1b). The remaining species $W$. biseta Christiansen \& Bellinger 1980 was excluded because it could not be studied in detail (see D'Haese 2000). Eight species have been added to the phylogenetic tree published by D’Haese (2000): W. bulbosa Bonet 1945, W. acantha Bonet 1945, W. unispina Fjellberg 2007, W. iztaccihuatlensis García Gómez \& Cutz Pool 2008, W. tali Kaprus’ \& Nevo 2003, W. psammophila Palacios-Vargas \& Thibaud 2001, W. shanghaiensis Yue 1999, and W. nosybohara Thibaud 2008.

Fifty-two morphological characters, which have been detailed in D’Haese (2000), were used for the phylogenetic analysis. Question marks (Appendix S1 b) represent either inapplicable or unknown characters. Autapomorphies, i.e. derived traits that are unique to a given terminal group, were excluded, so that only potentially informative characters were kept. All character states were polarized through comparison with three species belonging to the Hypogastruridae as outgroup: Hypogastrura vernalis Carl 1901, Orogastrura dilatata Cassagnau 1954, and Xenyllogastrura octoculata Steiner 1955.

We used morphological characters for reconstructing the phylogeny of the genus Willemia, because most species are rare and known only as collection specimens kept in conditions improper for molecular studies, a situation that often impedes worldwide 
846 invertebrate molecular phylogenies if we limit ourselves to molecular characters (Turner et al.

847 2010). Moreover, it has been shown that phylogenies based on molecular and morphological

848 characters of extant species are in general largely congruent (Jablonski \& Finarelli, 2009)

849 despite obvious discrepancies in particular cases. Finally, none of the 52 characters which

850 were used for the phylogeny of the genus Willemia (D'Haese, 2000) is related to use of harsh

851 environments. These characters concern chaetotactic setup of body and legs, which is of high

852 taxonomic value in most springtail families (including Hypogastruridae) but has little to do

853 with ecological adaptation (Gisin, 1967; Nayrolles, 1998; Rusek, 2002). The only exception is

854 pigmentation, absent from all Willemia species but present in the three outgroup species used

855 (H. vernalis, O. dilatata, X. octoculata). Thus there is no reason to believe that the use of

856 harsh environments, or a set characters correlated with it, was included in the reconstruction

857 of the phylogeny.

The data matrix (Appendix S1b) was analysed with POY version 4.1.2 (Varón et al.,

859 2010) through standard parsimony (static homology) with non-additive character coding

860 (unordered characters). The data matrix was submitted to a thousand replicates, ratchet

861 perturbation i.e. selection of $15 \%$ of characters upweighted by a factor of 3 at each iteration

862 (Nixon, 1999), tree fusing (Goloboff, 1999) and to a final branch swapping refinement

863 keeping up to $20 \%$ longer trees. Consistency (Kluge \& Farris, 1969) and Retention Indices

864 (Farris, 1989) were calculated. Bremer (Bremer, 1988) and jackknife (Farris et al., 1996)

865 branch support indices were computed.

For further calculations on phylogenetic relationships among Willemia species we

867 used a strict majority consensus tree based on six fully-resolved trees. The distance of each

868 species to the root was calculated by the number of nodes directly descending from the root to 869 it. 
870 All data matrices, character list and analysis scripts can be found below in Appendix S1b and S1c.

\section{REFERENCES}

873

874

875

876

877

878

879

880

881

882

883

884

885

886

887

Bremer, K. (1988) The limits of amino-acid sequence data in angiosperm phylogenetic reconstruction. Evolution, 42, 795-803.

D'Haese, C. (2000) Is psammophily an evolutionary dead end? A phylogenetic test in the genus Willemia (Collembola: Hypogastruridae). Cladistics, 16, 255-273.

Farris, J.S. (1989) The retention index and the rescaled consistency index. Cladistics, 5, 417419.

Farris, J.S., Albert, V.A., Källersjö, M., Lipscomb, D. \& Kluge, A.G. (1996) Parsimony jackknifing outperforms neighbor-joining. Cladistics, 12, 99-124.

Gisin, H. (1967) La systématique idéale. Zeitschrift für Zoologische Systematik und Evolutionsforschung, 5, 111-128.

Goloboff, P. (1999) Analyzing large data sets in reasonable times: solutions for composite optima. Cladistics, 15, 415-428.

Jablonski, D. \& Finarelli, J.A. (2009) Congruence of morphologically-defined genera with molecular phylogenies. Proceedings of the National Academy of Sciences of the United States of America, 106, 8262-8266.

Kluge, A.G. \& Farris, J.S. (1969) Quantitative phyletics and the evolution of anurans. Systematic Zoology, 30, 1-32.

Nayrolles, P. (1998) Analysis of a species/instars/characters table: a theoretical survey on the use of chaetotaxy in ontophylogenetic studies. Contributions to Zoology, 67, 197-220. 
892 Nixon, K.C. (1999) The parsimony ratchet, a new method for rapid parsimony analysis. Cladistics, 15, 407-414.

Rusek, J. (2002) Taxonomy of Collembola at the beginning of the millenium. Pedobiologia, 46, 215-224.

Rusek, J. (2007) A new classification of Collembola and Protura life forms. Contributions to soil zoology in Central Europe II (ed. by K. Tajovský, J. Schlaghamerský and V. Pižl), pp. 109-115. Institute of Soil Zoology, Biology Centre, Academy of Sciences of the Czech Republic, České Budějovice.

Thibaud, J.M. (2004) Synopses on Palaearctic Collembola, Volume 4, Hypogastruridae. Staatliches Museum für Naturkunde, Görlitz.

Turner, H., Lieshout, N., Van Ginkel, W.E. \& Menken, S.B.J. (2010) Molecular phylogeny of the small ermine moth genus Yponomeuta (Lepidoptera, Yponomeutidae) in the Palaearctic. PLoS ONE, 53, e9933.

Varón, A., Vinh, L.S. \& Wheeler, W.C. (2010) POY version 4: phylogenetic analysis using dynamic homologies. Cladistics, 26, 72-85. 
908 Appendix S1b: Data matrix of 52 characters in 3 outgroups and 42 species of the genus

909

$\underline{\text { Willemia. }}$

910

911

\begin{tabular}{|c|c|c|c|c|c|c|c|c|c|c|c|c|c|c|c|c|c|c|c|c|c|c|c|c|c|c|c|c|c|c|c|c|c|c|c|c|c|c|c|c|c|c|c|c|c|c|c|c|c|c|c|c|}
\hline & & & & & & & & & & & & & & & & $\begin{array}{l}1 \\
5\end{array}$ & & & & & & & & & & & & & & & & & & & & & & & & & & & & & & & & & & & & \\
\hline H. vernalis & 0 & 0 & 0 & 0 & 0 & 0 & 0 & & 0 & $?$ & 0 & 0 & 0 & 0 & 0 & 0 & 0 & 0 & 0 & 0 & 0 & 0 & 0 & 0 & 0 & 0 & 0 & 0 & 0 & $0 \quad 0$ & 0 & $\begin{array}{ll}0 & 0\end{array}$ & 0 & $0 \quad 0$ & 0 & 0 & 0 & 0 & 0 & 0 & 0 & 1 & 0 & $?$ & $?$ & $?$ & 0 & 0 & 0 & 0 & 0 & 0 \\
\hline O. dilatata & 0 & 0 & 0 & 0 & 0 & 0 & 0 & 0 & 0 & 0 & 0 & 0 & 0 & 0 & 0 & 0 & 0 & 0 & 0 & 0 & 0 & 0 & 0 & 0 & 0 & 0 & 0 & 0 & 0 & 00 & $0 \quad 0$ & 00 & 0 & 00 & 0 & 1 & 0 & 1 & 0 & 0 & 0 & 1 & 0 & 1 & 0 & 0 & 0 & ? & r. & 0 & 0 & 0 \\
\hline X. octoculata & 0 & 0 & 0 & 0 & 0 & 0 & 0 & 1 & 0 & 0 & 0 & ? & 0 & 1 & 0 & 0 & 0 & 0 & 0 & 0 & 0 & 1 & 0 & 1 & 1 & 0 & 0 & 0 & 0 & 00 & $\begin{array}{ll}0 & 0\end{array}$ & $\begin{array}{ll}0 & 0\end{array}$ & 0 & $0 \quad 0$ & 0 & 0 & 0 & 1 & 0 & 0 & 1 & 0 & $?$ & 1 & 0 & 0 & 0 & ? & 0 & 0 & 0 & 0 \\
\hline acantha & 0 & 3 & 0 & 0 & 2 & 2 & 0 & 1 & 1 & 1 & ? & 1 & 2 & 0 & 1 & 1 & 0 & 1 & 2 & 1 & 0 & 1 & 0 & ? & ? & 1 & 0 & 1 & 0 & 01 & 11 & 11 & 1 & $0 \quad 1$ & & 1 & 1 & 1 & 1 & 0 & 1 & 1 & 0 & 1 & 0 & 0 & 1 & 1 & 1 & 0 & 1 & 1 \\
\hline annapurna & 1 & 0 & 0 & 3 & 0 & 0 & 3 & 1 & 1 & 1 & 1 & 1 & 3 & 1 & 1 & 1 & 0 & 1 & 3 & 1 & 0 & 0 & 1 & 3 & 3 & 1 & 0 & 1 & 0 & 00 & $\begin{array}{ll}0 & 1\end{array}$ & 11 & 1 & $0 \quad 1$ & 1 & 1 & 1 & 1 & 1 & 1 & 1 & 1 & 0 & 1 & 1 & 1 & 1 & 1 & 1 & 1 & 0 & 1 \\
\hline anophthalma & 1 & 0 & 0 & 0 & 0 & 0 & 0 & 1 & 1 & 0 & 0 & 0 & 1 & 0 & 1 & 1 & 0 & 1 & 0 & 1 & 0 & 0 & 0 & 1 & 1 & 1 & 0 & 1 & 0 & 00 & $\begin{array}{ll}0 & 1\end{array}$ & 10 & 0 & $0 \quad 0$ & 0 & 1 & 0 & 1 & 0 & 0 & 0 & 1 & 0 & 0 & 0 & 0 & 1 & 0 & 0 & 0 & 0 & 1 \\
\hline arenicola & 0 & 2 & 2 & 2 & 2 & 2 & 2 & 1 & 1 & 1 & 1 & 0 & 2 & 1 & 1 & 1 & 0 & 1 & 2 & 1 & 0 & 1 & 0 & 2 & 3 & 1 & 0 & 0 & 0 & $0 \quad 1$ & 11 & 11 & 1 & 11 & 1 & 1 & 1 & 1 & 1 & 0 & 1 & 1 & 0 & 1 & 0 & 0 & 1 & 1 & 1 & 0 & 0 & 1 \\
\hline arida & 1 & 3 & 3 & 2 & 2 & 2 & 2 & 1 & 1 & 0 & ? & 1 & 0 & 0 & 1 & 1 & 0 & 1 & 0 & 1 & 0 & 0 & 0 & ? & ? & 1 & 0 & 1 & 0 & 00 & & 11 & 1 & $0 \quad 0$ & 0 & 0 & 0 & 1 & 1 & 0 & 1 & 1 & 0 & 1 & 0 & 1 & 1 & 0 & 0 & 0 & 1 & 1 \\
\hline bedosae & 1 & 0 & 0 & 0 & 0 & 0 & 0 & 1 & 1 & 0 & 0 & 0 & 1 & 0 & 1 & 1 & 0 & 1 & 0 & 1 & 0 & 0 & 0 & 1 & 1 & 1 & 0 & 1 & 0 & 00 & $\begin{array}{ll}0 & 1\end{array}$ & 11 & 1 & $0 \quad 1$ & 1 & 1 & 0 & 1 & 0 & 0 & 1 & 1 & 0 & 0 & 0 & 0 & 1 & 0 & 0 & 0 & 0 & 1 \\
\hline bellingeri & 0 & 0 & 0 & 0 & 0 & 2 & 0 & 1 & 1 & 0 & 0 & 1 & 0 & 0 & 1 & 1 & 0 & 1 & 0 & 1 & 0 & 0 & 0 & 1 & 1 & 1 & 0 & 0 & 0 & 00 & $\begin{array}{ll}0 & 0\end{array}$ & $\begin{array}{ll}0 & 0\end{array}$ & 0 & $0 \quad 0$ & 0 & 0 & 0 & 0 & 0 & 0 & 0 & 1 & 0 & 1 & 0 & 0 & 1 & 0 & 0 & 0 & 0 & 1 \\
\hline brevispina & 1 & 3 & 0 & 3 & 2 & 0 & 3 & 1 & 1 & 1 & 1 & 1 & 3 & 1 & 1 & 1 & 1 & 1 & 0 & 1 & 0 & 0 & 1 & 2 & 2 & 1 & 0 & 1 & 0 & 00 & $0 \quad 1$ & 11 & 1 & $0 \quad 1$ & & 1 & 1 & 1 & 1 & 1 & 1 & 1 & 1 & 1 & 1 & 1 & 1 & 1 & 1 & 1 & 0 & 1 \\
\hline buddenbrock & 1 & 0 & 0 & 3 & 0 & 0 & 3 & 1 & 1 & 1 & 1 & 1 & 3 & 1 & 1 & 1 & 1 & 1 & 2 & 1 & 0 & 0 & 1 & 3 & 3 & 1 & 0 & 1 & 0 & 00 & $\begin{array}{ll}0 & 1\end{array}$ & 11 & 1 & $0 \quad 1$ & 1 & 1 & 1 & 1 & 1 & 1 & 1 & 1 & 0 & 1 & 1 & 1 & 1 & 1 & 1 & 1 & 0 & 1 \\
\hline bulbosa & 0 & 3 & 2 & 2 & 2 & 2 & 2 & 1 & 1 & 1 & ? & 1 & 2 & 0 & 1 & 1 & 0 & 1 & 0 & 1 & 0 & 1 & 0 & ? & ? & 1 & 0 & 1 & 0 & 01 & 11 & 11 & 1 & $0 \quad 1$ & 1 & 1 & 1 & 1 & 1 & 0 & 1 & 1 & 0 & 1 & 0 & 0 & 1 & 1 & 1 & 0 & 0 & 1 \\
\hline christiansen & 1 & 3 & 0 & 0 & 0 & 0 & 0 & 1 & 1 & 0 & 0 & 0 & 1 & 0 & 1 & 1 & 0 & 1 & 0 & 1 & 0 & 0 & 0 & 1 & 1 & 1 & 0 & 1 & 0 & 00 & $0 \quad 1$ & 11 & 1 & $0 \quad 0$ & 0 & 1 & 0 & 1 & 0 & 0 & 0 & 1 & 0 & 0 & 0 & 0 & 1 & 0 & 0 & 0 & 0 & 1 \\
\hline deharvengi & 2 & 0 & 0 & 3 & 0 & 0 & 3 & 1 & 1 & 1 & 1 & 1 & 3 & 1 & 1 & 1 & 0 & 1 & 3 & 1 & 0 & 0 & 1 & 2 & 3 & 1 & 1 & 1 & 1 & 10 & $0 \quad 1$ & 11 & 1 & $0 \quad 1$ & 1 & 1 & 1 & 1 & 1 & 1 & 1 & 1 & 0 & 1 & 1 & 1 & 1 & 1 & 1 & 1 & 1 & 1 \\
\hline delamarei & 1 & 0 & 0 & 3 & 0 & 0 & 3 & 1 & 1 & ? & ? & $?$ & ? & 1 & 1 & 1 & 0 & 1 & 2 & 1 & 0 & 0 & 1 & ? & ? & 1 & 1 & 1 & 1 & 10 & $0 \quad 1$ & 11 & 1 & $0 \quad 1$ & 1 & 1 & 1 & 1 & 1 & 1 & 1 & 1 & $?$ & $?$ & ? & ? & 1 & $?$ & ? & ? & 0 & 1 \\
\hline denisi & 1 & 1 & 1 & 1 & 1 & 1 & 1 & 1 & 1 & 0 & 0 & 1 & 0 & 0 & 1 & 1 & 1 & 1 & 0 & 1 & 0 & 1 & 0 & 1 & 1 & 1 & 0 & 1 & 0 & 01 & 11 & 11 & 1 & $0 \quad 1$ & 1 & 1 & 1 & 1 & 1 & 0 & 1 & 1 & 0 & 1 & 0 & 1 & 1 & 0 & 0 & 0 & 1 & 1 \\
\hline dubia & 1 & 0 & 0 & 0 & 0 & 0 & 0 & 1 & 1 & 0 & 0 & 0 & 1 & 0 & 1 & 1 & 0 & 1 & 0 & 1 & 0 & 0 & 0 & 1 & 1 & 1 & 0 & 1 & 0 & 00 & $0 \quad 1$ & 11 & 1 & $0 \quad 1$ & 1 & 1 & 0 & 1 & 0 & 0 & 0 & 1 & 0 & 0 & 0 & 0 & 1 & 0 & 0 & 0 & 0 & 1 \\
\hline elisabethum & 1 & 1 & 1 & 1 & 2 & 1 & 1 & 1 & 1 & 0 & 0 & 1 & 0 & 0 & 1 & 1 & 1 & 1 & 0 & 1 & 0 & 1 & 0 & 1 & 1 & 1 & 0 & 1 & 0 & 01 & 11 & 11 & 10 & $0 \quad 1$ & 1 & 1 & 1 & 1 & 1 & 0 & 1 & 1 & 0 & 1 & 0 & 1 & 1 & 0 & 0 & 0 & 1 & 1 \\
\hline fjellbergi & 1 & 3 & 3 & 2 & 2 & 2 & 2 & 1 & 1 & 0 & 0 & 1 & 0 & 0 & 1 & 1 & 0 & 1 & 0 & 1 & 0 & 0 & 0 & 1 & 1 & 1 & 0 & 1 & 0 & 00 & $0 \quad 1$ & 11 & 10 & 0 & & 0 & 0 & 1 & 1 & 0 & 1 & 1 & $?$ & 1 & ? & 1 & 1 & 0 & 0 & 0 & 1 & 1 \\
\hline granulata & 1 & 0 & 0 & 0 & 2 & 2 & 0 & 1 & 1 & 0 & 0 & 1 & 0 & 0 & 1 & 1 & 0 & 1 & 0 & 1 & 0 & 0 & 0 & 1 & 1 & 1 & 0 & 1 & 0 & 00 & $0 \quad 1$ & 11 & 1 & 00 & 0 & 0 & 0 & 1 & 1 & 0 & 1 & 1 & 0 & 1 & 0 & 0 & 1 & 0 & 0 & 0 & 1 & 1 \\
\hline intermedia & 1 & 3 & 0 & 0 & 0 & 0 & 0 & 1 & 1 & 0 & 0 & 1 & 0 & 0 & 1 & 1 & 0 & 1 & 0 & 1 & 0 & 0 & 0 & 1 & 1 & 1 & 0 & 1 & 0 & 00 & $0 \quad 1$ & 11 & 1 & 00 & 0 & 0 & 0 & 1 & 1 & 0 & 1 & 1 & 0 & 1 & 0 & 0 & 1 & 0 & 0 & 0 & 0 & 1 \\
\hline iztaccihuatlensis & 1 & 1 & 0 & 0 & 0 & 0 & 0 & 1 & 1 & 0 & 0 & 0 & 1 & 0 & 1 & 1 & 0 & 1 & 0 & 1 & 0 & 0 & 0 & $?$ & ? & 1 & 0 & 1 & 0 & 0 & 11 & 11 & & 0 & 1 & 1 & 0 & 1 & ? & 0 & 1 & 1 & 0 & 0 & $?$ & 0 & 1 & 0 & 0 & 0 & 0 & 1 \\
\hline japonica & 1 & 0 & 0 & 2 & 2 & 2 & 2 & 1 & 1 & 0 & 0 & 1 & 0 & 0 & 1 & 1 & 0 & 1 & 0 & 1 & 0 & 0 & 0 & 1 & 1 & 1 & 0 & 1 & 0 & 0 & $0 \quad 1$ & 11 & 1 & 00 & & 1 & 0 & 1 & 1 & 0 & 1 & 1 & 0 & 1 & 0 & 0 & 1 & 0 & 0 & 0 & 1 & 1 \\
\hline koreana & 1 & 0 & 0 & 0 & 2 & 2 & 0 & 1 & 1 & 0 & 0 & 0 & 1 & 0 & 1 & 1 & 0 & 1 & 0 & 1 & 0 & 0 & 0 & 1 & 1 & 1 & 0 & 1 & 0 & 0 & $0 \quad 1$ & 11 & 10 & 0 & 1 & 1 & 0 & 1 & 0 & 0 & 0 & 1 & 0 & 0 & 0 & 0 & 1 & 0 & 0 & 0 & 0 & 1 \\
\hline meybholae & 0 & 2 & 2 & 2 & 2 & 2 & 2 & 1 & 1 & 1 & 1 & 1 & 2 & 1 & 1 & 1 & 0 & 1 & 3 & 1 & 0 & 1 & 0 & 2 & 3 & 1 & 0 & 0 & 0 & 0 & 11 & 11 & 11 & 1 & 1 & 1 & 1 & 1 & 1 & 0 & 1 & 1 & 0 & 1 & 0 & 0 & 1 & 1 & 1 & 0 & 1 & 1 \\
\hline multilobata & 0 & 0 & 0 & 0 & 0 & 2 & 0 & 1 & 1 & 0 & 0 & 1 & 0 & 0 & $?$ & ? & 0 & 1 & 0 & 1 & 0 & 0 & 0 & 1 & 1 & 1 & 0 & 0 & 0 & 0 & $\begin{array}{ll}0 & 0\end{array}$ & 00 & & 0 & 0 & 0 & 0 & 0 & 0 & 0 & 0 & 1 & 0 & 1 & 0 & 0 & 1 & 0 & 0 & 0 & 0 & 1 \\
\hline nadchatrami & 1 & 0 & 0 & 3 & 0 & 0 & 3 & 1 & 1 & 1 & 1 & 1 & 3 & 1 & 1 & 1 & 1 & 1 & 0 & 1 & 0 & 0 & 1 & 2 & 2 & 1 & 0 & 0 & 0 & 0 & $0 \quad 1$ & 11 & 1 & 0 & 1 & 1 & 1 & 1 & 1 & ? & 0 & 1 & 1 & 1 & 1 & 1 & 1 & ? & ? & 1 & 0 & 1 \\
\hline namibiae & 0 & 0 & 0 & 0 & 0 & 0 & 0 & 1 & 1 & 0 & 0 & 1 & 1 & 0 & 1 & 1 & 0 & 1 & 0 & ? & 1 & $?$ & 0 & 2 & 3 & 1 & 0 & 0 & 0 & 0 & $0 \quad 1$ & 10 & 00 & 0 & 1 & 1 & 0 & 1 & 0 & 0 & 0 & 0 & $?$ & 1 & 0 & 0 & 1 & 0 & 0 & ? & 0 & 1 \\
\hline neocaledonica & 1 & 0 & 0 & 3 & 0 & 0 & 3 & 1 & 1 & 1 & 1 & 1 & 3 & 1 & 1 & 1 & 1 & 1 & 2 & 1 & 0 & 0 & 1 & 2 & 2 & 1 & 0 & 1 & 0 & 0 & $0 \quad 1$ & 11 & & 0 & 1 & 1 & 1 & 1 & 1 & 1 & 1 & 1 & 1 & 1 & 1 & 1 & 1 & 1 & 1 & 1 & 0 & 1 \\
\hline nepalensis & 1 & 0 & 0 & 3 & 0 & 0 & 3 & 1 & 1 & 1 & 1 & 1 & 3 & 1 & 1 & 1 & 0 & 1 & 2 & 1 & 0 & 0 & 1 & 2 & 2 & 1 & 1 & 1 & 0 & 0 & $0 \quad 1$ & 11 & 10 & 0 & 1 & 1 & 1 & 1 & 1 & 1 & 1 & 1 & 0 & 1 & 1 & 1 & 1 & 1 & 1 & 1 & 0 & 1 \\
\hline nosyboraha & 1 & 0 & 0 & 3 & 0 & 0 & 3 & 1 & 1 & 1 & 1 & $?$ & $?$ & 1 & 1 & 1 & 1 & 1 & 1 & 1 & 0 & 0 & 1 & 3 & 3 & 1 & 1 & 1 & 1 & 1 & $0 \quad 1$ & 11 & 10 & 0 & 1 & 1 & 1 & 1 & 1 & 1 & 1 & 1 & 0 & 0 & 1 & 0 & $?$ & ? & ? & ? & 0 & 1 \\
\hline persimilis & 0 & 3 & 0 & 0 & 2 & 2 & 0 & 1 & 1 & 1 & ? & 1 & 2 & 0 & 1 & 1 & 0 & 1 & 2 & 1 & 0 & 1 & 0 & $?$ & ? & 1 & 0 & 1 & 0 & 0 & 11 & 11 & 10 & 0 & 1 & 1 & 1 & 1 & 1 & 0 & 1 & 1 & 0 & 1 & 0 & 0 & 1 & 1 & 1 & 0 & 0 & 1 \\
\hline psammophila & 0 & 0 & 0 & 0 & 0 & 0 & 0 & 1 & 1 & 1 & 0 & 0 & 1 & 0 & 1 & 1 & 0 & 1 & 1 & 1 & 0 & 0 & 0 & 3 & 3 & 1 & 1 & 1 & 1 & 1 & $0 \quad 1$ & 10 & 00 & 0 & 0 & 1 & 0 & 1 & ? & 0 & 1 & 1 & 0 & 0 & 0 & 0 & 1 & ? & 0 & 0 & 0 & 1 \\
\hline scandinavica & 1 & 0 & 0 & 0 & 2 & 2 & 0 & 1 & 1 & 0 & 0 & 0 & 1 & 0 & 1 & 1 & 0 & 1 & 0 & 1 & 0 & 0 & 0 & 1 & 1 & 1 & 0 & ? & 0 & 0 & 0 & 11 & 10 & 0 & 1 & 1 & 0 & 1 & 0 & 0 & 0 & 1 & 0 & 0 & 0 & 0 & 1 & 0 & 0 & 0 & 0 & 1 \\
\hline setonychia & 2 & 0 & 0 & 3 & 0 & 0 & 3 & 1 & 1 & ? & $?$ & $?$ & ? & 1 & 1 & 1 & 0 & 1 & 3 & 1 & 0 & $?$ & ? & $?$ & ? & 1 & 1 & 1 & 1 & 1 & 0 & 11 & & 0 & & 1 & 1 & 1 & 1 & 1 & 1 & 1 & $?$ & ? & $?$ & $?$ & 1 & ? & $?$ & ? & 1 & 1 \\
\hline shanghaiensis & 1 & 0 & 0 & 0 & 2 & 2 & 0 & 1 & 1 & ? & ? & $?$ & ? & ? & ? & ? & ? & 1 & 0 & 1 & 0 & 0 & 0 & $?$ & ? & 1 & 0 & 0 & 0 & 0 & 0 & 11 & & 00 & 0 & 0 & 0 & ? & ? & 0 & 1 & 1 & $?$ & ? & $?$ & $?$ & 1 & ? & ? & 0 & 0 & 1 \\
\hline similis & 1 & 0 & 0 & 0 & 0 & 0 & 0 & 1 & 1 & 0 & 0 & 1 & 1 & 0 & 1 & 1 & 0 & 1 & 0 & 1 & 0 & 0 & 0 & 1 & 1 & 1 & 0 & 1 & 0 & 0 & 0 & $0 \quad 1$ & & 0 & 0 & 1 & 0 & 1 & 0 & 0 & 0 & 1 & 0 & 0 & 0 & 0 & 1 & 0 & 0 & 0 & 0 & 1 \\
\hline subbulbosa & 1 & 2 & 2 & 2 & 2 & 2 & 2 & 1 & 1 & 1 & 1 & 1 & 2 & 0 & 1 & 1 & 0 & 1 & 0 & 1 & 0 & 0 & 0 & 2 & 3 & 1 & 0 & 1 & 0 & 0 & 0 & 11 & 1 & 0 & 0 & 1 & 0 & 1 & 1 & 0 & 1 & 1 & 0 & 1 & 0 & 0 & 1 & 1 & 1 & 0 & 0 & 1 \\
\hline tali & 1 & 1 & 1 & 1 & ? & 0 & 1 & 1 & 1 & 0 & 0 & 0 & 1 & 0 & 1 & 1 & 0 & 1 & 0 & 1 & 0 & 0 & 0 & 1 & 1 & 1 & 1 & 1 & 0 & 0 & 0 & 11 & 10 & 0 & 1 & 1 & 1 & 1 & 0 & 0 & 1 & 1 & 0 & 0 & 0 & 0 & 1 & 1 & 0 & 0 & 0 & 1 \\
\hline trilobata & 0 & 0 & 0 & 0 & 0 & 0 & 0 & 1 & 1 & 0 & 0 & 1 & 1 & 0 & 1 & 1 & 0 & 1 & 0 & ? & 1 & 0 & 0 & 2 & 3 & 1 & 0 & 0 & 0 & 0 & 0 & 10 & 0 & 0 & 1 & 1 & 0 & 1 & 0 & 0 & 0 & 0 & $?$ & 1 & 0 & 0 & 1 & ? & ? & ? & 0 & 1 \\
\hline trisphaerae & 1 & 3 & 1 & 1 & 2 & 2 & 1 & 1 & 1 & 0 & 0 & 1 & 0 & 0 & 1 & 1 & ? & 1 & 0 & 1 & 0 & 0 & 0 & 1 & 1 & 1 & 0 & 1 & 0 & 0 & 0 & 11 & & 0 & 0 & 0 & 0 & 1 & 1 & 0 & 1 & 1 & 0 & 1 & 0 & 1 & 1 & 0 & 0 & 0 & 1 & 1 \\
\hline unispina & 1 & 0 & 0 & 0 & 0 & 0 & 0 & 0 & 1 & $?$ & ? & 1 & 0 & 0 & 1 & 1 & ? & 1 & 0 & 1 & 0 & 0 & 0 & 1 & 1 & 1 & 1 & 1 & 1 & 1 & 0 & 11 & & 0 & 1 & 1 & 0 & 1 & 0 & 0 & 1 & 1 & 0 & 0 & 0 & 0 & 1 & ? & ? & 0 & 1 & 1 \\
\hline virae & 1 & 0 & 0 & 0 & 0 & 0 & 0 & 1 & 1 & 0 & 0 & 0 & 1 & 0 & 1 & 1 & 0 & 1 & 0 & 1 & 0 & 0 & 0 & 1 & 1 & 1 & 0 & 1 & 0 & 0 & 0 & 11 & & 0 & 1 & 1 & 1 & 1 & 0 & 0 & 1 & 1 & ? & 0 & 0 & 0 & 1 & 0 & 0 & 0 & 0 & 1 \\
\hline wandae & 1 & 0 & 0 & 3 & 0 & 0 & 3 & 1 & 1 & 1 & 1 & 1 & 3 & 1 & 1 & 1 & 1 & 1 & 2 & 1 & 0 & 0 & 1 & 3 & 3 & 1 & & & 0 & 0 & 0 & . & & 0 & & 1 & & 1 & 1 & 1 & 1 & 1 & 1 & 1 & 1 & 1 & 1 & 1 & 1 & 1 & 0 & 1 \\
\hline
\end{tabular}


915 Appendix S1c: Files used for the construction of the strict consensus phylogenetic tree.

916

917 Printout of files used by Cyrille d'Haese for the construction of the strict consensus phylogenetic tree

918 (Fig. 1). The file will-bre1.trees needed to calculate bremer support is not provided because of its size

919 ( $58 \mathrm{Mo})$. All these files are available upon request at dhaese@mnhn.fr

920

921

922

The following file willemia2000.ss is the original data matrix from D'Haese (2000) in Hennig86 format:

923

924

925

926

927

928

929

930

931

932

933

934

935

936

937

938

939

940

941

942

943

944

945

946

947

948

949

950

951

952

953

954

955

956

957

958

959

960

961

962

963

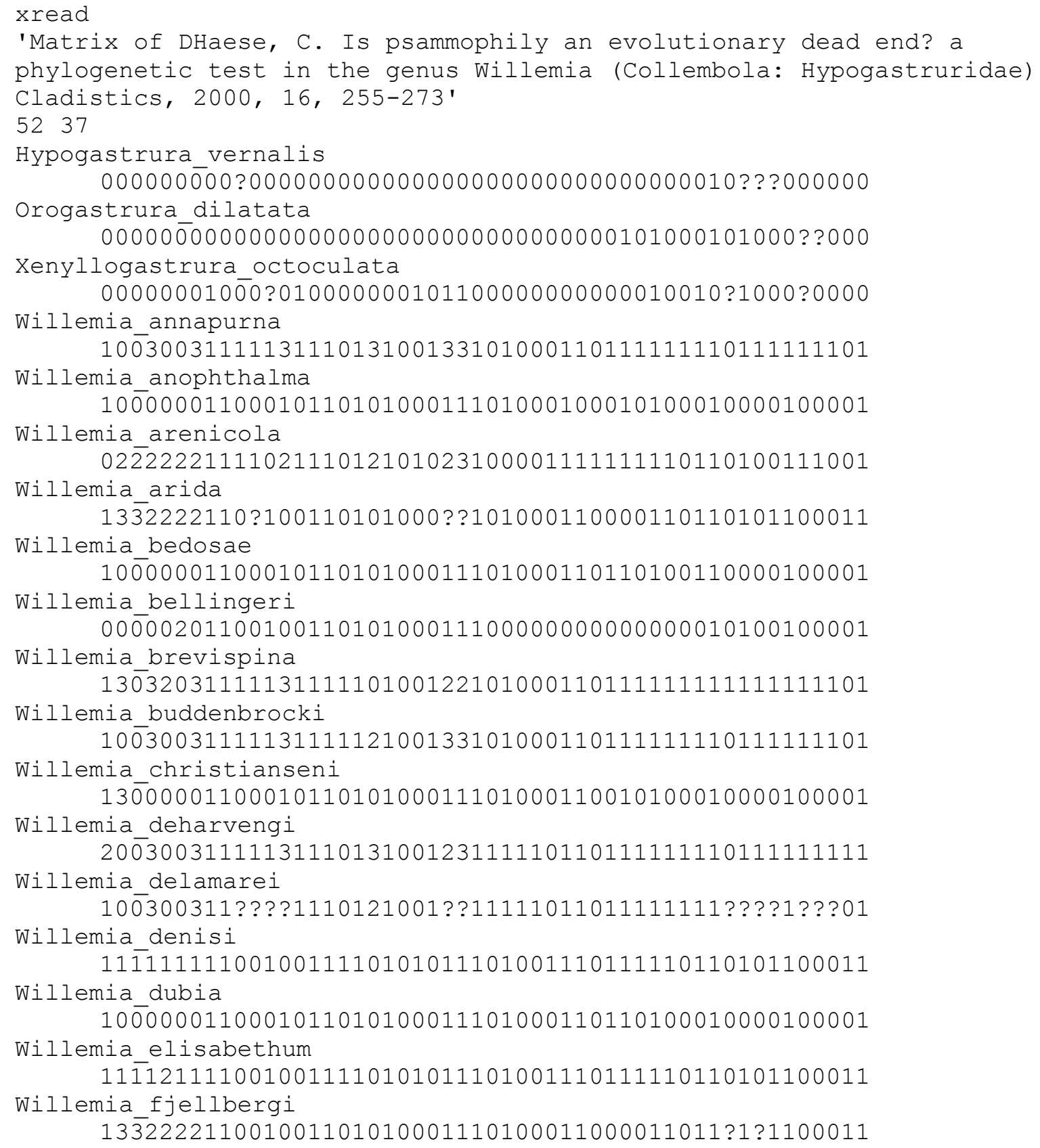


1006

1007

1008

1009

1010

1011

1012

1013

1014

1015

1016

1017

1018

1019

1020

1021

Willemia granulata $10 \overline{00220110010011010100011101000110000110110100100011}$ Willemia intermedia $13 \overline{00000110010011010100011101000110000110110100100001 ~}$ Willemia japonica 1002222110010011010100011101000110010110110100100011 Willemia koreana $10 \overline{00220110001011010100011101000110110100010000100001 ~}$ Willemia meybholae $02 \overline{2} 2222111112111013101023100001111111110110100111011$ Willemia multilobata $00 \overline{000} 0201100100$ ??010100011100000000000000010100100001 Willemia nadchatrami

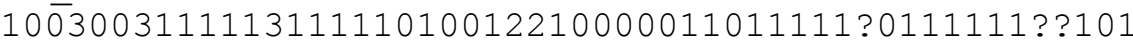
Willemia namibiae

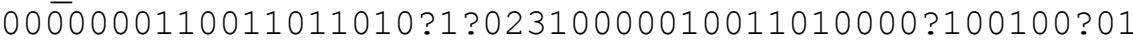
Willemia neocaledonica

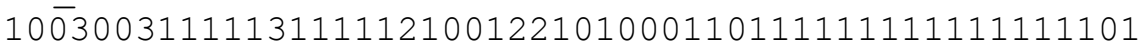
Willemia nepalensis $10 \overline{03003111113111012100122111000110111111110111111101 ~}$ Willemia persimilis 0300220111 ?120110121010??101001110111110110100111001 Willemia scandinavica $10 \overline{0} 022011000101101010001110 ? 000110110100010000100001$ Willemia setonychia 200300311????11101310????11111011011111111????1???11 Willemia similis $10 \overline{00000110011011010100011101000010010100010000100001 ~}$ Willemia subbulbosa $12 \overline{2} 2222111112011010100023101000110010110110100111001$ Willemia trilobata $00 \overline{00000110011011010 ? 1002310000010011010000 ? 1001 ? ? ? 01 ~}$ Willemia trisphaerae

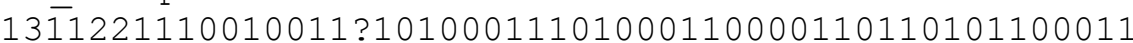
Willemia virae $10 \overline{0} 000011000101101010001110100011011110011 ? 000100001$ Willemia wandae $10 \overline{0} 3003111113111112100133111000110111111111111111101$

; ccode - 0.51 proc /; ; $\mathrm{cn}$

$\{0$ On antennal_segment_IV, apical vesicle large small absent;

$\{1$ Señsilla el on anteñnal segment IV subcylindrical (Figs. 2A and 2D) candle flame-shaped (Fig. $\overline{2}$ B) globülar (Fig. 2C)

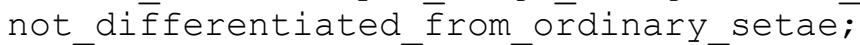

$\{2$ Sensilla_e2 on āntenñal_segment_IV subcylindrical_(Figs._2A_and_2D) candle_flame-shapéd_(Fig._̌̄ B) globülar_(Fig._2C) not diéfferentiated from or rinary setae; $\{3$ Sensilla e3 on āntenñal segment IV subcylindrical (Fig. 2A) candle_flame-shaped_(Fig._2B) globülar_(Fig._2C) globulār_in_cavity__(Fig. $\overline{2}$ D) ; \{4 Sensilla-d on antennā segment IV subcylindrical (Figs. 2A and 2D)

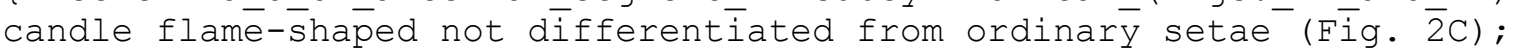
\{5 Sens̄illa_il on antenñal_segment_IV subcȳindrical_-(Figs._2A_añ_2D) candle flame-shapè (Fig. $\overline{2}$ B)

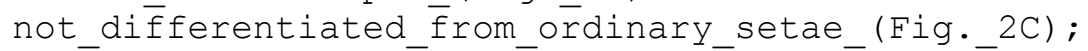


$1022\{6$ Sensilla_i2_on_antennal_segment_IV subcylindrical_(Fig._2A)

1023

1024

1025

1026

1027

1028

1029

1030

1031

1032

1033

1034

1035

1036

1037

1038

1039

1040

1041

1042

1043

1044

1045

1046

1047

1048

1049

1050

1051

1052

1053

1054

1055

1056

1057

1058

1059

1060

1061

1062

1063

1064

1065

1066

1067

1068

1069

1070

1071

1072

1073

1074

1075

1076

1077

1078

candle_flame-shaped_(Fig._2B) globular_(Fig._2C)

globulār_in_cavity_ $\left(\right.$ Fig. $\left.{ }_{-}{ }^{2} \mathrm{D}\right)$;

$\{7$

Small internal sensilla of sensory organ of antennal segment III (Figs.

2A_to__D) free covered_in_part_by_a_tegümeñtal_fold;

\{8 Thir 8 _and_fourth_antēnnàl_segments $\bar{s}$ clearly_separated

ventrally $\bar{y}_{\text {_slightly_fused; }}$

$\{9$ Antennàl segment II with 12 setae 11 setae;

$\{10$ Antenna $\bar{I}$ segment_I_with 7 setae 6 setae;

$\left\{11\right.$ Prelabrā_chaetotaxy_with ${ }^{-} 4$ setae 2 setae;

$\{12$ Labral_chäetotaxy_with 5.5.4_setae $\overline{4} .5 .4$ setae 2.5 .4 setae

5.3.4 setaē;

$\{13$ Séta a0 on the head present (Fig. 1A) absent (Fig. 1B);

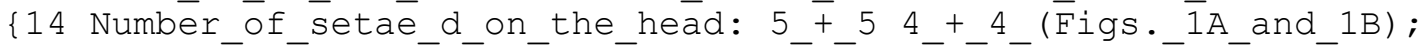

$\left\{15\right.$ Number_of_setae_v_on the head: ${ }^{-}{ }^{-}{ }^{-}{ }^{-} 1_{-}^{-}{ }^{-}{ }_{-}^{-}-\left(\right.$Figs. ${ }_{-}^{-} \mathrm{A}_{-}^{-}$and $\left.{ }^{-} 1 \mathrm{~B}\right)$;

\{16 Setae_ci_on_the_head present absent;

$\{17$ Corneüles preseñt absent;

$\{18$ Postantennal_organ_with 4_to_9_vesicles_(Fig._1A) 10_to_15_vesicles more_than_15_vesícles_(Fig._1 $\bar{B})$;

$\{19$ Setae_al_of_thoracic_tergum_III_positioned on thoracic_tergum_III

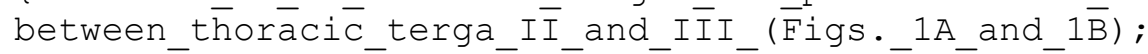

$\{20$ On_second_and_third_thoracic_terga,_setāe_a $\overline{1}$ present absent;

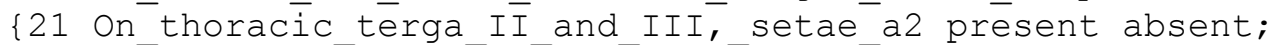

$\{22$ On_thoracic_terga_II_and_III,_setae_m3 present_(Fig._1A)

absent $($ Fig. $1 \mathrm{~B})$;

$\{23$ Tibiotarsis___and_II_with 19 _setae 17 setae 12 setae 11 setae;

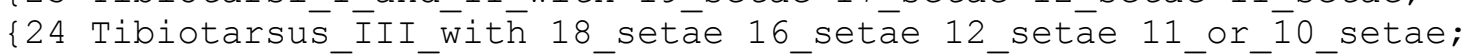

$\{25$ Tibiotarsi with_tenent_hair without_tenent_hair;

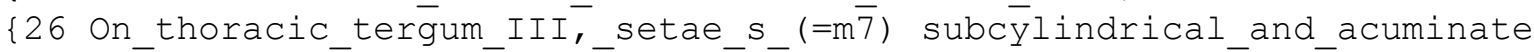
lanceolate;

$\{27$ On_abdominal_terga_II_and_III,_setae_s

subcylīndrical_añd_acumināte_(Fig._1A) lānceolate_(Fig._1B);

$\{28$ On_abdomināl_tēergum_IV,_setae_s subcylindricā̄_and_ācuminate lanceolate;

$\{29$ On_abdominal_tergum_V,_setae_s subcylindrical_and_acuminate lanceolate;

$\{30$ On_abdominal_terga_II_and_III,_setae_a2 present absent;

\{31 On_abdominal_terga_II_and_III,_setae_m2 present_(Fig._1A) absent_(Fig._1B);

\{32 On abdominal terga II and III, setae m3 present absent;

$\{33$ On_abdominal_terga_I_II_añ_II $\bar{I}$,_tegümentary_granulation normal

coarse_secondary_granulation_near_setae_s;

\{34 On_abdominal_tergum_IV, setae_m1 présent_(Fig._1A)

absent_(Fig._1B)

$\{35$ On_abdominal_tergum_IV, setae_m2 present absent;

\{36 On_abdominal_tergum_IV,_setae_m3 present_(Fig._1A)

absent_(Fig._1B)

$\{37$ On_abdominal_tergum_IV,_setae_m3' present absent;

$\{38$ On_abdominal_tergum_IV,_setae_p5 present_(Fig._1A) absent_(Fig._1B)

\{39 On_abdominal_tergum_V,_setae_a3 present_(Fig._1A) absent_(Fig._1B);

$\left\{40\right.$ On_abdominal_tergum_V, ${ }^{-}$_setae_s

in_p3_position_i.e._p2_present_( $\overline{\text { Fig._1A) }}$

in_p2_position_i.e._p2_absent_(Fig._1B);

$\{4 \overline{1}$ Ventral_tub̄e with more thān_4_+_4_setae with_4_1_4_setae;

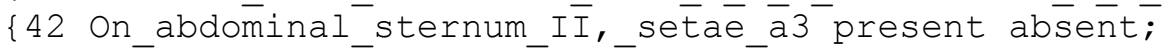


$1079\{43$ On_abdominal_sternum_IV,_setae_al present_(Fig._3A)

1080 absent_(Fig._3B);

1081 \{44 On_abdominal_sternum_IV, 4_rows_of_setae_(Fig._3A)

1082 3_rows_of_setae_(Fig._3B $\overline{)}$;

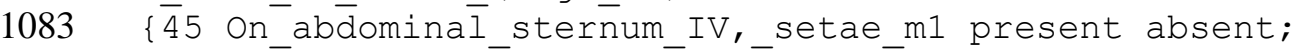

$1084\{46$ Fur̃ca present absent;

$1085\{47$ On_anal_lobes, _setae_e present_(Fig._4A) absent_(Fig._4B);

1086 \{48 On_anal_lobes, setae_z present_(Fig. $\left.{ }^{-} 4 \mathrm{~A}\right)$ absent_(Fig._4B);

1087 \{49 On_anal_lobes,_distal_setae_of_hr_group present_(Fig._4A)

1088 absent_(Fig._4B);

$1089\{50$ Anāl_spiñes present absent;

$1090\{51$ Pigmentation present absent;

1091 ;

1092

1093 
1094 The following file willemia2011_char.ss is the new matrix with 5 Willemia species added along with 1095 the character list:

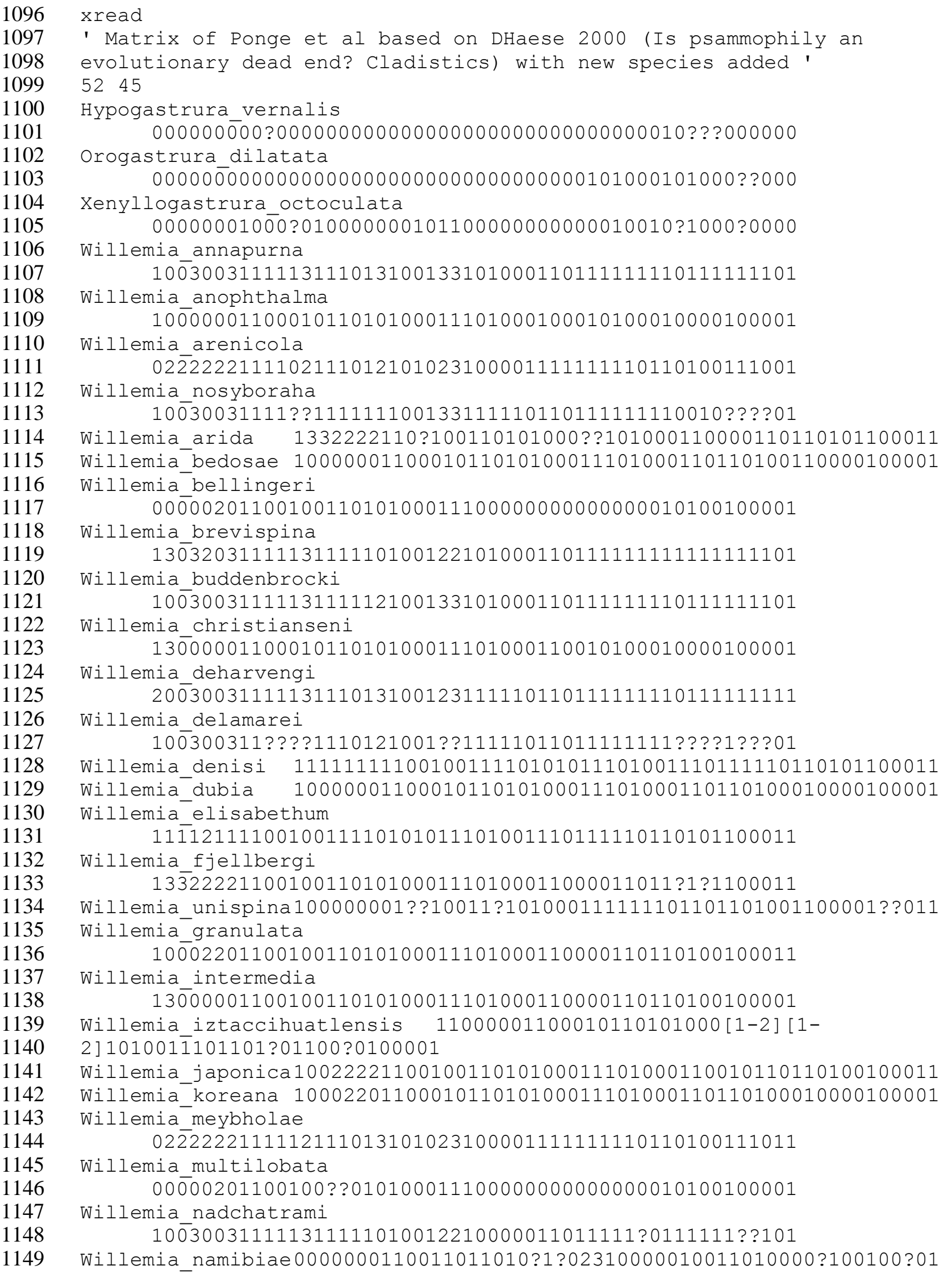


1181

1182

1183

1184

1185

1186

1187

1188

1189

1190

1191

1192

1193

1194

1195

1196

1197

1198

1199

1200

1201

1202

1203

1204

1205

1206

1207

Willemia neocaledonica

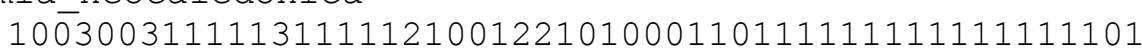

Willemia nepalensis

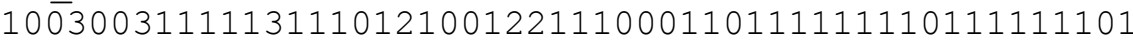
Willemia persimilis 0300220111?120110121010??101001110111110110100111001 Willemia_psammophila

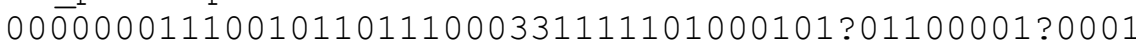

Willemia bulbosa 0322222111?1201101[0-

1] 1010 ??101001110111110110100111001

Willemia_acantha 0300220111?120110121010??101001110111110110100111011 Willemia scandinavica

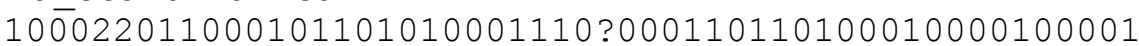

Willemia setonychia 200300311????11101310????11111011011111111????1???11

Willemia shanghaiensis 100022011????????101000??100000110000??011????1??001 Willemia similis 1000000110011011010100011101000010010100010000100001 Willemia subbulbosa $12 \overline{2} 2222111112011010100023101000110010110110100111001$ Willemai tali 1111?01110001011010100011111000110111100110000110001 Willemia trilobata

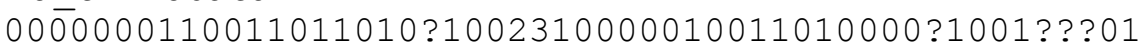
Willemia trisphaerae 1311221110010011?10100011101000110000110110101100011 Willemia virae $\quad 100000011000101101010001110100011011110011 ? 000100001$ Willemia_wandae 1003003111113111112100133111000110111111111111111101 ;

ccode - $0.51 ;$

proc/;

;

$\mathrm{Cn}$

$\{0$ On antennal segment IV, apical vesicle large small absent;

$\{1$ Sensilla_el_on antennal_segment_IV subcylindrical_(Figs._2A and_2D) candle_flame-shapéd_(Fig._2B) globular_(Fig._2C)

not_differentiated_from ordinary setae;

$\{2$ Sensilla_e2_on_antenñal_segment_IV subcylindrical_(Figs._2A_and_2D) candle flame-shapè (Fig. 2 B) globular (Fig. 2C) not differentiated from ordinary setae;

$\{3$ Sensilla_e3_on_āntenñal_segment_IV subcylindrical_(Fig._2A) candle_flamē-shapèd_(Fig. 2 B) globular_(Fig._2C) globulār in cavity (Fig. $\overline{2}$ D); $\{4$ Sensilila d on antennal segment IV subcylindrical (Figs. 2A and 2D) candle flame-shaped not differentīated from ordinary setae- (Fig. $\overline{2} \mathrm{C}$ ); $\{5$ Sensilla_il_on_antenñal_segment_IV subcy $\bar{l}$ indrical_-(Figs._2A_and_2D) candle flame-shapèd_(Fig. $\overline{2}$ B) not_differentiated_from_ordinary_setae_(Fig._2C); $\{6$ Sensilla i2 on antenñal segment IV subcylindrical (Fig. 2A) candle flame-shapēd (Fig. $\overline{2}$ B) globular (Fig. 2C) globulār in cavity $($ Fig. $\overline{2}$ D) ; $\{7$ Small_internal_sensilla_of_sensory_organ_of antennal_segment_III_(Figs. 2A to 2D) frēe covered in part by a tegümental fold; \{8 Third_and_fourth antēnnàl_segments clearly_sēparated ventrally slightly fused; $\{9$ Antennal_segment_II_with 12 _setae 11 setae; 
$1208\{10$ Antennal_segment_I_with 7_setae 6_setae;

$1209\{11$ Prelabrā chaetotaxy with 4 setae 2 setae;

$1210\{12$ Labral_chäetotaxy_with 5.5. 4 _setae $\overline{4} .5 .4$ setae 2.5.4_setae

12115.3 .4 setaē;

$1212\{13$ séta_a0_on_the_head present_(Fig._1A) absent_(Fig._1B);

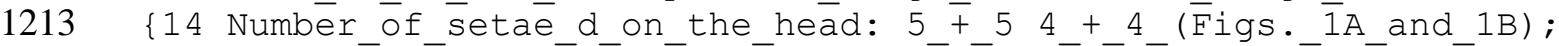

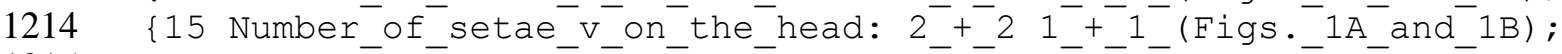

$1215\{16$ Setae $\bar{c} 1$ on the héad present absēnt;

$1216\{17$ Corneüles preseñt absent;

$1217\{18$ Postantennal_organ_with 4_to_9_vesicles_(Fig._1A) 10_to_15_vesicles

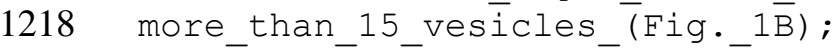

$1219\{19$ Setae_al_of_thoracic_tergum_III_positioned on_thoracic_tergum_III

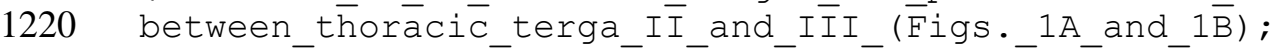

$1221\{20$ On_second_and_third_thoraciciterga,_setāe_a $\overline{1}$ present absent;

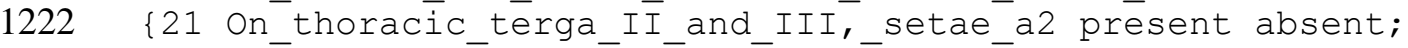

1223 \{22 On_thoracic_terga_II_and_III,_setae_m3 present_(Fig._1A)

1224 absent_(Fig._1B) ;

$1225\{23$ Tibiotarsis___and_II_with 19_setae 17_setae 12_setae 11_setae;

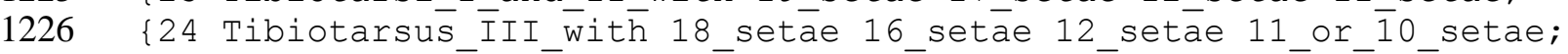

$1227\{25$ Tibiotarsi with_tenent_hair without_tenent_hair;

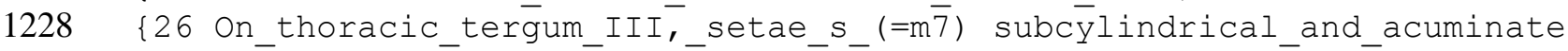
lanceolate;

$\{27$ On_abdominal_terga_II_and_III,_setae_s

subcylīndrical_ānd_acumināte_(Fig._1A) lānceolate_(Fig._1B);

$\{28$ On_abdomināl_têrgum_IV,_setae_s subcylindrical__and_ācuminate lanceolate;

\{29 On_abdominal_tergum_V,_setae_s subcylindrical_and_acuminate lanceolate;

$\{30$ On_abdominal_terga_II_and_III,_setae_a2 present absent; $\{31$ on_abdominal_terga_II_and_III,_setae_m2 present_(Fig._1A) absent ${ }^{-}$(Fig. 1B)

$\{32$ On_abdominal_terga_II_and_III, setae_m3 present absent;

$\{33$ On_abdominal_terga_I_II_and_III, tegumentary_granulation normal coarse_secondary_granūation_neār_setae_s;

\{34 On_abdominal_tergum_IV,_setae_m1 présent_(Fig._1A) absent_(Fig. $1 \mathrm{~B}) \overline{\text {; }}$

$\{35$ On_abdominal_tergum_IV,_setae_m2 present absent;

$\{36$ On_abdominal_tergum_IV,_setae_m3 present_(Fig._1A) absent_(Fig._1B)

$\{37$ On_abdominal_tergum_IV, setae_m3' present absent;

$\{38$ On_abdominal_tergum_IV,_setae_p5 present_(Fig._1A)

absent_(Fig._B ${ }_{-}^{-} \overline{\text {; }}$

$\{39$ On_abdominal_tergum_V,_setae_a3 present_(Fig._1A) absent_(Fig._1B);

$\{40$ On_abdominal_tergum_V, setae_s

in_p3_position_i.e.e.p2_present_( $\overline{\mathrm{F}}$ ig._1A)

in_p2_position_i.e._p2_absent_(Fig. ${ }_{-}$B B);

$\left\{4 \overline{1}\right.$ Ventral_tube with more thān_4_+ ${ }^{+}{ }^{4}$ setae with_4_1_4_setae;

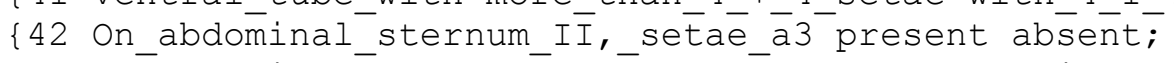

$\{43$ On_abdominal_sternum_IV,_setae_al present_(Fig._3A) absent_(Fig._3B)

$\{44$ On_abdominal_sternum_IV, 4_rows_of_setae_(Fig._3A)

3_rows_of_setae_(Fig._3B $)$;

$\{\overline{4} 5$ On_abōominal_sternum_IV,_setae_m1 present absent;

$\{46$ Furca present absent;

$\{47$ On_anal_lobes, _setae_e present_(Fig._4A) absent_(Fig._4B);

$\{48$ On_anal_lobes, _setae_z present_(Fig._4A) absent_(Fig._4B);

$\{49$ On_anal_lobes,_distal_setae_of_hr_group present_(Fig._4A)

absent_(Fig •_4 B ) ; 
$1266\{50$ Anal_spines present absent;

$1267\{51$ Pigmentation present absent;

1268

;

1269

1270 
1271 The following file willemia2011.ss is the same data matrix but without the character list to be directly 1272 readable by POY:

1273

1274

1275

1276

1277

1278

1279

1280

1281

1282

1283

1284

1285

1286

1287

1288

1289

1290

1291

1292

1293

1294

1295

1296

1297

1298

1299

1300

1301

1302

1303

1304

1305

1306

1307

1308

1309

1310

1311

1312

1313

1314

1315

1316

1317

1318

1319

1320

1321

1322

1323

1324

1325

1326

xread

' Matrix of Ponge et al based on DHaese 2000 (Is psammophily an

evolutionary dead end? Cladistics) with new species added '

5245

Hypogastrura vernalis

$000000 \overline{0} 00$ ?000000000000000000000000000000010???000000

Orogastrura dilatata $00000 \overline{0} 00000000000000000000000000000101000101000$ ??000

Xenyllogastrura octoculata

$000000010 \overline{0} 0 ? 010000000101100000000000010010 ? 1000 ? 0000$

Willemia annapurna $10 \overline{0} 3003111113111013100133101000110111111110111111101$

Willemia anophthalma $10 \overline{0} 0000110001011010100011101000100010100010000100001$

Willemia arenicola

$02 \overline{2} 2222111102111012101023100001111111110110100111001$

Willemia nosyboraha

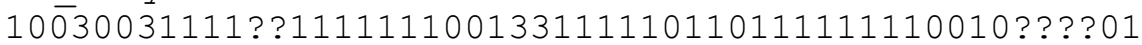

Willemia arida 1332222110?100110101000??101000110000110110101100011

Willemia_bedosae 1000000110001011010100011101000110110100110000100001

Willemia bellingeri $00 \overline{0} 0020110010011010100011100000000000000010100100001$

Willemia brevispina $13 \overline{0} 3203111113111110100122101000110111111111111111101$

Willemia buddenbrocki

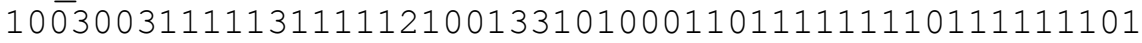

Willemia christianseni $13 \overline{0} 0000110001011010100011101000110010100010000100001$

Willemia deharvengi

$20 \overline{0} 3003111113111013100123111110110111111110111111111$

Willemia delamarei

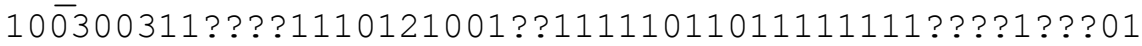

Willemia_denisi 1111111110010011110101011101001110111110110101100011

Willemia dubia 1000000110001011010100011101000110110100010000100001 Willemia elisabethum

$11 \overline{1} 1211110010011110101011101001110111110110101100011$

Willemia_fjellbergi

$13 \overline{3} 222211001001101010001110100011000011011$ ?1?1100011

Willemia_unispina100000001??10011?101000111111101101101001100001??011

Willemia_granulata $10 \overline{0} 0220110010011010100011101000110000110110100100011$

Willemia_intermedia $13 \overline{00000110010011010100011101000110000110110100100001}$

Willemia_iztaccihuatlensis 11000001100010110101000 [1-2] [1-

2] $101001 \overline{1} 101101$ ?01100?0100001

Willemia japonica 1002222110010011010100011101000110010110110100100011 Willemia_koreana 1000220110001011010100011101000110110100010000100001 Willemia meybholae $02 \overline{2} 2222111112111013101023100001111111110110100111011$

Willemia multilobata $00 \overline{000201100100 ? ? 010100011100000000000000010100100001}$

Willemia nadchatrami

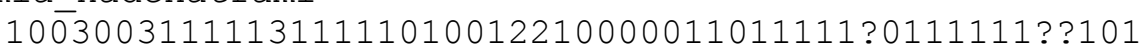

Willemia_namibiae0000000110011011010?1?02310000010011010000?100100?01 
1354

1355

1356

1357

1358

1359

1360

1361

Willemia_neocaledonica

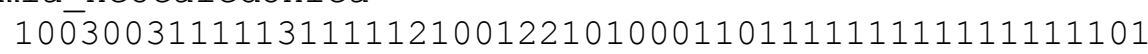

Willemia nepalensis

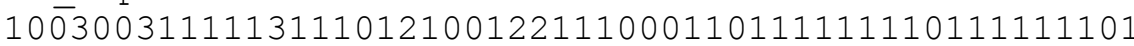

Willemia persimilis 0300220111?120110121010??101001110111110110100111001

Willemia psammophila

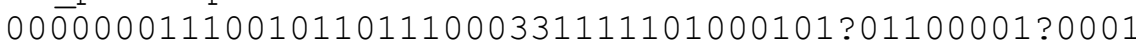

Willemia bulbosa 0322222111?1201101[0-

1] 1010 ?? $\overline{1} 01001110111110110100111001$

Willemia_acantha 0300220111?120110121010??101001110111110110100111011 Willemia scandinavica

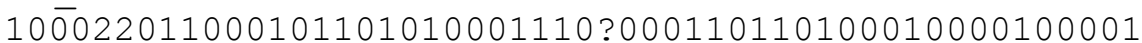

Willemia setonychia 200300311????11101310????11111011011111111????1???11

Willemia_shanghaiensis 100022011????????101000??100000110000??011????1??001

Willemia_similis 1000000110011011010100011101000010010100010000100001 Willemia subbulbosa $12 \overline{2} 2222111112011010100023101000110010110110100111001$

Willemai tali 1111?01110001011010100011111000110111100110000110001 Willemia trilobata

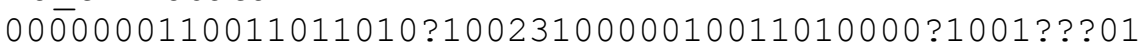
Willemia trisphaerae

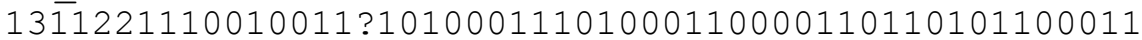

Willemia virae $\quad 100000011000101101010001110100011011110011 ? 000100001$ Willemia_wandae 1003003111113111112100133111000110111111111111111101 ;

ccode -0.51

proc/; 
1362 The following file will.sh is the main analysis script for POY:

1363 wipe ()

1364 read ("willemia2011.ss")

1365 set (root: "Hypogastrura_vernalis")

1366 build (1000)

1367 select (unique)

1368 perturb (iterations:2, ratchet:(0.15,3), swap(tbr, trees:2))

1369 select (unique)

1370 fuse ()

1371 select (unique)

1372 swap (threshold:20)

1373 swap (all, visited:"will-brel.trees", timeout:3600)

1374 select ()

1375 report ("will.tre", trees:(total))

1376 report ("will_results.ss", phastwinclad, trees: (hennig, total))

1377 report ("will-cons.tre", consensus, "will-cons", graphconsensus)

1378 report ("will-stats.txt", treestats, ci, ri)

1379 report ("will-diag.txt", diagnosis)

1380 exit () 
1384 will-cons.pdf (consensus in pdf format), will-cons.tre (consensus in text format), will-stats (tree length 1385 ci and ri), and will.tre (the six equally parsimonious trees) are the results of the analysis.

1386

1387 will-cons.pdf:

Strict Majority Consensus Tree

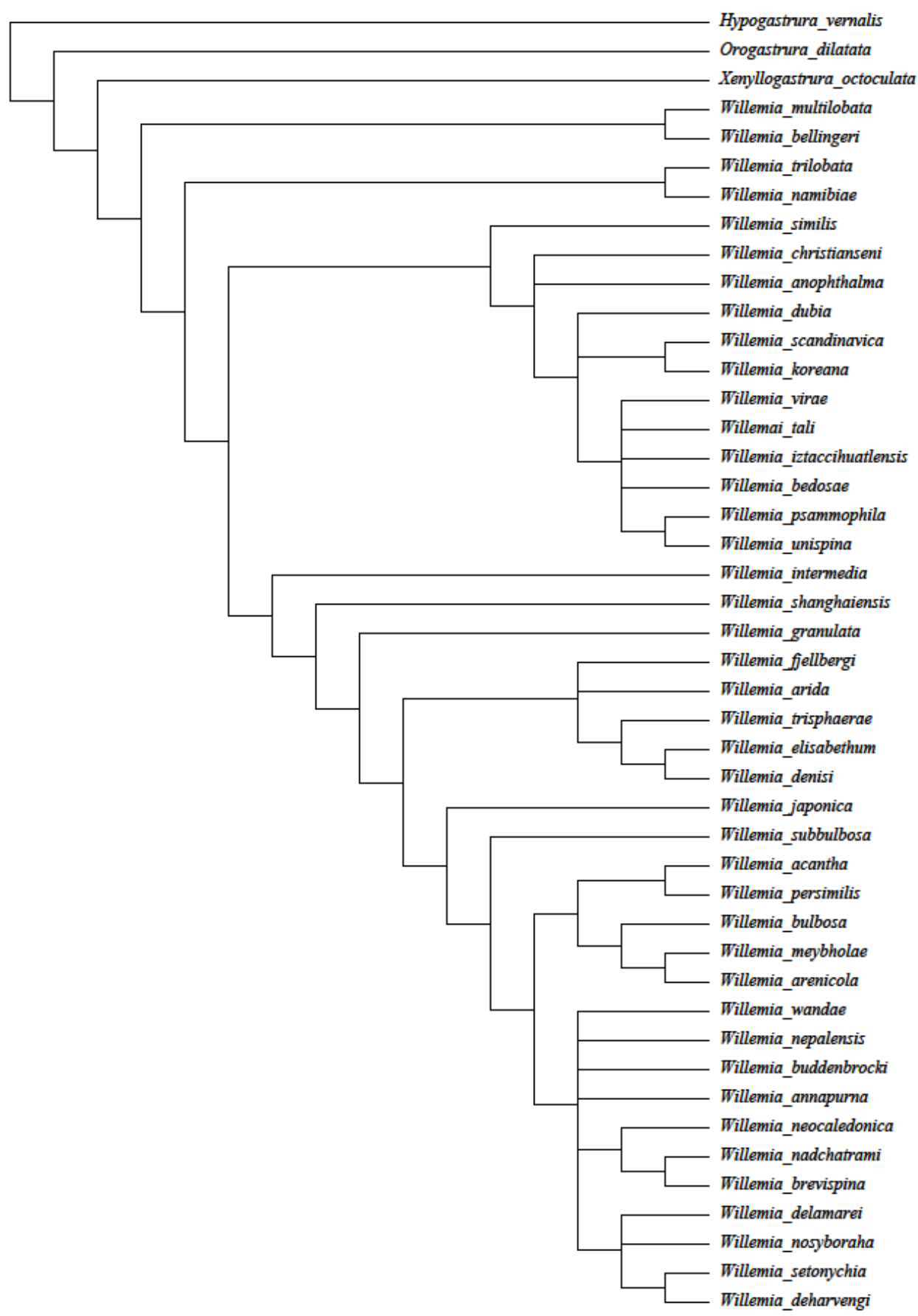


will-cons.tre:

1391 Strict Majority Consensus Tree

1392 (Hypogastrura vernalis, (Orogastrura dilatata, (Xenyllogastrura octoculat 1393 a, ((Willemia multilobata,Willemia béllingeri), ((Willemia trilōobata, Will 1394 emia_namibiae), ((Willemia_similis, (Willemia_christiansen $\bar{i}$,Willemia anop

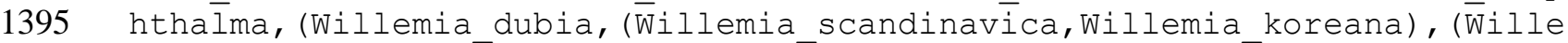
1396 mia virae,Willemaì tali,Willemia íztaccihuatlensis,Willēemia bedosae, (Wi 1397 llemia psammophila,Willemia unisp̄ina))))), (Willemia intermedia, (Willemi 1398 a shanghaiensis, (Willemia_granulata, ( Willemia_fjelïbergi,Willemia arid

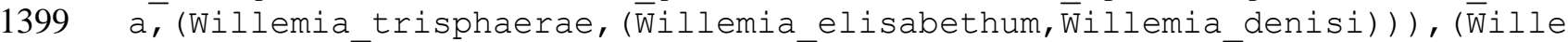
1400 mia japonica, (Willemia subbulbosa, () (Willemia acantha, Willemia persimil 1401 is), (Willemia bulbosa, (Willemia meybholae,Willemia arenicola))), (Willem 1402 ia wandae, Willemia nepalensis, Willemia buddenbrocki, Willemia annapurna, 1403 (Wìllemia_neocaledōnica, (Willemia_nadchatrami,Willemia_brevis̄pina)), (Wi 1404 llemia de $\bar{l}$ amarei,Willemia_nosyborăha, (Willemia_setonychia,Willemia_deha

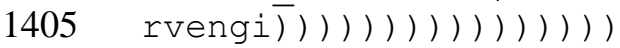


1408 will-stats:

1409

1410

1411

1412

1413

1414

1415

1416

1417

1418

1419

1420

1421

1422

1423

1424

1425

1426

1427

1428

1429

1430

Tree length Number of hits

Trees Found:

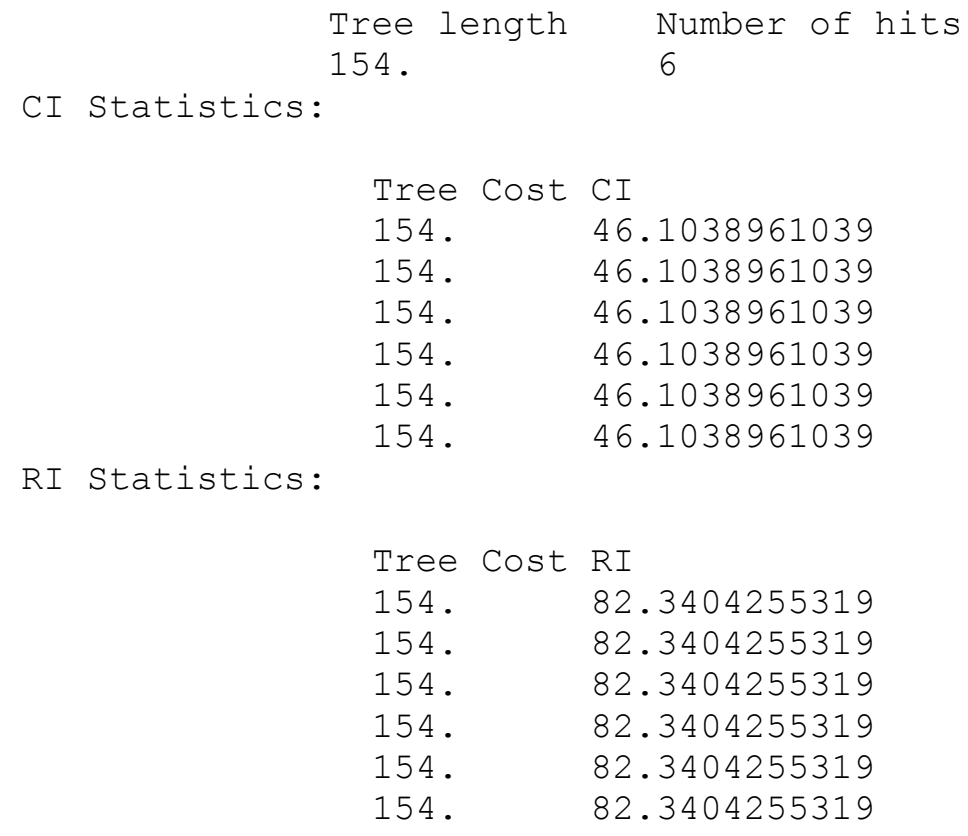

1432 
will.tre:

1434

1435

1436

1437

1438

1439

1440

1441

1442

1443

1444

1445

1446

1447

1448

1449

1450

1451

1452

1453

1454

1455

1456

1457

1458

1459

1460

1461

1462

1463

1464

1465

1466

1467

1468

1469

1470

1471

1472

1473

1474

1475

1476

1477

1478

1479

1480

1481

1482

1483

1484

1485

1486

1487

1488

1489

(Hypogastrura_vernalis, (Orogastrura_dilatata, (Xenyllogastrura_octoculat a , (Willemia multilobata,Willemia bellingeri), ( Willemia trilobata ,Willemia_nāmibiae), ( (Willemia_similis, ( Willemia_christ̄ianseni ,Willemia_anophthalma), ( (Willemia_dubia, (Willemia_scandinavica ,Willemia_koreana)), (Willemia_iztāccihuatlensis, (W̄illemia_bedosae , ( Willemīa_unispina,Willemia_psammophila), (Willemia_viraē,Willemai_tal i) ) ) ) )

)), (Willemia_intermedia, (Willemia_shanghaiensis, (Willemia_granulata , (( Willemia_fjellbergi,Willemia_arida), (Willemia_trisphaérae

,(Willemia_elisabethum,Willemia_denisi))), (Willemía_japonica

, (Willemia_subbulbosa, ( ( Willemīa_persimilis,Willemia_acantha)

, (Willemia_bulbosa, (Willemia_meyb̄olae,Willemia_areničcola)))

, (Willemiānepalensis, (Willēemia_neocaledonica, (Willemia_nadchatrami

,Willemia_brevispina))), (Willemia_annapurna, (Willemia_būdenbrocki

, (Willemiā_wandae, (Willemia_nosybōraha, (Willemia_delamarei

,(Willemia setonychia,Willemia deharvengi)))) )) ) )) )) )) )) )) )) ) [154.];

(Hypogastrüra_vernalis, (Orogastrura_dilatata, (Xenyllogastrura_octoculat a

, (Willemia_multilobata,Willemia_bellingeri), ( Willemia_trilobata

,Willemia_nāmibiae), ( (Willemia_similis, ( Willemia_christ̄ianseni

,Willemia_anophthalma), ( (Willemia_dubia, (Willemia_scandinavica

,Willemia koreana)), ( (Willemia vī̄ae, (Willemia unispina, Willemia psammo phila)

), (Willemia_bedosae, (Willemia_iztaccihuatlensis,Willemai_tali))))))

, Willemia intermedia, (Willemīa_shanghaiensis, (Willemia_ōranulata

, ((Willemīa fjellbergi,Willemiāarida), (Willemia trisph̄aerae

, (Willemia_elisabethum,Willemia_denisi))), (Willemía_japonica

, Willemia_subbulbosa, ( (Willemia_persimilis,Willemía_acantha)

, (Willemia_bulbosa, (Willemia_meybholae,Willemia_arenicola)))

, ( Willemiānnepalensis, (Willēemia_neocaledonica, (Willemia_nadchatrami

,Willemia_brevispina))), (Willemiāannapurna, (Willemia_būddenbrocki

, (Willemiā wandae, (Willemia nosybōraha, (Willemia delāmarei

,(Willemia_setonychia,Willemia_deharvengi)) )) )) ) ) )) )) )) ) )) )) ) [154.];

(Hypogastrüra_vernalis, (Orogastrura_dilatata, (Xenyllogastrura_octoculat a

, ( Willemia_multilobata,Willemia bellingeri), ( (Willemia_trilobata

,Willemia nāmibiae), ( (Willemia similis, (Willemia christīanseni

, Willemiāanophthalma, (Willemīa_dubia, ( Willemiāsscandinavica

,Willemia_k̄oreana), ( Willemia_unispina,Willemia_psammophila)

, (Willemiābedosae, (Willemia_íztaccihuatlensis, (Willemia_virae,Willemai tali)

())))))), (Willemia_intermedia, (Willemia_shanghaiensis, (Willemia_granula ta

, ( Willemia_fjellbergi, (Willemia_arida, (Willemia_trisphaerae

, (Willemia_êlisabethum,Willemia_denisi))) ), (Willemia_japonica

, (Willemia_subbulbosa, ( (Willemīa_persimilis,Willemia_acantha)

, (Willemia bulbosa, (Willemia meybholae,Willemia arenicola)))

, ( Willemiā nepalensis, ( (Wil $\bar{l}$ emia nosyboraha, Wi $\bar{l}$ lemia delamarei)

,(Willemia_setonychia,Willemia_dēharvengi))), (Willemiāannapurna

, (Willemia buddenbrocki, (Willemia wandae, (Willemia neocaledonica

,(Willemia_nadchatrami,Willemia_brevispina)))) )) ) ) )) )) ) ) ) ) ) ) [154.] ;

(Hypogastrūra_vernalis, (Orogastrura_dilatata, (Xenyllogastrura_octoculat a

, (Willemia_multilobata,Willemia_bellingeri), ( Willemia_trilobata ,Willemia_nāmibiae), ( (Willemia_similis, (Willemia_christīanseni 
, (Willemia_anophthalma, ( (Willemia_scandinavica,Willemia_koreana) , (Willemia_dubia, ( (Willemia_unispina,Willemia_psammophila), (Willemia_vi rae

,(Willemia bedosae, (Willemia_iztaccihuatlensis,Willemai_tali)))))))))

, Willemia_intermedia, (Willemia_shanghaiensis, (Willemia_granulata

, ((Willemía_fjellbergi,Willemiāarida), (Willemia_trisphaerae

,(Willemia_elisabethum,Willemia_denisi))), (Willemía_japonica

, (Willemia_subbulbosa, ( (Willemia_persimilis,Willemía_acantha)

, (Willemia bulbosa, (Willemia meybholae,Willemia arenicola)))

, ( Willemián nepalensis, ( Willemia nosyboraha, Wi $\bar{l}$ lemia delamarei)

, (Willemia_setonychia,Willemia_deh̄arvengi))), (Willemiāannapurna

, (Willemia_buddenbrocki, (Willemia_wandae, (Willemia_neoc̄aledonica

,(Willemia_nadchatrami,Willemia_brevispina)))) )) ) ) )) )) )) ) ) ) ) [154.] ;

(Hypogastrüra_vernalis, (Orogastrura_dilatata, (Xenyllogastrura_octoculat a

, (Willemia_multilobata,Willemia_bellingeri), ( Willemia_trilobata

,Willemia nāmibiae), ( (Willemia_similis, (Willemia_christīanseni

, (Willemiāanophthalma, ( (Willemia_scandinavica, Wìllemia_koreana)

, Willemia dubia, (Willemia virae, ( Willemia iztaccihuatlensis

,Willemia_bedosae), (Willemāi_tali, (Willemia_unispina,Willemia_psammophi (a))) )

)))), (Willemia_intermedia, (Willemia_shanghaiensis, (Willemia_granulata

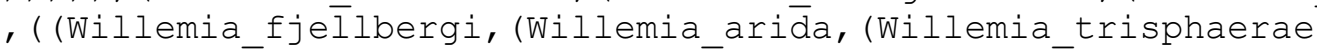

,(Willemia $\bar{e} l i s a b e t h u m, W i l l e m i a ~ \overline{d e n i s i)))),(W i l l e ̄ e m i a ~ j a p o n i c a ~}$

, Willemia_subbulbosa, ( (Willemia_persimilis,Willemia_acantha)

, (Willemia_bulbosa, (Willemia_meybholae,Willemia_areničcola)))

, ( Willemiānnepalensis, (Willēemia_neocaledonica, (Willemia_nadchatrami

,Willemia_brevispina))), (Willemiāannapurna, (Willemia_būdenbrocki

, (Willemiā_wandae, (Willemia_nosybōraha, (Willemia_delamarei

,(Willemia_setonychia,Willemia_deharvengi)))) )) ) ) )) )) )) ) )) )) ) [154.] ;

(Hypogastrura_vernalis, (Orogastrura_dilatata, (Xenyllogastrura_octoculat a

, ( Willemia_multilobata,Willemia_bellingeri), ( Willemia_trilobata

,Willemia_nāmibiae), ( (Willemia_similis, (Willemia_christīanseni

, Willemiā anophthalma, (Willemīa dubia, ( Willemiā scandinavica

,Willemia_k̄oreana), ( Willemia_iztaccihuatlensis,Wíllemia_bedosae)

, (Willemiā_virae, (Willemai_tali, (Willemia_unispina,Willē̄ia_psammophila

))) ))

))), (Willemia_intermedia, (Willemia_shanghaiensis, (Willemia_granulata

, (Willemia fj̄ellbergi, (Willemia arida, (Willemia trisphaerae

,(Willemia_ēlisabethum,Willemia_denisi)))), (Willēemia_japonica

, (Willemia_subbulbosa, ( ( Willemia_persimilis,Willemia_acantha)

, (Willemia_bulbosa, (Willemia_meybholae,Willemia_arenic̄ola)))

, (Willemiānnepalensis, ( (Willemia_nosyboraha, Willemia_delamarei)

,(Willemia_setonychia,Willemia_de⿳亠丷arvengi))), (Willemiāannapurna

, (Willemia_buddenbrocki, (Willemia_wandae, (Willemia_neoćcaledonica

,(Willemia_nadchatrami,Willemia_brevispina)))) )) )) ) )) )) )) ) ) ) [154.] ; 
1541 will_results.ss is the data matrix with the resulting optimal trees readable by Winclada (obtained by 1542 the will_results.sh script run in POY):

1543 xread 'Generated by POY 4.0' 5245

1544 Willemia wandae 1003003111113111112100133111000110111111111111111101

1545 Willemia virae $100000011000101101010001110100011011110011 ? 000100001$

1546 Willemia trisphaerae

$154713112211 \overline{1} 0010011$ ?10100011101000110000110110101100011

1548 Willemia trilobata 0000000110011011010?1002310000010011010000?1001???01

1549 Willemai_tali 1111?01110001011010100011111000110111100110000110001

1550 Willemia subbulbosa

$1551 \quad 12222221 \overline{1} 1112011010100023101000110010110110100111001$

1552 Willemia_similis 1000000110011011010100011101000010010100010000100001

1553 Willemia_shanghaiensis

$155410002201 \overline{1}$ ????????101000??100000110000??011????1??001

1555 Willemia setonychia

$155620030031 \overline{1}$ ????11101310????11111011011111111????1???11

1557 Willemia_scandinavica

$155810002201 \overline{1} 000101101010001110 ? 000110110100010000100001$

1559 Willemia_acantha 0300220111?120110121010??101001110111110110100111011

1560 Willemia bulbosa

$156103222221 \overline{1} 1$ ?1201101[01]1010??101001110111110110100111001

1562 Willemia_psammophila

$156300000001 \overline{1} 10010110111000331111101000101 ? 01100001 ? 0001$

1564 Willemia persimilis

$156503002201 \overline{1} 1$ ?120110121010??101001110111110110100111001

1566 Willemia nepalensis

$156710030031 \overline{1} 1113111012100122111000110111111110111111101$

1568 Willemia neocaledonica

$156910030031 \overline{1} 1113111112100122101000110111111111111111101$

1570 Willemia namibiae 0000000110011011010?1?02310000010011010000?100100?01

1571 Willemia nadchatrami

$157210030031 \overline{1} 111311111010012210000011011111$ ?0111111??101

1573 Willemia multilobata

$157400000201 \overline{1} 00100 ?$ ? 010100011100000000000000010100100001

1575 Willemia meybholae 0222222111112111013101023100001111111110110100111011

1576 Willemia koreana 1000220110001011010100011101000110110100010000100001

1577 Willemia_japonica 1002222110010011010100011101000110010110110100100011

1578 Willemia_iztaccihuatlensis

$157911000001 \overline{1} 00010110101000$ [12][12]1010011101101?01100?0100001

1580 Willemia intermedia

$158113000001 \overline{1} 0010011010100011101000110000110110100100001$

1582 Willemia granulata 1000220110010011010100011101000110000110110100100011

1583 Willemia unispina 100000001??10011?101000111111101101101001100001??011

1584

1585

1586

1587

1588

1589

1590

1591

1592

1593

1594

1595 Willemia_fjellbergi

$13322221 \overline{1} 001001101010001110100011000011011$ ?1?1100011

Willemia elisabethum

$1111211 \overline{1} 0010011110101011101001110111110110101100011$

Willemia dubia 1000000110001011010100011101000110110100010000100001

Willemia_denisi 1111111110010011110101011101001110111110110101100011

Willemia_delamarei 100300311????1110121001??11111011011111111 ????1 ?? 01

Willemia deharvengi

$20030031 \overline{1} 1113111013100123111110110111111110111111111$

Willemia_christianseni

$13000001 \overline{1} 0001011010100011101000110010100010000100001$

Willemia buddenbrocki

$159610030031 \overline{1} 1113111112100133101000110111111110111111101$ 
1601

1602

1603

1604

1605

1606

1607

1608

1609

1610

1611

1612

1613

1614

1615

1616

1617

1618

1619

1620

1621

1622

1623

1624

1625

1626

1627

1628

1629

1630

1631

1632

1633

1634

1635

1636

1637

1638

1639

1640

1641

1642

1643

1644

1645

1646

1647

1648

1649

1650

1651

1652

1653

Willemia_brevispina

$13032031 \overline{1} 1113111110100122101000110111111111111111101$

Willemia bellingeri

$00000201 \overline{1} 0010011010100011100000000000000010100100001$

Willemia bedosae 1000000110001011010100011101000110110100110000100001

Willemia_arida 1332222110?100110101000??101000110000110110101100011

Willemia_nosyboraha

$10030031 \overline{1} 11$ ??111111100133111110110111111110010????01

Willemia arenicola 022222211102111012101023100001111111110110100111001 Willemia anophthalma

$10000001 \overline{1} 0001011010100011101000100010100010000100001$

Willemia_annapurna 1003003111113111013100133101000110111111110111111101

Xenyllogástrura octoculata

$00000001000 ? 010 \overline{0} 00000101100000000000010010 ? 1000 ? 0000$

Orogastrura dilatata

$00000000000 \overline{0} 00000000000000000000000101000101000 ? ? 000$

Hypogastrura_vernalis

$000000000 ? 000000000000000000000000000000010$ ? ??000000

;

$\mathrm{CC}-0.51$

;

proc /;

\#

\$

;

Cn $\{0$ willemia2011.ss:0 A B C D E F G H I J K L M N O P Q R S T U V 01 $2 \quad 3 \quad 4 \quad 5 \quad 67889$;

\{1 willemia2011.SS:1 A B C D E F G H I J K L M N O P Q R S T U V 0112 3456789 ;

\{2 willemia2011.ss:2 A B C D E F G H I J K L M N O P Q R S T U V 0112 3456789 ;

\{3 willemia2011.s.S:3 A B C D E F G H I J K L M N O P Q R S T U V 0112

3456789 ;

\{4 willemia2011.ss:4 A B C D E F G H I J K L M N O P Q R S T U V 0

3456789 ;

\{5 willemia2011.ss:5 A B C D E F G H I J K L M N O P Q R S T U V 012

3456789 ;

\{6 willemia2011.SS: 6 A B C D E F G H I J K L M N O P Q R S T U V 0112

3456789 ;

$\{7$ willemia2011.ss:7 A B C D E F G H I J K L M N O P Q R S T U V 0112 $\begin{array}{llllllll}3 & 4 & 5 & 6 & 7 & 8 & 9\end{array}$

\{8 willemia2011.SS: 8 A B C D E F G H I J K L M N O P Q R S T U V 0112

3456789 ;

\{9 willemia2011.ss: 9 A B C D E F G H I J K L M N O P Q R S T U V 0112 3456789 ;

\{10 willemia2011.ss:10 A B C D E F G H I J K L M N O P Q R S T U V 01 23456789 ;

\{11 willemia2011.ss:11 A B C D E F G H I J K L M N O P Q R S T U V 01 23456789 ;

\{12 willemia2011.SS:12 A B C D E F G H I J K L M N O P Q R S T U V 01 23345678 (

\{13 willemia2011.ss:13 A B C D E F G H I J K L M N O P Q R S T U V 01 23456789 ;

\{14 willemia2011.SS:14 A B C D E F G H I J K L M N O P Q R S T U V 01 23456789 ;

\{15 willemia2011.ss:15 A B C D E F G H I J K L M N O P Q R S T U V 01 234567689 ; 


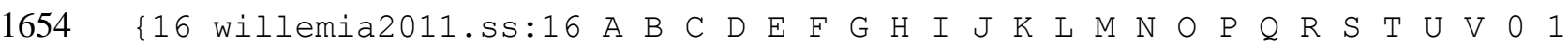
$165523 \quad 456789$;

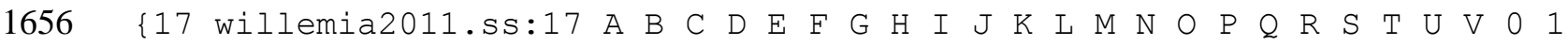
$1657 \quad 2 \quad 3 \quad 4 \quad 56789$;

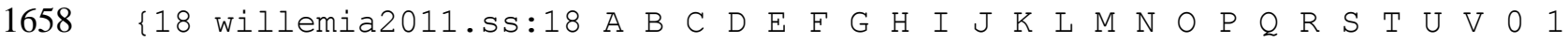
165923456789 ;

$1660\{19$ willemia2011.SS:19 A B C D E F G H I J K L M N O P Q R $\quad S \quad T \quad U$ V 01 $1661 \quad 2 \quad 3 \quad 4 \quad 56789$;

$1662\{20$ willemia2011.ss:20 A B C D E F G H I J K L M N O P Q R S T U V 01 166323456789 ;

$1664\{21$ willemia2011.SS:21 A B C D E F G H I J K L M N O P $Q 2$ R 166523456789 ;

$1666\{22$ willemia2011.ss:22 A B C D E F G H I J K L M N O P Q R S T U V 01 166723456789 ;

$1668\{23$ willemia2011.ss:23 A B C D E F G H I J K L M N O P Q R $\mathrm{S}$ T U V 0 166923456789 ;

$1670\{24$ willemia2011.SS:24 A B C D E F G H I J K L M N O P Q R $\quad$ S T U V 167123456789 ;

$1672\{25$ willemia2011.ss:25 A B C D E F G H I J K L M N O P Q R S T U V 0 1673253456789 ;

$1674\{26$ willemia2011.ss:26 A B C D E F G H I J K L M N O P Q R $\mathrm{S}$ T U V 0 167523456789 ;

$1676\{27$ willemia2011.ss:27 A B C D E F G H I J K L M N O P Q R $\mathrm{S}$ T U V 0 167723456789 ;

$1678\{28$ willemia2011.SS:28 A B C D E F G H I J K L M N O P Q R $\mathrm{S}$ T U V $167923 \quad 456789$;

$1680\{29$ willemia2011.s. 29 A B C D E F G H I J K L M N O P Q R S T U V 01 1681

1682 23456789 ;

\{30 willemia2011.sS:30 A B C D E F G H I J K L M N O P Q R S T U V 01 $1683 \quad 2 \quad 3 \quad 4 \quad 5 \quad 6788$;

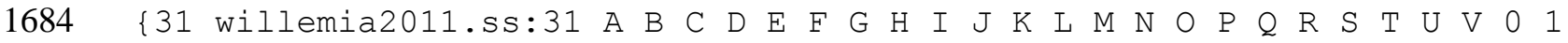
168523456789 ;

$1686\{32$ willemia2011.ss:32 A B C D E F G H I J K L M N O P Q R S $\mathrm{T}$ U V 0 168723456789 ;

$1688\{33$ willemia2011.ss:33 A B C D E F G H I J K L M N O P Q R S T U V 01 168923456789 ;

$1690 \quad\{34$ willemia2011.sS:34 A B C D E F G H I J K L M N O P $Q$ 169123456789 ;

$1692\{35$ willemia2011.SS:35 A B C D E F G H I J K L M N O P Q R $\quad$ S T U V 0 169323456789 ;

$1694\{36$ willemia2011.ss:36 A B C D E F G H I J K L M N O P Q R $\mathrm{S}$ T U V 169523456789 ;

$1696\{37$ willemia2011.ss:37 A B C D E F G H I J K L M N O P Q R $\quad$ S T U V 169723456789 ;

$1698\{38$ willemia2011.SS:38 A B C D E F G H I J K L M N O P Q R S T U V 0 169923456789 ;

$1700\{39$ willemia2011.SS:39 A B C D E F G H I J K L M N O P Q R $\quad$ S T U V 170123456789 ;

$1702\{40$ willemia2011.ss:40 A B C D E F G H I J K L M N O P Q R 170323456789 ;

$1704\{41$ willemia2011.SS:41 A B C D E F G H I J K L M N O P Q $170523 \quad 456789$;

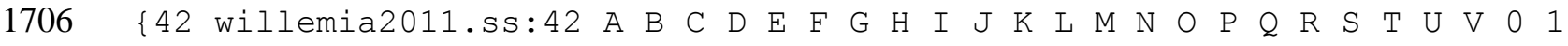
$1707 \quad 2 \quad 3 \quad 4 \quad 56789$;

$1708\{43$ willemia2011.ss:43 A B C D E F G H I J K L M N O P Q R S T U V 01 170923456789 ;

$1710\{44$ willemia2011.ss:44 A B C D E F G H I J K L M N O P Q R $\mathrm{S}$ T U V 0 $171122 \quad 3 \quad 4 \quad 566768$; 
$1712\{45$ willemia2011.ss:45 A B C D E F G H I J K L M N O P Q $R$ $\begin{array}{llllllllll}1713 & 2 & 3 & 4 & 5 & 6 & 7 & 8 & 9\end{array}$;

$1714\{46$ willemia2011.ss:46 A B C D E F G H I J K L M N O P $Q$ Q $R$ 171523456789 ;

$1716\left\{\begin{array}{l}47 \\ \text { willemia2011.SS: } 47 \text { A }\end{array}\right.$ $\begin{array}{llllllllll}1717 & 2 & 3 & 4 & 5 & 6 & 7 & 8 & 9\end{array}$;

$1718\{48$ willemia2011.SS: 48 A B C D E F G H I J K L M N O P $Q$ Q $R$ 171923456789 ;

$1720 \quad$ 4 49 willemia2011.SS:49 A B C D E F G H I J K L M N O P $Q$ 1721253456789 ;

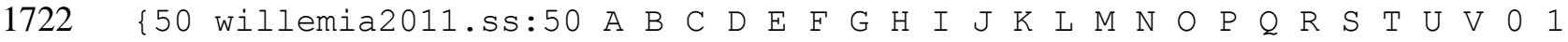

$1723 \quad 2 \quad 3 \quad 4 \quad 56789$;

$1724\{51$ willemia2011.SS:51 A B C D E F G H I J K L M N O P Q

tread (Hypogastrura_vernalis (Orogastrura_dilatata (Xenyllogastrura_octoculata ( Willemia_multilobata Willemia_bellingeri) ( (Willemia trilob̄ata Willemia namibiae) ( Willemia similis ( Willemia_christianseni Willēemia_anophthalma) ((Wīllemia_dubia (Willemia_scandinavica Willemia_koreana)) (Willemia_iztaccihuatlensis (Willemia_bedosae ( Willemia_unispina Willemia_psammophila) $($ Willemia_virae Willemai_talī)))))) (Willemia_intermedia (Willemia_shanghaiensis (Willemia_granulata (( (Willemia_fjellbergi Willemia_āida) (Willemia_trisphaērae (Willemia_elisabethum Willemia denisi))) (Willemia japonica (Willemia subbulbosa (( (Willemia_persimilis Willemia_acantha) (Willemia_bulbosa (Willemia meybholae Willemia arēnicola)) ) ((Willemīa nepalensis (Willemia_neocaledonica (Wil̄̄emia_nadchatrami Willemīa_brevispina))) (Willemia annapurna (Willemia buddenbrocki (Willemia wāndae (Willemia_nosyboraha (Willemiādelamarei (Willemia_sētonychia Willemia_deharvengi)) )) )) )) ) ) ) ) )) )) )) ) * (Hypogastrura_vernalis (Orogastrura_dilatata (Xenyllogastrura_octoculata ( (Willemia_mültilobata Willemia_bellingeri) ((Willemia_trilobata Willemia_nāmibiae) ( Willemia_similis ( Willemia_christ̄ianseni Willemia anophthalma) ( Willemia dubia (Willemia scandinavica Willemia_koreana)) ((Willemia_virae (Willemia_unispina Willemia psammophila)) (Willemia bedosae (Willemia iztaccihuatlensis Willemai_tali))))) (Willemia_intermedia (Willemia_shanghaiensis (Willemiā granulata (( Willemīa fjellbergi Willemīa arida) (Willemia_trisphaerae (Willemia_elisabethum Willemiā_denisi))) (Willemia_japonica (Willemia_sub̄bulbosa ( (Willemia_persimilis Willemia_acantha) (Willemia_bulbosa (Willemia_meybhōlae Willemia_arenicola)) ( Willemia_nepalensis (W̄illemia_neocaledonica (Willemī̄ nadchatrami Willemia brevispina))) (Willemīa annapurna (Willemia_buddenbrocki (Willemīa_wandae (Willemia_nosyb̄oraha (Willemia_delamarei (Willemia_setonychia Willemia_(eharvengi))) ) ) ) ) ) ) ) ) ) )) )) ) ) * (Hypogastrura_vernalis (Orogastrura_dilatata (Xenyllogastrura_octoculata ( (Willemia_mūltilobata Willemia_bellingeri) ((Willemia_trilobata Willemia_nāmibiae) ((Willemia_similis (Willemia_christīanseni (Willemiāanophthalma (Willemīa_dubia ( Willemiā_scandinavica Willemia_koreana) ( Willemia_unispina Willemia_psammophila) (Willemia_bedosae (Willemia_iztaccihuatlensis (Willemia_virae Willemai_tali))))))) ) (Willemia_intermedia (Willemia_shanghaiensis (Willemiā granulata (Willemia fj̄ellbergi (Willemia ā̌ida (Willemia_trisphaerae (Willemiāelisabethum Willemiādenisi)))) (Willemia_japonica (Willemia_sub̄bulbosa (( Willemia_persimilis 
1770 Willemia_acantha) (Willemia_bulbosa (Willemia_meybholae Willemia_arenicola))) ((Willemia_nepalensis ('Willemia_nosyboraha Willemia_delamarei) (Willemia_setonychia Willemia_deharvengi))) (Willemiā_annapurna (Willemia_buddenbrocki (Willē̄ia_wandae (Willemia neocaledonica (Willēemia nadchatrami

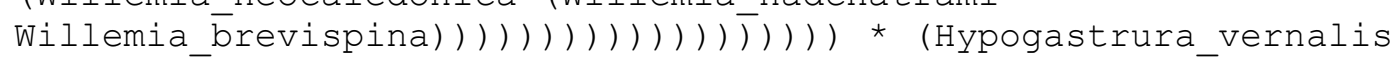
(Orogastrura_dilatata (Xenyllogastrura_octoculata ((Willemia_mültilobata Willemia_bellinḡeri) ((Willemia_trilobata Willemia_nämibiae) ((Willemia_similis (Willemia_christíanseni (Willemiāanophthalma ((Willemia_scandinavica Wìllemia_koreana) (Willemia_dubia ((Willemia_unispina Willemia_psammophīa) (Willemia_virae (Willemia_bedosae (Willemia_íztaccihuatlensis Willemai tali)))l)l)) (Willemia intermedia (Willemia shanghaiensis (Willemiā granulata ((Willemia fjellbergi Willemia āida) (Willemia_trisphaerae (Willemia_elisabethum Willemiā_denisi))) (Willemia_japonica (Willemia_sub̄bulbosa (( Willemia_persimilis Willemia_acantha) (Willemia_bulbosa (Willemia meybholae Willemia_arenicola))) ((Wilīemia_nepalensis ('Willemia_nosyboraha Willemia delamarei) (Willemia sē̄onychia Willemia dehārvengi))) (Willemiāannapurna (Willemia_buddenbrocki (Willemia_wandae (Willemia neocaledonica (Willemia nadchatrami

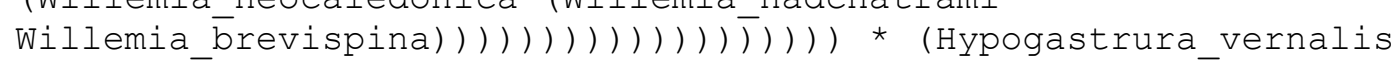
(Orogastrura_dilatata (Xenyllogastrura_octoculata ((Willemia multilobata Willemia_bellingeri) ((Willemia trilobata Willemia_nämibiae) ((Willemia_similis (Willemia_christīanseni (Willemiā_anophthalma ( Willemia_scandinavica Willemia_koreana) (Willemia_dubia (Willemia_virae ( Willemia_iztaccihuatlensis Willemia_bedosae) (Willemāi tali (Willemia_unispina Willemia_psammophila)))l))/)) (Willemia_intermedia (Willemiāshanghaiensis (Willemia_granulata ((Willemia_fjellbergi (Willemia_arida (Willemia_trisphaêrae (Willemia_elisabēthum Willemia_èenisi))) (Willemia_japonica (Willemia_subbulbosa ( (Willemia_persimilis Willemia_acantha) (Willemía_bulbosa (Willemia_meybholae Willemia_arēnicola))) ((Willemia_nepalensis (Willemia neocaledonica (Willemia nadchatrami Willemía brevispina))) (Willemia_annapurna (Willemia_buddenbrocki (Willemia_wāndae (Willemia_nosyboraha (Willemiādelamarei (Willemia_sētonychia

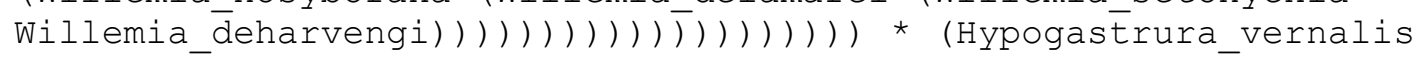
(Orogastrura_dilatata (Xenyllogastrura_octoculata ((Willemia_mültilobata Willemia_bellingeri) ((Willemia_trilobata Willemia_nämibiae) ((Willemia_similis (Willemia_christíanseni (Willemīāanophthalma (Willemīa_dubia (Willemīa_scandinavica Willemia_k̄oreana) ( Willemia_izĒaccihuatlensis Willemia_bedosae) (Willemiāvirae (Willemai tali (Willemia_unispina Willemia_psammophila))))(J))) (Willemia_intermedia (Willemiāshanghaiensis (Willemia_granulata (Willemia_fjellbergi (Willemia_arida (Willemia_trisphaerae (Willemia_elisabēthum Willemia_denisi))) (Willemia_japonica (Willemiāsubbulbosa (( (Willemia_persimilis Willemia_acantha) (Willemía_bulbosa (Willemia_méybholae Willemia_arēnicola))) ((Willemía_nepalensis ( (Willemiānosyboraha Willemīa_delamarei) (Willemia_setonychia Willemia_deharvengi))) (Willemia annapurna (Willemiā_buddenbrocki (Willemiā_wandae (Willemia_neocāedonica (Willemia_nādchatrami

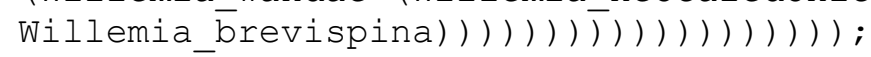


1826

1827

1828

1829 bremer_w.sh:

1830

1831

1832

1833

1834

1835

1836

1837

1838

1839

1840

1841

1842

1843

1844

1845

1846

1847

1848

1849

1850

1851

1852

1853

1854

1855

1856

1857

1858

1859

1860

1861

1862

1863

1864

1865

1866

1867

1868

1869

1870

will-one.tre: a

i) )) ) )

bremer_w.sh and jackknife_w.sh are the scripts for bremer and jackknife calcultion respectively; willone.tre file contains one of the six optimal tree for the purpose of these calculations;

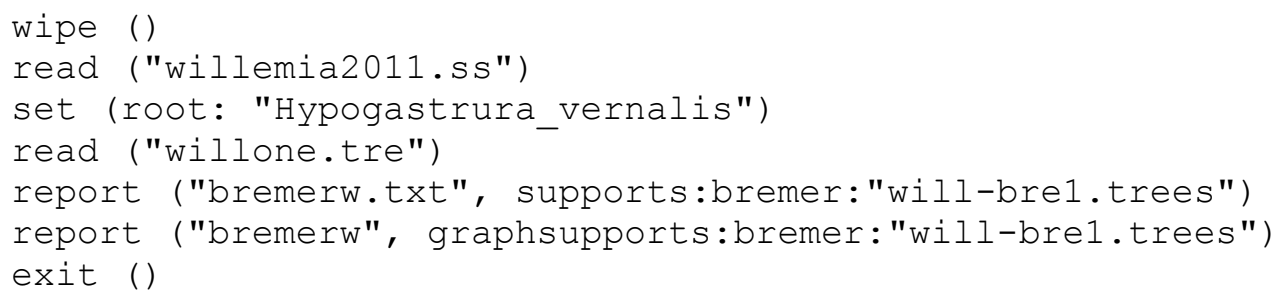

(Hypogastrura vernalis, (Orogastrura dilatata, (Xenyllogastrura octoculat

, ( Willemia_multilobata,Willemia_bellingeri), ((Willemia_trilobata

,Willemia nāmibiae), ( (Willemia similis, ( Willemia christianseni

,Willemia anophthalma), ( (Willemia dubia, (Willemia scandinavica

,Willemia koreana)), (Willemia iztāccihuatlensis, (W̄illemia bedosae

,( (Willemía_unispina,Willemia_psammophila), (Willemia_virae, Willemai_tal

)), (Willemia intermedia, (Willemia shanghaiensis, (Willemia granulata

, ( (Willemia f́jellbergi,Willemia ārida), (Willemia trisphaērae

, (Willemia_elisabethum,Willemia_denisi))), (Willemía_japonica

, (Willemia_subbulbosa, ( (Willemia persimilis,Willemia acantha)

, (Willemia_bulbosa, (Willemia_meybholae,Willemia_arenic̄ola)))

, (Willemiānnepalensis, (Willēemia_neocaledonica, (Willemia_nadchatrami

,Willemia brevispina))), (Willemiā annapurna, (Willemia bū denbrocki

, (Willemiā wandae, (Willemia nosybōraha, (Willemia delāmarei

,(Willemia_setonychia,Willemia_deharvengi)))))) )) )) )) )) )) ) )) [154.]; 
1871

1872

1873

1874

1875

1876

1877

1878

1879

1880

1881

1882

1883

1884

1885

1886

1887

1888

1889

1890

1891

1892

\section{$\underline{\text { Appendix S1d: Willemia phylogeny and characters: results }}$}

Figure Appendix S1 shows the strict consensus of 6 most parsimonious trees with a tree length of 154 steps, with jacknife and Bremer indices indicated at each node. Consistency Index is 46 and Retention Index is 82 . All trees, jackknife, statistics and Bremer supports can be found in Electronic Appendix S1c. The addition of the 5 new Willemia species did not change the general topology found in D'Haese (2000). The monophyly of the genus Willemia was confirmed and strongly supported (jackknife resampling percentage of $100 \%$ and Bremer support value 3). The anophthalma, denisi s.str. and buddenbrocki groups were retrieved monophyletic again and the denisi group sensu Potapov is still paraphyletic (with the addition of W. shanghaiensis between W. intermedia and W. granulata in a paraphyletic assemblage). The new species (for the analysis) W. tali, W. iztaccihuatlensis, W. psammophila and W. unispina belong to the anophthalma group. W. acantha is sister group to W. persimilis, in the same group, W. bulbosa is sister group to W. arenicola $+W$. meybholae. Lastly, W. nosyboraha is included in the buddenbrocki group. Table 1 and Table in Appendix S2e show biogeographic and ecological attributes of species, respectively. In these tables species were arranged in the order given by the phylogeny.

\section{REFERENCES}

D’Haese, C. (2000) Is psammophily an evolutionary dead end? A phylogenetic test in the genus Willemia (Collembola: Hypogastruridae). Cladistics, 16, 255-273. 
1893 Figure Appendix S1. Strict majority consensus of six phylogenetic trees of the genus

1894

1895

1896 respectively.

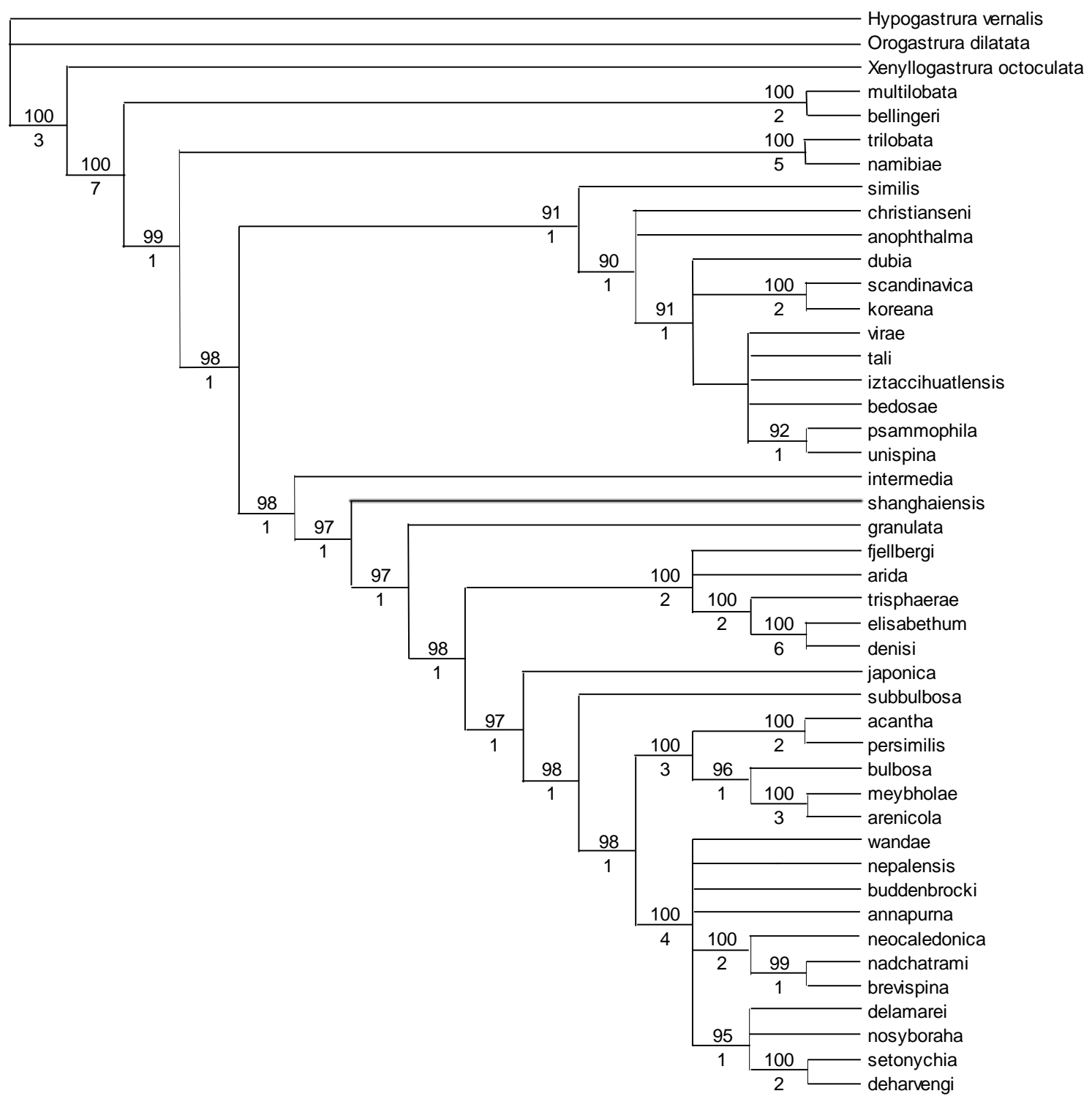


1899

1900

1901

1902

1903

1904

1905

1906

1907

1908

1909

1910

1911

1912

1913

1914

- 'saline' was defined as a soil with a high osmotic pressure due to a high charge in salts

1918 (beaches and salt deserts).

1919 Every species could be assigned to several harsh habitats according to $(i)$ multiple records of 1920 the same species in a variety of habitats, or (ii) habitats belonging to several harshness

\section{Appendix S2: Literature research: definitions, references, exploration of biases}

\section{$\underline{\text { Appendix S2a - Definitions of factors of harshness }}$}

- 'xeric' was defined as an environment displaying permanent or seasonal aridity: deserts (whether warm or cold), matorrals, sand dunes with poor vegetation cover, karst landscapes and dry Mediterranean areas

- 'hydric' was defined as an environment displaying excess of water and associated lack of soil atmosphere: waterlogged soils, flooded areas

- 'arctic' was defined as an environment displaying a long period of frost, generally more than six months, reflecting a latitudinal temperature gradient: polar, arctic and subarctic environments

- 'alpine' was defined as an environment displaying a long period of frost, generally more than six months, reflecting an altitudinal temperature gradients: high mountains, including alpine and subalpine climates, above 1,000 $\mathrm{m}$ in nordic countries, above 2,000 $\mathrm{m}$ in temperate areas, above 3,000 or $4,000 \mathrm{~m}$ in tropical areas

- 'acid' was defined as a soil at $\mathrm{pH}_{\text {water }}$ less than 5, where free aluminium and high phenolic concentrations are likely to occur: raw humus, podzols

- 'metallic' was defined as a soil polluted with heavy metals: areas in the vicinity of smelter or mining activities 
1921 categories. For instance, over the whole array of literature consulted, the same species can be

1922

1923

1924

1925

1926

1927

1928

1929

1930

1931

1932

1933

1934

1935

1936

1937

1938

1939

1940

recorded both in waterlogged and arid soils or the same habitat can be 'arctic' and 'acid', but only when this was indicated. In our census we did not try to discern whether some factors were dominant above others in a given record unit. Rather we considered them as independent causes of harshness, with which species must cope within a given habitat throughout their evolutionary history (Jablonski, 2008).

Caves were excluded given that $(i)$ they constitute refuges where more sensitive species can live in a more buffered environment, whatever the nature of the surrounding environment, (ii) there was no evidence they were detrimental to growth and reproduction of most soil invertebrate species (Moseley, 2007), and (iii) some Willemia species were reported to occur in caves (some of them were even described for the first time in caves) but they were also found in other environments, suggesting the absence of specialisation for cave life in this genus (Christiansen, 1965). Psammophily sensu D’Haese (2000), i.e. life in sand, was partitioned in 'saline' and 'xeric' categories according to whether sea water or drought was the prevailing factor. For instance seashore dunes were considered 'xeric' but not 'saline' while the intertidal zone was considered 'saline' but not 'xeric'. Experimental studies focusing on individual Willemia species as well as on entire soil communities were also taken into account. The 'harshness breadth' index was estimated for every species by the number of harsh environments in which the species was recorded, thus scaling from 0 (no harsh environment recorded for the species) to 7 (all harsh environments recorded).

Obviously, no place on earth will show all types of harshness. This is why we considered multiple types of harshness, and why we quantified the harshness breadth as the number of harshness types occupied by a given species. Moreover, we tested whether occupation of different types of harshness is positively or negatively correlated, i.e. whether species that can tolerate certain kinds of harsh environments tend to be able to tolerate a broad 
1946

1947

1948

1949

1950

1951

1952

1953

1954

1955

1956

range of harsh environments (except those affected by salinity). We found that occupations of all but one type of harshness are positively correlated (Results). This means that a species that is found in environments that are harsh in one type tend to be found under different types of harsh environments, too. Inversely, other species occupy environments lacking any of the types of harshness. This result justifies talking broadly about "species using harsh environments" as we repeatedly do it.

The largest possible corpus of literature was examined for the assessment of use of harsh environments in Willemia species. As defined above (Introduction), harsh environments are those which limit the rate of growth and reproduction of most species, except a few ones tolerating it. This does not mean that harsh environments are poorer in Collembolan individuals, since better adapted species may benefit from the alleviation of competition caused by the resulting decrease in species richness and thereby may locally proliferate (Usher, 1985). A total of 248 references were used for the census (Appendix S2b). Languages available to us were English, French, German, Italian, Portugese and Spanish, embracing most literature published in books and scientific journals. Other languages (Russian, Japanese, Hungarian) were cautiously discarded, in order to avoid misinterpretation, but they comprised less than $1 \%$ of published literature. When information about soil or climate was not given for a record, but the plant community was sufficiently described in the vicinity of the sample, then vegetation was used as a basis for estimating the harshness of the environment: in several instances dominant ericaceous or coniferous vegetation was considered as indicative of soil acidity given the recalcitrance of its litter and its known acidifying influence on the environment occupied by Willemia (Ponge, 2000), while grassland species were indicative of more fertile and less acid soils (Miles, 1985; Falkengren-Grerup, 1986). In two instances, the geographic locality was sufficiently precise and was used to derive environmental conditions 
1970 prevailing at the sampling site. In the absence of any clue on environmental conditions,

1971 records were disregarded.

The above classification might miss species that are able to use harsh environments

1973

1974

1975

1976

1977

1978

1979

1980

1981

1982

1983

1984

1985

1986

1987

1988

1989

\section{REFERENCES}

Christiansen, K. (1965) Behavior and form in the evolution of cave Collembola. Evolution, 19, 529-537.

D'Haese, C. (2000) Is psammophily an evolutionary dead end? A phylogenetic test in the genus Willemia (Collembola: Hypogastruridae). Cladistics, 16, 255-273.

Falkengren-Grerup, U. (1986) Soil acidification and vegetation changes in deciduous forest in southern Sweden. Oecologia, 70, 339-347.

Jablonski, D. (2008) Extinction and the spatial dynamics of biodiversity. Proceedings of the National Academy of Sciences of the United States of America, 105, 11528-11535.

Miles, J. (1985) The pedogenic effects of different species and vegetation types and the implications of succession. Journal of Soil Science, 36, 571-584. 
1990 Moseley, M. (2007) Acadian biospeleology: composition and ecology of cave fauna of Nova

1991

1992

1993

1994

1995

1996

1997

1998 Scotia and southern New Brunswick, Canada. International Journal of Speleology, 36, $1-21$.

Ponge, J.F. (2000) Vertical distribution of Collembola (hexapoda) and their food resources in organic horizons of beech forests. Biology and Fertility of Soils, 32, 508-522.

Usher, M.B. (1985) Population and community dynamics in the soil ecosystem. Ecological interactions in soil: plants, microbes and animals (ed. by A.H. Fitter, D. Atkinson, D.J. Read and M.B. Usher), pp. 243-265.. Blackwell, Oxford. 
1999 Appendix S2b - References used for the assessment of use of harsh environments in Willemia

2000 species.

acantha $\quad 1 \quad$ Bonet (1945)

annapurna 2 d'Haese \& Weiner (1998), Thibaud (2004)

anophthalma 156 Handschin (1924), Marlier (1942), Gisin (1943, 1947), Weber (1950), Haybach (1959), Gisin (19 (1961), Cassagnau \& Rapoport (1962), Hüther (1962), Agrell (1963), Petersen (1965), Hale (19l (1967), Stebaeva (1967), Nosek (1967), Rusek (1968), Usher (1970), Jahn (1972), Gough (197: (1973), Axelsson et al. (1973), Blackith (1974), Kaczmarek (1975a, b), Dunger (1975), Usher (1 (1976), Fjellberg (1976), Ryan (1977), Lohm et al. (1977), Persson \& Lohm (1977), Loksa (1978 (1979), Petersen (1980), Ponge (1980), Hutson (1980a, b), Abrahamsen et al. (1980), Bååth et \& Kjøndal (1981a, b), Izarra (1981), Hågvar (1982), Ponge \& Prat (1982), Huhta et al. (1983), G (1983), Ponge (1983), Hågvar (1983, 1984a, b), Hågvar \& Abrahamsen (1984), Poursin \& Pong al. (1984), Axelsson et al. (1984), Fjellberg (1984, 1985), Arbea \& Jordana (1985a, 1986), Fjellb et al. (1986), Pozo (1986), Ardanaz \& Jordana (1986), Poinsot-Balaguer \& Tabone (1986), Pozc Huhta et al. (1986), Vilkamaa \& Huhta (1986), Bolger (1986), Ponge et al. (1986), Kuznetsova ( \& Greven (1987), Hågvar (1987), Melecis (1987), Bengtsson \& Rundgren (1988), Fjellberg (198 (1988), Pichard et al. (1989), Arbea \& Jordana (1989, 1990), Hågvar \& Abrahamsen (1990), Má (1991), Gerdsmeier \& Greven (1992), Ponge (1993), Babenko (1994), Kopeszki \& Meyer (1994) Trockner (1994), Hågvar (1994), Rusek (1994), Fjellberg (1994), Lauga-Reyrel \& Lauga (1995), Deharveng \& Lek (1995), Koehler et al. (1995), Salminen et al. (1995), Rusek (1996), Shaw \& Deharveng (1996), Kopeszki \& Meyer (1996), Haimi \& Siira-Pietikäinen (1996), Filser \& Hölsche et al. (1997), Fjellberg (1998), Therrien et al. (1999), Traser (1999), Sławska (2000), Ponge (20 et al. (2000a, b, 2001a, b), Loranger et al. (2001), Ojala \& Huhta (2001), Siira-Pietikäinen et al. (2002), Kuznetsova (2002), Pflug \& Wolters (2002), Babenko (2002), Lek-Ang \& Deharveng (20 Ponge (2002), Shrubovych (2002), Ponge et al. (2002, 2003), Chauvat et al. (2003), Stebaeva ( (2003a, b), Gruia (2003), Cassagne et al. (2003, 2004), Lindberg \& Persson (2004), Materna (2 (2004), Petersen et al. (2004), Garnier \& Ponge (2004), Gillet \& Ponge (2004), Dunger et al. (20 (2004), Lindberg \& Bengtsson (2005), Kuznetsova (2006), Traser \& Horváth-Szováti (2006), Hu Syrek et al. (2006), Ponge et al. (2006), Sleptzova \& Reznikova (2006), Chauvat et al. (2007), J (2007), Hopkin (2007), Raschmanová et al. (2008), Salamon et al. (2008), Mordkovich et al. (20 (2008, 2009), Auclerc et al. (2009), Salamon \& Alphei (2009), Sławska \& Sławski (2009)

arenicola $\quad 2 \quad$ Palacios-Vargas \& Vázquez (1988), Palacios-Vargas \& Thibaud (2001)

arida $\quad 2 \quad$ Fjellberg (1991), Addison et al. (2006)

bedosae $\quad 3 \quad$ d'Haese (1998), Thibaud (2004), Raschmanová et al. (2008)

bellingeri $\quad 1 \quad$ Palacios-Vargas \& Vázquez (1988)

brevispina $\quad 10$

Hüther (1962), Rapoport (1962), Palacios-Vargas (1987), Najt et al. (1990), Christiansen \& Belli Thibaud (1993), d'Haese \& Weiner (1998), Thibaud \& Palacios-Vargas (1999), Culik \& Zeppelin al. (2006)

buddenbrocki 19 Hüther (1959, 1962), Rapoport \& Rubio (1963), Gough (1972), Ponge (1983), Arpin et al. (1984 al. (1985), Fjellberg (1992), Ponge (1993), Sabatini et al. (1997), Jordana et al. (1997), Rebecch Ponge (2000a), Chauvat \& Ponge (2002), Gómez-Anaya \& Palacios-Vargas (2004), Thibaud (2 Ponge (2005), Hopkin (2007)

bulbosa 2 Bonet (1945), Cutz-Pool et al. (2007)

christianseni 1 d'Haese (1998)

deharvengi 1 d'Haese \& Weiner (1998)

delamarei 1 Prabhoo (1971)

denisi $\quad 77$

Gisin (1960), Cassagnau (1961), Hüther (1962), Petersen (1965), Szeptycki (1967), Nosek (196 Bödvarsson (1973), Axelsson et al. (1973), Fjellberg (1976), Bonnet et al. (1976, 1979), Hutson Lienhard (1980), Bååth et al. (1980), Ponge \& Prat (1982), Hågvar (1982, 1983), Gers \& Izarra Kannowski (1984), Hågvar \& Abrahamsen (1984), Axelsson et al. (1984), Fjellberg (1984, 1985) Jordana (1985b, 1986), Pozo et al. (1986), Bolger (1986), Kuznetsova (1987), Melecis (1987), E Rundgren (1988), Fjellberg (1988), Arbea \& Jordana (1989), Gerdsmeier \& Greven (1992), Batt (1993), Kopeszki \& Meyer (1994), Kopeszki \& Trockner (1994), Lopes \& da Gama (1994), Deha (1995), Rusek \& Marshall (1995), Rusek (1996), Deharveng (1996), Jordana et al. (1997), Fjellb 
dubia 3

elisabethum

fjellbergi 3

granulata 3

intermedia $\quad 60$

iztaccihuatlen 2

sis

japonica

koreana

meybholae

multilobata

nadchatrami 2

namibiae 1

neocaledonica 5

nepalensis 2

nosyboraha 1

persimilis 6

psammophila

scandinavica 34

setonychia 1 shanghaiensis 1

similis

subbulbosa

tali

trilobata

trisphaerae

unispina

virae

wandae (2000b), Ojala \& Huhta (2001), Loranger et al. (2001), Chagnon et al. (2001b), Babenko (2002) (2002), Addison et al. (2003), Babenko (2003a, b), Ponge et al. (2003), Cassagne et al. (2003, (2004), Garnier \& Ponge (2004), Gillet \& Ponge (2004), Koolhaas et al. (2004), Thibaud (2004), (2006), Syrek et al. (2006), Sørensen et al. (2006), Traser \& Horváth-Szováti (2006), Addison e Chahartaghi et al. (2006), Ponge et al. (2006), Kuznetsova (2006, 2007), Chauvat et al. (2007), (2008), Babenko (2008), Raschmanová et al. (2008), Salamon \& Alphei (2009), Auclerc et al. (2 Christiansen \& Bellinger (1980), Benner \& Kannowski (1984), d'Haese (1998)

Weiner (1986)

Babenko (2003a, b), Thibaud (2004)

Fjellberg $(1984,1985)$, Addison et al. (2006)

Mills (1934), Bellinger (1954), Hüther (1962), Wray et al. (1963), Szeptycki (1967), Gough (1972 Huhta et al. (1979), Lienhard (1980), Ponge \& Prat (1982), Ponge (1983), Arpin et al. (1984), Pc (1984), Arbea \& Jordana (1986), Bolger (1986), Weiner (1986), Luciáñez Sánchez \& Simón Ber (1988), Simón Benito \& Pozo Martínez (1988), Fjellberg (1988), Sterzynska (1989), Arbea \& Jor Rusek (1990), Zerling (1990), Sterzinska (1990), Palacios-Vargas (1990), Fjellberg (1992), Pon Battigelli \& Marshall (1993), Kováč \& Miklisová (1995), Rusek \& Marshall (1995), Filser (1995), (1997), Jordana et al. (1997), da Gama et al. (1997, 1998), Fjellberg (1998), Barrocas et al. (19) (1999), Ponge (2000a), Loranger et al. (2001), Otrysko \& Pagé (2001), Shrubovych (2002), Tras Stebaeva (2003), Addison et al. (2003), Ponge et al. (2003), Petersen et al. (2004), Dunger et a (2004), Kováč et al. (2005), Gillet \& Ponge (2005), Traser \& Horváth-Szováti (2006), Addison et et al. (2006), Sleptzova \& Reznikova (2006), Debeljak et al. (2007), Hopkin (2007), Raschmano Babenko (2008)

García-Gómez \& Cutz-Pool (2008), García-Gómez et al. (2009)

Tanaka \& Kitazawa (1982), Thibaud (2004)

2 Thibaud \& Lee (1994), Thibaud (2004)

Palacios-Vargas (1987)

Gers \& Deharveng (1985), Fjellberg (1992, 1998), Babenko (2003a, b), Sterzynska \& Bolger (2C (2004), Hopkin (2007)

Yosii (1959), McClure et al. (1967)

Thibaud \& Massoud (1988)

Weiner (1991), d'Haese \& Weiner (1998), Thibaud (2002, 2009a, b)

d'Haese \& Weiner (1998), Thibaud (2004)

Thibaud (2008)

Bonet (1945), Hüther (1962), Palacios-Vargas (1981), Palacios-Vargas \& Gómez-Anaya (1993) Palacios-Vargas (2004), Cutz-Pool et al. (2007)

Palacios-Vargas \& Thibaud (2001)

Gisin (1947), Haybach (1959), Hüther (1962), Gough (1972), Dunger (1975), Fjellberg (1976, 19 \& Jordana (1986), Fjellberg (1988, 1994), Babenko (1994), Hertzberg et al. (1994), Kováč (1994 Marshall (1995), Koehler et al. (1995), Sterzyńska \& Ehrnsberger (1997), Jordana et al. (1997), Traser (1999), Babenko (2000), Shrubovych (2002), Traser (2002), Bondarenko-Borisova \& Sar Babenko (2003a, b), Thibaud (2004), Kováč et al. (2005), Sørensen et al. (2006), Traser \& Horv (2006), Arbea \& Martínez Monteagudo (2006), Moseley (2007), Hopkin (2007), Raschmanová e Prabhoo (1971)

Yue (1999)

Mills (1934), Weber (1950), Wray (1950), Wray et al. (1963), Benner \& Kannowski (1984), Fjellb 1986, 1988), Rusek (1994), Babenko (1994), Fjellberg (1994, 1998), d'Haese (1998), Babenko Thibaud (2004), Sørensen et al. (2006), Addison et al. (2006)

Thibaud (1994)

Kaprus' \& Nevo (2003)

Barra (1995)

Babenko (2002), Stebaeva (2003), Babenko (2003a, b), Thibaud (2004), Babenko $(2008,2009)$ Fjellberg (2007)

Kaprus' (1997), Skarżyński \& Smolis (2002), Thibaud (2004), Traser \& Horváth-Szováti (2006), (2006)

3 Tamura \& Zhao (1997), d'Haese \& Weiner (1998), Thibaud (2004) 
Abrahamsen, G., Hovland, J., Hågvar, S., 1980. Effects of artificial acid rain and liming on soil organisms and the decomposition of organic matter. In: Effects of acid precipitation on terrestrial ecosystems, eds. Hutchinson, T.C., Havas, M. Plenum Press, New York, pp. 341362.

Addison, J.A., Otvos, I.S., Battigelli, J.P., Conder, N., 2006. Does aerial spraying of Bacillus thuringiensis subsp. Kurstaki (Btk) pose a risk to nontarget soil microarthropods? Canadian Journal of Forest Research 36, 1610-1620.

Addison, J.A., Trofymow, J.A., Marshall, V.G., 2003. Abundance, species diversity, and community structure of Collembola in successional coastal temperate forests on Vancouver Island, Canada. Applied Soil Ecology 24, 233-246.

Agrell, I., 1963. A sociological analysis of soil Collembola. Oikos 14, 237-247.

Arbea, J.I., Jordana, R., 1985a. Efecto de una repoblación con coniferas en un robledal de Navarra sobre los colémbolos edáficos. Boletim da Sociedade Portuguesa de Entomologia 2, Suppl. 1, 277-286.

Arbea, J.I., Jordana, R., 1985b. Estudio ecológico de la colembofauna de los suelos del Macizo de Quinto Real (Pirineos Occidentales) y descripción de dos nuevas especies: Anurida flagellata n. sp. y. Onychiurus subedinensis n. sp. (Insecta, Collembola). Boletín de la Estación Central de Ecología 14, 57-80.

Arbea, J.I., Jordana, R., 1986. Estudio del género Willemia en Navarra con especial referencia a la quetotaxia dorsal de la antenna (Collembola, Hypogastruridae). In: Actas de las VIII Jornadas de la Asociacíon Española de Entomología, Sevilla, September 29-October 3, 1986. Universidad de Sevilla, Sevilla, pp. 213-222.

Arbea, J.I., Jordana, R., 1989. Colémbolos del Moncayo (Zaragoza) (Insecta: Apterygota). I. Nota biogeográfica. Turiaso 9, 571-583.

Arbea, J.I., Jordana, R., 1990. Ecología de las poblaciones de colémbolos edáficas en un prado y un pinar de la regíon submediterránea de Navarra. Mediterránea, Serie de Estudios Biológicos 12, 139-148.

Arbea, J.I., Martínez Monteagudo, A., 2006. Los colémbolos (Hexapoda, Collembola) asociados a plantas aromáticas (Labiateae) silvestres y cultivadas de la comarca valenciana de la Serranía. Boletin de la Asociacíon Española de Entomología 30, 59-71.

Ardanaz, A., Jordana, R., 1986. Estudio ecológico sobre la fauna colembológico de las peñas de Echauri, Navarra (Insecta, Collembola). I. Hayedo. In: Actas de las VIII Jornadas de la Asociacíon Española de Entomología, Sevilla, September 29-October 3, 1986. Universidad de Sevilla, Sevilla, pp. 235-243.

Arpin, P., Ponge, J.F., Dabin, B., Mori, A., 1984. Utilisation des nématodes Mononchida et des collemboles pour caractériser des phénomènes pédobiologiques. Revue d'Écologie et de Biologie du Sol 21, 243-268. 
Arpin, P., David, J.F., Guittonneau, G.G., Kilbertus, G., Ponge, J.F., Vannier, G., 1986. Influence du peuplement forestier sur la faune et la microflore du sol et des humus. I. Description des stations et étude de la faune du sol. Revue d'Écologie et de Biologie du Sol 23, 89-118.

Arpin, P., Kilbertus, G., Ponge, J.F., Vannier, G., Verdier, B., 1985. Réactions des populations animals et microbiennes du sol à la privation des apports annuels de litière: exemple d'une rendzine forestière. Bulletin d'Écologie 16, 95-115.

Auclerc, A., Ponge, J.F., Barot, S., Dubs, F., 2009. Experimental assessment of habitat preference and dispersal ability of soil springtails. Soil Biology and Biochemistry 41, 1596-1604.

Axelsson, B., Lohm, U., Lundkvist, H., Persson, T., Skoglund, J., Wirén, A., 1973. Effects of nitrogen fertilization on the abundance of soil fauna populations in a Scots pine stand. Royal College of Forestry, Stockholm, Department of Forest Ecology and Forest Soils, Research Notes 14, 118.

Axelsson, B., Lohm, U., Persson, T., 1984. Enchytraeids, lumbricids and soil arthropods in a northern deciduous woodland: a quantitative study. Horlarctic Ecology 7, 91-103.

Bååth, E., Berg, B., Lohm, U., Lundgren, B., Lundkvist, H., Rosswall, T., Söderström, B., Wirén, A., 1980. Effects of experimental acidification and liming on soil organisms and decomposition in a Scots pine forest. Pedobiologia 20, 85-100.

Babenko, A.B., 1994. Collembola in polar desert region of Devon Island, Canada, N.W.T. Entomological Review 73, 134-141.

Babenko, A.B., 2000. Collembolan assemblages of polar deserts and subarctic nival communities. Pedobiologia 44, 421-429.

Babenko, A.B., 2002. Springtails of Western Putorana Plateau (Middle Siberia): fauna and altitude differentiation of assemblages. Entomological Review 82, 901-919.

Babenko, A.B., 2003a. Landscape chorology of springtails in the Taimyr Peninsula. I. Biotopic distribution of species. Entomological Review 83, 1003-1021.

Babenko, A.B., 2003b. Landscape chorology of springtails in the Taimyr Peninsula. II. Latitudinal species differentiation. Entomological Review 83, 1194-1207.

Babenko, A.B., 2008. Springtails (Hexapoda, Collembola) in karst landscapes of the Pinega State Reserve. Entomological Review 88, 150-163.

Babenko, A.B., 2009. Are there many tundra species among Collembola of the tundra belt? In: Species and communities in extreme environments, eds. Golovatch, S.I., Makarova, O.L., Babenko, A.B., Penev, L.D. Pensoft Publishers, Sofia, pp. 113-130.

Barra, J.A., 1995. Nouveaux collemboles poduromorphes des sables littoraux (partie terrestre) de la Province du Natal (Rép. Sud Africaine) (Insecta: Collembola). Journal of African Zoology 109, 125-139. 
Barrocas, H.M., da Gama, M.M., Sousa, J.P., Ferreira, C.S., 1998. Impact of reafforestation with Eucalyptus globules Labill. On the edaphic collembolan fauna of Serra de Monchique (Algarve, Portugal). Miscellània Zoològica 21.2, 9-23.

Battigelli, J.P., Marshall, V.G., 1993. Relationships between soil fauna and soil pollutants. In: Proceedings of the Forest Ecosystem Dynamics Workshop, ed. Marshall, V. FRDA Research Report 210, 31-34.

Bellinger, P.F., 1954. Studies of soil fauna with special reference to the Collembola. Connecticut Agricultural Experiment Station, New Haven, Bulletin 583, 1-67.

Bengtsson, G., Rundgren, S., 1988. The Gusum case: a brass mill and the distribution of soil Collembola. Canadian Journal of Zoology 66, 1518-1526.

Benner, B.L., Kannowski, P.B., 1984. Collembola of Southwestern North Dakota: species composition and habitat distribution. The Prairie Naturalist 16, 79-90.

Blackith, R.E., 1974. The ecology of Collembola in Irish blanket bogs. Proceedings of the Royal Irish Academy, Section B, Biological, Geological and Chemical Science 74, 203-226.

Bödvarsson, H., 1973. Contributions to the knowledge of Swedish forest Collembola, with notes on seasonal variation and alimentary habits. Royal College of Forestry, Stockholm, Institute of Forest Zoology, Research Notes 13, 1-43.

Bolger, T., 1986. The Collembola of Ireland: a checklist and bibliography. Proceedings of the Royal Irish Academy, Section B, Biological, Geological and Chemical Science 86, 183-218.

Bondarenko-Borisova, I.V., Sandul, N.G., 2002. The fauna of springtails (Collembola) from the forest ecosystems of South-East Ukraine. Vestnik Zoologii 36, 11-21.

Bonet, F. 1945. Nuevos géneros y especies de hipogastruridos de México (Collembola). Revista de la Sociedad Mexicana de Historia Natural 6, 13-45.

Bonnet, L., Cassagnau, P., Deharveng, L., 1976. Un exemple de rupture de l'équilibre biocénotiaue par déboisement: les peuplements de collemboles édaphiques du Piau d'Engaly (HautesPyrénées). Revue d'Écologie et de Biologie du Sol 13, 337-351.

Bonnet, L., Cassagnau, P., Deharveng, L., 1979. Recherche d'une méthodologie dans l'analyse de la rupture des équilibres biocénotiques: applications aux collemboles édaphiques des Pyrénées. Revue d'Écologie et de Biologie du Sol 16, 373-401.

Broza, M., Poliakov, D., Gruia, M., Bretfeld, G., 2004. Soil collembolan communities on north and south-facing slopes of an eastern Mediterranean valley. Pedobiologia 48, 537-543.

Cassagnau, P, 1961. Écologie du sol dans les Pyrénées Centrales: les biocénoses des. collemboles. Hermann, Paris.

Cassagnau, P., Rapoport, E.H., 1962. Collemboles d'Amérique du Sud. I. Poduromorphes. In: Biologie de l'Amérique australe, Volume 1, Études sur la faune du sol, eds. Delamare- 
Deboutteville, C., Rapoport, E.H. Centre National de la Recherche Scientifique, Paris, pp. 139-184.

Cassagne, N., Bal-Serin, M.C., Gers, C., Gauquelin, T., 2004. Changes in humus properties and collembolan communities following the replanting of beech forests with spruce. Pedobiologia $48,267-276$.

Cassagne, N., Gers, C., Gauquelin, T., 2003. Relationships between Collembola, soil chemistry and humus types in forest stands (France). Biology and Fertility of Soils 37, 355-361.

Chagnon, M., Hébert, C., Paré, D., 2000a. Community structures of Collembola in sugar maple forests: relations to humus type and seasonal trends. Pedobiologia 44, 148-174.

Chagnon, M., Paré, D., Brais, S., 2001b. La biodiversité des collemboles et les débris ligneux aprèscoupe. Le Naturaliste Canadien 125, 122-125.

Chagnon, M., Paré, D., Hébert, C., 2000b. Relationships between soil chemistry, microbial biomass and the collembolan fauna of southern Québec sugar maple stands. Écoscience 7, 307-316.

Chagnon, M., Paré, D., Hébert, C., Camiré, C., 2001a. Effects of experimental liming on collembolan communities and soil microbial biomass in a southern Quebec sugar maple (Acer saccharum Marsh.) stand. Applied Soil Ecology 17, 81-90.

Chahartaghi, M., Scheu, S., Ruess, L., 2006. Sex ratio and mode of reproduction in Collembola of an oak-beech forest. Pedobiologia 50, 331-340.

Chauvat, M., Ponge, J.F., 2002. Colonization of heavy metal-polluted soils by Collembola: preliminary experiments in compartmented boxes. Applied Soil Ecology 21, 91-106.

Chauvat, M., Wolters, V., Dauber, J., 2007. Response of collembolan communities to land-use change and grassland succession. Ecography 30, 183-192.

Chauvat, M., Zaitsev, A.S., Wolters, V., 2003. Successional changes of Collembola and soil microbiota during forest rotation. Oecologia 137, 269-276.

Christiansen, K., Bellinger, P., 1980. The Collembola of North America north of the Rio Grande: a taxonomic analysis. Grinnell College, Grinnell.

Christiansen, K., Bellinger, P., 1992. Insects of Hawaii, Volume 15, Collembola. University of Hawaii Press, Honolulu.

Culik, M.P., Dos Santos Martins, D., Ventura, J.A., 2006. Collembola (Arthropoda: Hexapoda) communities in the soil of papaya orchards managed with conventional and integrated production in Espírito Santo, Brazil. Biota Neotropica 6.3 (doi:10.1590/S167606032006000300019).

Culik, M.P., Zeppelini, D.F ${ }^{\circ}$, 2003. Diversity and distribution of Collembola (Arthropoda: Hexapoda) of Brazil. Biodiversity and Conservation 12, 1119-1143. 
Cutz-Pool, L.Q., García-Gómez, A., Palacios-Vargas, J.G., 2007. Primer studio de colémbolos (Hexapoda: Collembola) de la Hoya de las Guaguas, en el estado de San Luis Potosí, México. Dugesiana 14, 47-51.

Debeljak, M., Cortet, J., Demšar, D., Krogh, P.H., Džeroski, S., 2007. Hierarchical classification of environmental factors and agricultural practices affecting soil fauna under cropping systems using Bt maize. Pedobiologia 51, 229-238.

Deharveng, L., 1996. Soil Collembola diversity, endemism, and reforestation: a case study in the Pyrenees (France). Conservation Biology 10, 74-84.

Deharveng, L., Lek, S., 1995. High diversity and community permeability: the riparian Collembola (Insecta) of a Pyrenean massif. Hydrobiologia 312, 59-74.

Dunger, W., 1975. Collembolen aus dem Börzsöny-Gebirge. Folia Historico-Naturalia Musei Matraensis 3, 11-33.

Dunger, W., Schulz, H.J., Zimdars, B., Hohberg, K., 2004. Changes in collembolan species composition in eastern Germany mine sites over fifty years of primary succession. Pedobiologia 48, 503-517.

Filser, J., 1995. The effect of green manure on the distribution of Collembola in a permanent row crop. Biology and Fertility of Soils 19, 303-308.

Filser, J., Hölscher, G., 1997. Experimental studies on the reactions of Collembola to copper contamination. Pedobiologia 41, 173-178.

Fjellberg, A., 1976. Collembola from mountains in South Norway. Norwegian Journal of Entomology 23, 127-137.

Fjellberg A., 1984. Collembola from the Colorado Front Range, U.S.A. Arctic and Alpine Research $16,193-208$.

Fjellberg, A., 1985. Arctic Collembola. I. Alaskan Collembola of the families Poduridae, Hypogastruridae, Odontellidae, Brachystomellidae and Neanuridae. Entomologica Scandinavica, Supplement 21, 1-126.

Fjellberg, A., 1986. Collembola of the Canadian high arctic: review and additional records. Canadian Journal of Zoology 64, 2386-2390.

Fjellberg, A., 1988. The collembole fauna of Troms and Finmark, North Norway. Fauna Norvegica, Series B, Norwegian Journal of Entomology 35, 5-20.

Fjellberg, A., 1991. Tibiotarsal chaetotaxy in Willemia Börner, with description of a new species from North America (Collembola: Hypogastruridae). Entomologica Scandinavica 22, 205-207.

Fjellberg, A., 1992. Collembola of the Canary Islands. I. Introduction and survey of the family Hypogastruridae. Entomologica Scandinavica 22, 437-456. 
Fjellberg, A., 1994. The Collembola of the Norwegian arctic islands. Meddelelser, Norsk Polarinsttitutt 133, 1-54.

Fjellberg, A., 1998. The Collembola of Fennoscandia and Denmark. Part I. Poduromorpha. Brill, Leiden.

Fjellberg, A., 2007. Willemia unispina sp. n. a new species of Collembola (Hypogastruridae) from West Norway. Norwegian Journal of Entomology 54, 33-36.

Fratello, B., Bertolani, R., Sabatini, M.A., Mola, L., Rassu, M.A., 1985. Effects of atrazine on soil microarthropods in experimental maize fields. Pedobiologia 28, 161-168.

da Gama, M.M., Sousa, J.P., Ferreira, C., Barrocas, H., 1997. Endemic and rare Collembola distribution in high endemism areas of South Portugal: a case study. European Journal of Soil Biology 33, 129-140.

da Gama, M.M., Sousa, J.P., Seabra, C., Barrocas, H., 1998. Analysis of collembolan communities in high endemism areas of Algarve with particular emphasis to endemic or rare species. Revista de Biologia 16, 67-86.

García-Gómez, A., Castaño-Meneses, G., Palacios-Vargas, J.G., 2009. Diversity of springtails (Hexapoda) according to an altitudinal gradient. Pesquisa Agropecuária Brasileira 44, 911916.

García-Gómez, A., Cutz-Pool, L.Q., 2008. Nueva Willemia del grupo anophthalma (Collembola: Hypogastruridae) del volcán Iztaccíhuatl, México. Acta Zoológica Mexicana, Nueva Serie 24, $1-5$.

Garnier, S. Ponge, J.F., 2004. Acid-tolerant Collembola cannot colonize metal-polluted soils at neutral pH. Applied Soil Ecology 26, 201-208.

Gerdsmeier, J., Greven, H., 1987. Zur Kenntnis der Collembolenfauna des Eggegebirges. Abhandlungen aus dem Westfälischen Museum für Naturkunde 49.4, 1-49.

Gerdsmeier, J., Greven, H., 1992. Synökologische und produktionsbiologische Untersuchungen an Collembolen aus Buchenwäldern des Eggegebirges (Westfalen): ein Beitrag zur Immissionsbelastung von Wäldern. Abhandlungen aus dem Westfälischen Museum für Naturkunde 54.1, 1-76.

Gers, C., Deharveng, L., 1985. Collemboles de l'Oukaimeden (Haut-Atlas de Marrakech, Maroc). Bulletin de la Société d'Histoire Naturelle de Toulouse 121, 51-61.

Gers, C., de Izarra, D.C., 1983. Rupture de l'équilibre biocénotique des populations de collemboles à la station de ski de Calmazeille-Formiguères (Pyrénées Orientales). Bulletin de la Société d'Histoire Naturelle de Toulouse 119, 63-69.

Gillet, S., Ponge, J.F., 2004. Are acid-tolerant Collembola able to colonize metal-polluted soil? Applied Soil Ecology 26, 219-231. 
Gillet, S., Ponge, J.F., 2005. Species assemblages and diets of Collembola in the organic matter accumulated over an old tar deposit. European Journal of Soil Biology 41, 39-44.

Gisin, H., 1943. Ökologie und Lebengemeinschaften der Collembolen im schweizerischen Exkursionsgebiet Basels. Revue Suisse de Zoologie 50, 131-224.

Gisin, H., 1947. Sur les insectes aptérygotes du Parc National Suisse: espèces et groupements euédaphiques. In: Résultats des recherches scientifiques entreprises au Parc National Suisse, Volume 2. Sauerlander, Aarau, pp. 77-91.

Gisin, H., 1960. Collembolenfauna Europas. Muséum d'Histoire Naturelle, Genève.

Gómez-Anaya, J.A., Palacios-Vargas, J.G., 2004. Structure and competition of litter and soil Poduromorpha assemblages (Hexapoda Entognatha: Collembola) from a tropical dry forest in western Mexico. Folia Entomologica Mexicana 43, 215-225.

Gough, H.J., 1972. A note on the British species of Willemia (Collembola: Hypogastruridae) with a key to the species. Entomologist's Monthly Magazine 108, 80-83.

Gruia, M., 2003. Collembola from Romanian caves. Travaux du Muséum National d'Histoire Naturelle "Grigore Antipa" 45, 139-158.

d'Haese, C., 1998. Willemia anophthalma-group (Collembola: Hypogastruridae): systematic, new species, distribution and habitats. European Journal of Entomology 95, 581-592.

d'Haese, C., Weiner, W.M., 1998. A review of Willemia buddenbrocki-group (Collembola, Poduromorpha, Hypogastruridae) with cladistic analysis. Journal of Natural History 32, 969986.

Hågvar, S., 1982. Collembola in Norwegian coniferous forest soils. I. Relations to plant communities and soil fertility. Pedobiologia 24, 255-296.

Hågvar, S., 1983. Collembola in Norwegian coniferous forest soils. II. Vertical distribution. Pedobiologia 25, 383-401.

Hågvar, S., 1984. Effects of liming and artificial acid rain on Collembola and Protura in coniferous forest. Pedobiologia 27, 341-354.

Hågvar, S., 1984. Ecological studies of microarthropods in forest soils, with emphasis on relations to soil acidity. Norwegian Forest Research Institute, Ås.

Hågvar, S., 1987. Effects of artificial acid precipitation and liming on forest microarthropods. In: Soil fauna and soil fertility, ed. Striganova, B.R. Nauka, Moscow, pp. 661-668.

Hågvar, S., 1994. Log-normal distribution of dominance as an indicator of stressed soil microarthropod communities. Acta Zoologica Fennica 195, 71-80.

Hågvar, S., Abrahamsen, G., 1984. Collembola in Norwegian coniferous forest soils. III. Relations to soil chemistry. Pedobiologia 27, 331-339. 
Hågvar, S., Abrahamsen, G., 1990. Microarthropoda and Enchytraeidae (Oligochaeta) in naturally lead-contaminated soil: a gradient study. Environmental Entomology 19, 1263-1277.

Hågvar, S., Kjøndal, B.R., 1981a. Succession, diversity and feeding habits of microarthropods in decomposing borch leaves. Pedobiologia 22, 385-408.

Hågvar, S., Kjøndal, B.R., 1981b. Effects of artificial acid rain on the microarthropod fauna in decomposing birch leaves. Pedobiologia 22, 409-422.

Haimi, J., Siira-Pietikäinen, A., 1996. Decomposer animal communities in forest soil along heavy metal pollution gradient. Fresenius' Journal of Analytical Chemistry 354, 672-675.

Hale, W.G., 1966. A population study of moorland Collembola. Pedobiologia 6, 65-99.

Handschin, E., 1924. Die Collembolenfauna des schweizerischen Nationalparkes. Denkschriften der Schweizerischen Naturforschenden Gesellschaft 60, 89-174.

Haybach, G., 1959. Über die Collembolenfauna verschiedener Waldböden. Verhandlungen der Zoologisch-Botanischen Gesellschaft in Wien 98/99, 31-51.

Hertzberg, K., Leinaas, H.P., Ims, R.A., 1994. Patterns of abundance and demography: Collembola in a habitat patch gradient. Ecography 17, 349-359.

Hopkin, S.P., 2007. A key to the Collembola (springtails) of Britain and Ireland. Field Studies Council, Shrewsbury.

Huhta, V., Hyvönen, Kaasalainen, P., Koskenniemi, A., Muona, J., Mäkelä, I., Sulander, M., Vilkamaa, P., 1986. Soil fauna of Finnish coniferous forests. Annales Zoologici Fennici 23, 345-360.

Huhta, V., Hyvönen, R., Koskenniemi, A., Vilkamaa, P., 1983. Role of pH in the effects of fertilization on Nematoda, Oligochaeta and microarthropods. In: New trends in soil biology, eds. Lebrun, P;, André, H.M., de Medts, A., Grégoire-Wibo, C., Wauthy, G. Université Catholique de Louvain, Louvain-la-Neuve, pp. 61-73.

Huhta, V., Ikonen, E., Vilkamaa, P., 1979. Succession of invertebrate populations in artificial soil made of sewage sludge and crushed bark. Annales Zoologici Fennici 16, 223-270.

Huhta, V., Ojala, R., 2006. Collembolan communities in deciduous forests of different origin in Finland. Applied Soil Ecology 31, 83-90.

Hüther, W., 1959. Willemia buddenbrocki n.sp., und zur Chaetotaxie von W. Persimilis Bonet 1945 (Collembola). Senckenbergiana Biologica 40, 173-177.

Hüther, W., 1962. Beitrag zur Gattung Willemia Börner. Beitrage zur Entomologie 12, 511-526.

Hutson, B.R., 1980a. Colonization of industrial reclamation sites by Acari, Collembola and other invertebrates. Journal of Applied Ecology 17, 255-275.

Hutson, B.R., 1980b. The influence on soil development of the invertebrate fauna colonizing industrial reclamation sites. Journal of Applied Ecology 17, 277-286. 
de Izarra, D.C., 1981. Las prácticas agrícolas y sus efectos sobre la fauna de los colémbolos de un suelo de la región semiárida. Anales de Edafología y Agrobiología 40, 1193-1203.

Jahn, E., 1972. Ausgelesene Bodentier-Arten aus Böden der Brandfläche an den Südhängen der Nockspitze (Saile bei Innsbruck) in den Jahren 1968/69. Berichte des NaturwissenschaftlichMedizinischen Vereins in Innsbruck 59, 67-72.

Jínova, K., Rusek, J., 2007. Litter attractivity for soil Collembola in litterbag decomposition experiment. In: Contributions to soil zoology in Central Europe II, eds. Tajovský, K., Schlaghamerský, K., Pižl, V. Institute of Soil Biology, Biology Centre, Academy of Sciences of the Czech Republic, České Budějovice, pp. 69-74.

Jordana, R., Arbea, J.I., Simón, C., Luciáñez, M.J., 1997. Fauna Iberica, Volumen 8, Collembola Poduromorpha. Museo Nacional de Ciencias Naturales, Madrid.

Kaczmarek, M., 1975a. An analysis of Collembola communities in different pine forest communities. Ekologia Polska 23, 265-293.

Kaczmarek, M., 1975b. Infleunce of humidity and specific interactions on collembolan populations in a pine forest. In: Progress in soil zoology, ed. Vaněk, J. Academia, Prague, pp. 333-340.

Kannowski, P.B., 1984. Collembola of Southwestern North Dakota: species composition and habitat distribution. The Prairie Naturalist 16, 79-90.

Kaprus', I.J., 1997. New species of the genus Willemia Börner, 1901 (Collembola) from a cave in the Ukraine. Acta Zoologica Cracoviensia 40, 37-39.

Kaprus', I.J., Nevo, E., 2003. New species of Collembola (Entognatha) from Israel. Vestnik Zoologii $37,65-70$.

Koehler, H., Munderloh, E., Hofmann, S., 1995. Soil microarthropods (Acari, Collembola) from beach and dune: characteristics and ecosystem context. Journal of Coastal Conservation 1, 77-86.

Koolhaas, J.E., Van Gestel, C.A.M., Römbke, J., Soares, A.M.V.M., Jones, S.E., 2004. Ring-testing and field-validation of a Terrestrial Model Ecosystem (TME), an instrument for testing potentially harmful substances: effects of carbendazim on soil microarthropod communities. Ecotoxicology 13, 75-88.

Kopeszki, H., Meyer, E., 1994. Artenzusammensetzung und Abundanz von Collembolen in Waldböden Vorarlsberg (Österreich). Berichte des Naturwissenschaftlich-Medizinen Vereins in Innsbruck 81, 151-166.

Kopeszki, H., Meyer, E., 1996. Artenzusammensetzung und Abundanz von Collembolen in Waldböden der provinzen Bozen und Trient (Italien). Berichte des NaturwissenschaftlichMedizinen Vereins in Innsbruck 83, 221-237.

Kopeszki, H., Trockner, V., 1994. Auswirkungen des Skibetrielos auf die Collembolenfauna einer alpine Wiese im Grödental (Südtirol). Zoologischer Anzeiger 233, 221-239. 
Kováč, L., 1994. Effects of soil type on collembolan communities in agroecosystems. Acta Zoologica Fennica 195, 89-93.

Kováč, L., Kostúrova, N., Miklisová, D., 2005. Comparison of collembolan assemblages (Hexapoda, Collembola) of thermophilous oak woods and Pinus nigra plantations in the Slovak karst (Slovakia). Pedobiologia 49, 29-40.

Kováč, L., Miklisová, D., 1995. Collembolan communities in winter wheat-clover cropping system on two different soil types. Polskie Pismo Entomologiczne 64, 365-381.

Kuznetsova, N.A., 1987. Correlation pleiads of Collembola in coniferous forests. In: Soil fauna and fertility, ed. Striganova, B.R. Nauka, Moscow, pp. 680-683.

Kuznetsova, N.A., 2002. Classification of collembolan communities in the East-European taiga. Pedobiologia 46, 373-384.

Kuznetsova, N.A., 2006. Long-term dynamics of Collembola in two contrasting ecosystems. Pedobiologia 50, 157-164.

Kuznetsova, N.A., 2007. Long-term dynamics of collembolan populations in forest and meadow ecosystems. Entomological review 87, 11-24.

Lauga-Reyrel, F., Lauga, J., 1995. Collembola of cold Pyrenean habitats. European Journal of Soil Biology 31, 217-229.

Lek-Ang, S., Deharveng, L., 2002. Seasonal variations of Collembola (Hexapoda) assemblages in damp riparian habitats. Archiv für Hydrobiologie 153, 635-655.

Lienhard, C., 1980. Zur Kenntnis der Collembolen eines alpinen Caricetum firmae im Schweizerischen Nationalpark. Pedobiologia 20, 369-386.

Lindberg, N., Bengtsson, J., 2005. Population responses of oribatid mites and collembolans after drought. Applied Soil Ecology 28, 163-174.

Lindberg, N., Persson, T., 2004. Effects of long-term nutrient fertilisation and irrigation on the microarthropod community in a boreal Norway spruce stand. Forest Ecology and Management $188,125-135$.

Liiri, M., Haimi, J., Setälä, H., 2002. Community composition of soil microarthropods of acid forest sites as affected by wood ash application. Pedobiologia 46, 108-124.

Lohm, U., Lundkvist, H., Persson, T., Wirén, A., 1977. Effects of nitrogen fertilization on the abundance of enchytraeids and microarthropods in Scots pine forests. Studia Forestalia Suecica 140, 1-23.

Loksa, I., 1978. Mikrohabitate und ihre Bedeutung für die Verteilung der Collembolengemeinschaften in einem Hainbuchen-Eichenbestand. Opuscula Zoologica Instituti Zoosystematici et Oecologici Universitatis Budapestiensis 15, 93-117. 
Lopes, C.M., da Gama, M.M., 1994. The effect of fire on collembolan populations of Mata da Margaraça (Portugal). European Journal of Soil Biology 30, 133-141.

Loranger, G., Bandyopadhyaya, I., Razaka, B., Ponge, J.F., 2001. Does soil acidity explain altitudinal sequences in collembolan commuunities? Soil Biology and Biochemistry 33, 381-393.

Luciáñez Sánchez, M.J., Simón Benito, J.C., 1988. Estudio colembológico de un robledal y un pinar en la vertiente sur de la sierra de Gredos. Eos 64, 57-87.

Marlier, G.J., 1942. Notes sur les collemboles. I. La faune des collemboles de la Belgique. Bulletin du Musée Royal d'Histoire Naturelle de Belgique 18, 1-11.

Mateos, E., 1988. Ecología de los colémbolos (Collembola, Insecta) edáficos del encinar montano del Montseny (Barcelona). Miscellania Zoologica 12, 97-107.

Mateos, E., Selga, D., 1991. Efecto de los incendios forestales sobre las poblaciones de colémbolos edáficos en bosque mediterráneo. Revue d'Écologie et de Biologie du Sol 28, 19-30.

Materna, J., 2004. Does forest type and vegetation patchiness influence horizontal distribution of soil Collembola in two neighbouring forest sites? Pedobiologia 48, 339-347.

McClure, H.E., Lim, B.L., Winn, S.E., 1967. Fauna of the Dark Cave, Batu Caves, Kuala Lumpur, Malaysia. Pacific Insects 9, 399-428.

Melecis, V., 1987. Springtails (Collembola) as bioindicators of soil pollution. In: Soil fauna and soil fertility, ed. Striganova, B.R. Nauka, Moscow, pp. 684-686.

Mills, H.B., 1934. A monograph of the Collembola of Iowa. Collegiate Press, Ames.

Mordkovich, V.G., Berezina, O.G., Lyubechanskii (I.I.), Andrievskii (V.S.), Marchenko, I.I., 2008. Soil Arthropoda of post-fire successions in northern taiga of West Siberia. Contemporary Problems of Ecology 1, 96-103.

Moseley, M., 2007. Acadian biospeleology: composition and ecology of cave fauna of Nova Scotia and southern New Brunswick, Canada. International Journal of Speleology 36, 1-21.

Najt, J., Thibaud, J.M., Weiner, W.M., 1990. Collemboles (Insecta) poduromorphes de Guyane française. Bulletin du Muséum National d'Histoire Naturelle de Paris, Quatrième Série, Section A, Zoologie, Biologie et Écologie Animales 12, 95-121.

Nosek, J., 1967. The investigation on the Apterygotan fauna of the Low Tatras. Acta Universitatis Carolinae, Biologica 5, 349-528.

Ojala, R., Huhta, V., 2001. Dispersal of microarthropods in forest soil. Pedobiologia 45, 443-450.

Otrysko, B., Pagé, F., 2001. Effets d'apports de bois raméaux fragmentés (BRF) et d'un compost combines à des rotations avec engrais verts sur les rendements en pomme de terre et l'incidence de la gale. Agrosol 12, 108-117.

Palacios-Vargas, J.G., 1981. Collembola asociados a Tillandsia (Bromeliaceae) en el Derrame Lávico del Chichinautzin, Morelas, México. The Southwestern Entomologist 6, 87-98. 
Palacios-Vargas, J.G., 1987. Nueva especie de Willemia y nuevo registro de W. buddenbrocki brevispina para Nicaragua (Collembola: Hypogastruridae). Folia Entomológica Mexicana 73, $5-9$.

Palacios-Vargas, J.G., 1990. Nuevos Collembola del estado de Chihuahua, México. Folia Entomologica Mexicana 79, 5-32.

Palacios-Vargas, J.G., Gómez-Anaya, J.A., 1993. Los Collembola (Hexapoda: Apterygota) de Chamela, Jalisco, México (distribución ecológica y claves). Folia Entomologica Mexicana 89, $1-34$.

Palacios-Vargas, J.G., Thibaud, J.M., 2001. Three new species of Mexican littoral Collembola of genera Willemia, Cryptopygus and Isotogastrura (Hypogastruridae, Isotomidae, Isotogastruridae). Revue Française d'Entomologie, Nouvelle Série 23, 161-168.

Palacios-Vargas, J.G., Vázquez, M.M., 1988. Three new species of littoral Collembola (Hypogastruridae) from Baja California Sur, Mexico. Journal of the Kansas Entomological Society 61, 433-440.

Persson, T., Lohm, U., 1977. Energetical significance of the annelids and arthropods in a Swedish grassland soil. Ecological Bulletins 23, 1-211.

Petersen, H., 1965. The Collembola of the Hansted Reserve, Thy, North Jutland. Entomologiske Meddelelser 30, 313-395.

Petersen, H., 1980. Population dynamic and metabolic characterization of Collembola species in a beech forest ecosystem. In: Soil biology as related to land use practices, ed. Dindal, D.L. Office of Pesticide and Toxic Substances, Environmental protection Agency, Washington, pp. 806-833.

Petersen, H., 1995. Temporal and spatial dynamics of soil Collembola during secondary succession in Danish heathland. Acta Zoologica Fennica 196, 190-194.

Petersen, H., Jucevica, E., Gjelstrup, P., 2004. Long-term changes in collembolan communities in grazed and non-grazed abandoned arable fields in Denmark. Pedobiologia 48, 559-573.

Pflug, A., Wolters, V., 2002. Collembola communities along a European transect. European Journal of Soil Biology 38, 301-304.

Pichard, S., Massoud, Z., Elkaim, B., 1989. Écologie des peuplements de collemboles de quelques mares et de leurs abords en région parisienne. Revue d'Écologie et de Biologie du Sol 26, 451-472.

Poinsot-Balaguer, N., Tabone, E., 1986. Étude d'un écosystème forestier méditerranéen. II. Les collemboles d'une forêt mixte (chênes verts, Quercus ilex L. - chênes blancs, Quercus pubescens W.) de la région provençale. Bulletin d'Écologie 17, 87-95.

Ponge, J.F., 1980. Les biocénoses des collemboles de la Forêt de Sénart. In: Actualités d'écologie forestière, ed. Pesson, P. Gauthier-Villars, Paris, pp. 151-176. 
Ponge, J.F., 1983. Les collemboles, indicateurs du type d'humus en milieu forestier: résultats obtenus au sud de Paris. Acta Oecologica, Oecologia Generalis 4, 359-374.

Ponge, J.F., 1993. Biocenoses of Collembola in atlantic grass-woodland ecosystems. Pedobiologia 37, 223-244.

Ponge, J.F., 2000a. Acidophilic Collembola: living fossils? Contributions from the Biological Laboratory, Kyoto University 29, 65-74.

Ponge, J.F., 2000b. Vertical distribution of Collembola (Hexapoda) and their food resources in organic horizons of beech forests. Biology and Fertility of Soils 32, 508-522.

Ponge, J.F., Bandyopdhyaya, I., Marchetti, V., 2002. Interaction between humus form and herbicide toxicity to Collembola (Hexapoda). Applied Soil Ecology 20, 239-253.

Ponge, J.F., Dubs, F., Gillet, S., Sousa, J.P., Lavelle, P., 2006. Decreased biodiversity in soil springtail communities: the importance of dispersal and landuse history in heterogeneous landscapes. Soil Biology and Biochemistry 38, 1158-1161.

Ponge, J.F., Gillet, S., Dubs, F., Fédoroff, E., Haese, L., Sousa, J.P., Lavelle, P., 2003. Collembolan communities as bioindicators of land use intensification. Soil Biology and Biochemistry 35, 813-826.

Ponge, J.F., Prat, B., 1982. Les collemboles, indicateurs du mode d'humification dans les peuplements résineux, feuillus et mélangés: résultats obtenus en Forêt d'Orléans. Revue d'Écologie et de Biologie du Sol 19, 237-250.

Ponge, J.F., Vannier, G., Arpin, P., David, J.F., 1986. Caractérisation des humus et des litières par la faune du sol: intérêt sylvicole. Revue Forestière Française 38, 509-516.

Poursin, J.M., Ponge, J.F., 1984. Étude des peuplements de microarthropodes (insectes collemboles et acariens oribates) dans trois humus forestiers acides de la Forêt d'Orléans (Loiret, France). Pedobiologia 26, 403-414.

Pozo, J., 1986. Ecological factors affecting Collembola populations: ordination of communities. Revue d’Écologie et de Biologie du Sol 23, 299-311.

Pozo, J., Selga, D., Simon, J.C., 1986. Studies on the collembolan populations of several plant communities of the basque Country (Spain). Revue d'Écologie et de Biologie du Sol 23, 215 232.

Prabhoo, N.R., 1971. Soil and litter Collembola of South India. I. Arthropleona. Oriental Insects 5, 146.

Rapoport, E.H., 1962. Colémbolos de Bahía Blanca. Publicaciones del Instituto de Edafología e Hidrología 2, 3-24.

Rapoport, E.H., Rubio, I., 1963. Fauna colembologica de Chile. Investigaciones Zoológicas Chilenas 9, 95-124. 
Raschmanová, N., Kováč, L., Miklisová, D., 2008. The effects of mesoclimate on Collembola diversity in the Zádiel Valley, Slovak Karst (Slovakia). European Journal of Soil Biology 44, 463-472.

Rebecchi, L., Sabatini, M.A., Cappi, C., Grazioso, P., Vicari, A., Dinelli, G., Bertolani, R., 2000. Effects of a sulfonylurea herbicide on soil microarthropods. Biology and Fertility of Soils 30, 312-317.

Rusek, J., 1968. Die Apterygotengemeinschaft der Acereto-Fraxinetum-Waldassoziation des Mährischen Karstes. Acta Societatis Zoologiae Bohemoslovacae 32, 237-261.

Rusek, J., 1990. Collembola and other microarthropods. In: Succession in abandoned fields: studies in Central Bohemia, Czechoslovakia, eds. Osbornová, J., Kovářová, M., Lepš, J., Prach, K. Geobotany 15, 56-58.

Rusek, J., 1994. Succession of Collembola and some ecosystem components on a pingo in the Mackenzie River Delta, N.W.T., Canada. Acta Zoologica Fennica 195, 119-123.

Rusek, J., 1996. Global change impact on soil fauna and ecosystems. In: Climate variability and climate change vulnerability and adaptation, ed. Nemešová, I. Czech Academy of Sciences, Institute of Atmospheric Physics, Prague, pp. 163-170.

Rusek, J., Marshall, V.G., 1995. Long-term changes of collembolan communities in forest soils. Polskie Pismo Entomologiczne 64, 159-171.

Ryan, J., 1977. Invertebrates of Truelove lowland. In: Truelove lowland, Devon Island, Canada: a high arctic ecosystem, ed. Bliss, L.C. University of Alberta Press, Edmonton, pp. 699-703.

Sabatini, M.A., Rebecchi, L., Cappi, C., Bertolani, R., Fratello, B., 1997. Long-term effects of three different continuous tillage practices on Collembola populations. Pedobiologia 41, 185-193.

Salamon, J.A., Alphei, J., 2009. The Collembola community of a Central European forest: influence of tree species composition. European Journal of Soil Biology 45, 199-206.

Salamon, J.A., Scheu, S., Schaefer, M., 2008. The Collembola community of pure and mixed stands of beech (Fagus sylvatica) and spruce (Picea abies) of different age. Pedobiologia 51, 385-396.

Salminen, J., Haimi, J., Sironen, A., Ahtiainen, J., 1995. Effects of pentachlorophenol and biotic interactions on soil fauna and decomposition in humus soil. Ecotoxicology and Environmental Safety $31,250-257$.

Shaw, P.J.A., Usher, M.B., 1996. Edaphic Collembola of lodgepole pine Pinus contorta plantations in Cumbria, UK. European Journal of Soil Biology 32, 89-97.

Shrubovych, J., 2002. The fauna of springtails (Collembola) in Lviv. Vestnik Zoologii 36, 63-67.

Siira-Pietikäinen, A., Pietikäinen, J., Fritze, H., Haimi, J., 2001. Short-term responses of soil decomposer communities to forest management: clear felling versus alternative forest harvesting methods. Canadian Journal of Forest Research 31, 88-99. 
Simón Benito, J.C., Pozo Martínez, J., 1988. Colémbolos de Cantabria. Eos 64, 203-215.

Skarżyński, D., Smolis, A., 2002. Notes on Willemia virae Kaprus' and Anurida carpatica Babenko, two springtails new for the Polish fauna, with remarks on other Collembola collected in caves of the Beskìd Nìski Mountains (Polish Carpathians). Polskie Pismo Entomologiczne 71, 301306.

Sławska, M., 2000. Collembola communities in Sphagnum basin bogs and their importance to biodiversity of pine forest. Pedobiologia 44, 413-420.

Sławska, M., Sławski, M., 2009. Springtails (Collembola, Hexapoda) in bogs of Poland. Warsaw University of Life Sciences Press, Warsaw.

Sleptzova, E.V., Reznikova, Z.I., 2006. Formation of springtail (Collembola) communities during colonization of ant-hills. Entomological Review 86, 373-382.

Sørensen, L.I., Holmstrup, M., Maraldo, K., Christensen, S., Christensen, B., 2006. Soil fauna communities and microbial respiration in High Arctic tundra soils at Zackenberg, Northeast Greenland. Polar Biology 29, 189-195.

Stebaeva, S., 2003. Collembolan communities of the Ubsu-Nur Basin and adjacent mountains (Russia, Tuva). Pedobiologia 47, 341-356.

Stebaeva, S.K., 1967. Pedobiologische Experimente mit ausgetauchten Bodenblöcken im südöstlichen Altai-Gebirge und der Severnaja Baraba. Pedobiologia 7, 172-191.

Sterzyńska, M., 1989. Collembola from urban areas (Warsaw, Poland). In: Third International Seminar on Apterygota, Siena, August 21-26, 1989, ed. Dallai; R. University of Siena, Siena, pp. 347354.

Sterzyńska, M., 1990. Communities of Collembola in natural and transformed soils of the linden-oakhornbeam sites of the Mazovian lowland. Fragmenta Faunistica 34, 165-262.

Sterzyńska, M., Bolger, T., 2004. Collembola of North Bull Island: new records for the Irish coast. Fragmenta Faunistica 47, 47-50.

Sterzyńska, M., Ehrnsberger, R., 1997. Marine algae wrack Collembola of European coasts. Abhandlungen und Berichte des Naturkundemuseums Görlitz 69, 165-178.

Syrek, D., Weiner, W.M., Wojtylak, M., Olszowska, G., Kwapis, Z., 2006. Species abundance distribution of collembolan communities in forest soils polluted with heavy metals. Applied Soil Ecology 31, 239-250.

Szeptycki, A., 1967. Fauna of the springtails (Collembola) of the Ojców National Park in Poland. Acta Zoologica Cracoviensia 12, 219-280.

Tamura, H., Zhao, L., 1997. A new species of the genus Willemia (Collembola: Hypogastruridae) from Xishuangbanna, Southwest China. Edaphologia 58, 41-44. 
Tanaka, S., Kitazawa, Y., 1982. Collembolan communities on the campus of UOEH and in an adjacent natural forest. Journal of the University of Occupational and Environmental Health 4, 313325 .

Therrien, F., Chagnon, M., Hébert, C., 1999. Biodiversity of Collembola in sugar maple (Aceraceae) forests. The Canadian Entomologist 131, 613-628.

Thibaud, J.M., 1993. Les collemboles des Petites Antilles. VI. Interstitiels terrestres et marins. Revue Française d'Entomologie, Nouvelle Série 15, 69-80.

Thibaud, J.M., 1994. Les collemboles interstitiels terrestres de l'île de Cuba, avec la description de deux espèces nouvelles. Revue Française d'Entomologie, Nouvelle Série 16, 93-98.

Thibaud, J.M., 2002. Contribution à la connaissance des collemboles interstitiels des sables littoraux du Vietnam. Revue Française d'Entomologie, Nouvelle Série 24, 201-209.

Thibaud, J.M., 2004. Synopses on Palaearctic Collembola, Volume 4, Hypogastruridae. Staatliches Museum für Naturkunde, Görlitz.

Thibaud, J.M., 2008. Les collemboles des sables littoraux de Madagascar. Annales de la Société Entomologique de France, Nouvelle Série 44, 503-519.

Thibaud, J.M., 2009a. Les collemboles (Collembola) interstitiels des sables littoraux de l'île d'Espiritu santo (Vanuatu). Zoosystema 31, 499-505.

Thibaud, J.M., 2009b. Contribution à la connaissance des collemboles interstitiels des sables littoraux du Vietnam (suite). Revue Française d'Entomologie, Nouvelle Série 31, 33-36.

Thibaud, J.M., Massoud, Z., 1988. Recherche sur la faune interstitielle aérienne des sables fins: les collemboles. II. Désert de Namibie. Annales de la Société Entomologique de France, Nouvelle Série 24, 211-214.

Thibaud, J.M., Lee, B.H., 1994. Three new species of interstitial Collembola (Insecta) from sand dunes of South Korea. Korean Journal of Systematic Zoology 10, 39-46.

Thibaud, J.M., Palacios-Vargas, J.G., 1999. Brazilian Collembola from littoral sand with description of Austrogastrura gen.n. and Isotomodes carioca sp.n. (Hypogastruridae, Isotomidae). Revue Française d'Entomologie, Nouvelle Série 21, 25-31.

Traser, G., 1999. Springtails of the Aggtelek National Park (Hexapoda: Collembola). In: The fauna of the Aggtelek National Park, ed. Mahunka, S. Hungarian Natural History Museum, Budapest, pp. 49-59.

Traser, G., 2002. The Collembola of the Fertö-Hanság National Park. In: The fauna of the FertöHanság National Park. Hungarian Natural History Museum, Budapest, pp. 259-270.

Traser, G., Horváth-Szováti, E., 2006. Land-use intensity and diversity parameters: Collembola (Insecta) communities in Csévharaszt (Hungary). In: Biotic damage in forests, eds. Csóka, G., Hirka, A., Koltay, A. Hungarian Forest Research Institute, Matrafüred, pp. 329-339. 
Traser, G., Szücs, P., Winkler, D., 2006. Collembola diversity of moss habitats in the Sopron region, NW-Hungary. Acta Silvatica et Lignaria Hungarica 2, 69-80.

Usher, M.B., 1970. Seasonal and vertical dsitribution of a population of soil arthropods: Collembola. Pedobiologia 10, 224-236.

Usher, M.B., 1976. Aggregation responses of soil arthropods in relation to the soil environment. In: The role of terrestrial and aquatic organisms in decomposition processes, eds. Anderson, J.M., Macfadyen, A. Blackwell, Oxford, pp. 61-94.

Vilkamaa, P., Huhta, V., 1986. Effects of fertilization and $\mathrm{pH}$ on communities of Collembola in pine forest soil. Annales Zoologici Fennici 23, 167-174.

Weber, N.A., 1950. A survey of the insects and related arthropods of arctic Alaska. Part I. Transactions of the American Entomological Society 76, 147-206.

Weiner, W.M., 1986. North Korean Collembola. IX. The genus Willemia Börner, 1901. Acta Zoologica Cracoviensia 29, 331-338.

Weiner, W.M., 1991. Collemboles Poduromorphes de Nouvelle-Calédonie: Willemia neocaledonica n.sp. (Hypogastruridae). Bulletin de la Société Entomologique de France 96, 93-95.

Wray, D.L., 1950. Some new Collembola from Utah and Idaho. Bulletin of the Brooklyn Entomological Society 45, 91-95.

Wray, D.L., Copeland, T.P., Davis, R.B., 1963. Collembola of the Great Smoky Mountains. Journal of the Tennessee Academy of Science 38, 85-86.

Yosii, R., 1959. Studies on the collembolan fauna of Malay and Singapora, with special reference to the genera: Lobella, Lepidocyrtus and Callyntrura. Contributions from the Biological Laboratory, Kyoto University 10, 1-65.

Yue, Q.Y., 1999. A new species of Willemia and the first record of Oncopodura from China (Insecta: Collembola). Acta Zootaxonomica Sinica 24, 295-299.

Zerling, L., 1990. Zur Sukzession von Kleinarthropoden, insbesondere Collembolen, im Bodenbildungsprozess auf einer landwirthschaftlich genutzen Braunkohlenkippe bei Leipzig. Pedobiologia 34, 315-335. 
2592

2593

2594

2595

2596

2597

2598

2599

2600

2601

2602

2603

2604

2605

2606

2607

2608

2609

2610

2611

Appendix S2c - Exploration of bias due to differences between species in numbers of records in the literature.

Methods: Because species differed in the number of records from which harshness-breadth was estimated (see above Appendix S2b, column 2), we also verified whether the number of records was 'phylogenetically conserved'. For this, we also used the root-skewness test with Euclidean distances among species. This test aims to highlight whether our results were biased by differences among species in the amount of knowledge on their environmental distribution. This approach is conservative: the intensive study of a species may increase the number of records in harsh environments (bias), but a species' use of harsh environments may also increase the chance of being observed in many of the environments studied (non-bias).

Results: There was no phylogenetic structure in the number of literature records (rootskewness test P-value $=0.326$ ) even after log-transformation (root-skewness test P-value $=$ 0.291) indicating that the analyses done in the main text on the link between phylogeny and properties of species do not depend on the extent to which these species were studied in the literature.

(1)


2612

2613

2614

2615

2616

2617

2618

2619

2620

2621

2622

2623

2624

2625

2626

2627

2628

2629

2630

2631

2632

2633

2634

2635

2636

\section{Appendix S2d: Salinity and tolerance to harshness.}

We showed that in the genus Willemia tolerance to salinity (use of haline habitats) was negatively correlated to other types of harshness and that 'haline' species exhibited on average a higher clade rank than species tolerant of other harshness factors such as drought, frost, acidity, waterlogging (anaerobiosis) or heavy metals. In the absence of ecophysiological studies on the genus Willemia, which is probably explained by the small size of these animals and their concealed way of life (d'Haese, 2000), only putative arguments can be given for rejecting salinity as a harshness factor to which Willemia should adapt for life on the seashore. A strong attraction to sodium (compared to potassium) has been shown to occur in Heteromurus nitidus, another soil-dwelling springtail species (Salmon et al., 2002). Thibaud (2007), on the base of biogeographic arguments, postulated that transport by sea currents could be responsible for the occurrence of the same Willemia species on remote seashores, whether insular or continental. Witteveen et al. (1987) showed that the ionic concentration of the haemolymph of inland Collembola equilibrated rapidly with sea water when transferred to seashore conditions. It could be suggested that permanent contact with dilute saline solutions (seashores, but not dry saline environments) needs no special adaptation in basal Hexapoda, contrary to fully terrestrial insects (higher insects), for which potassium is an essential element which replaces sodium (Wigglesworth, 1965). The ancestry of life in sea water versus freshwater has been shown to be the rule in aquatic invertebrates (Lee \& Bell, 1999). The separation we performed between tolerance to drought and to salinity, based on ecophysiological and biocenotic grounds (Hartmut et al., 1995; Thibaud, 2007), and supported by studies on other animal groups (GomezMestre \& Tejedo, 2005), might explain why psammophily (life in sand), which confounds both adaptation to drought and to salinity, exhibits a high degree of reversal along phylogenetic trees of the genus Willemia (d'Haese, 2000).

\section{REFERENCES}


Ghilarov, M.S. (1956) Soil as the environment of the invertebrate transition from the aquatic to the terrestrial life. Sixième Congrès International de la Science du Sol, Paris, 1956, Volume C, Commission III et Colloque du Riz, pp. 307-313. Laboureur, Paris.

d'Haese, C. (2000) Is psammophily an evolutionary dead end? A phylogenetic test in the genus Willemia (Collembola: Hypogastruridae). Cladistics, 16, 255-273.

Hartmut, K., Munderloh, E. \& Hofmann, S. (1995) Soil microarthropods (Acari, Collembola) from beach and dune: characteristics and ecosystem context. Journal of Coastal Conservation, $\mathbf{1}$, $77-86$.

Lee, C.E. \& Bell, M.A. (1999) Causes and consequences of recent freshwater invasions by saltwater animals. Trends in Ecology and Evolution, 14, 284-288.

Retallack, G. \& Dilcher, D.L. (1981) A coastal hypothesis for the dispersal and rise to dominance of flowering plants. Paleobotany, paleoecology and evolution, Volume 2 (ed. by K.J. Niklas), pp. 27-77. Praeger, New York.

Salmon, S., Ponge, J.F. \& Van Straalen, N.M. (2002) Ionic identity of pore water influences pH preference in Collembola. Soil Biology and Biochemistry, 34, 1663-1667.

Thibaud, J.M. (2007) Recent advances and synthesis in biodiversity and biogeography or arenicolous Collembola. Annales de la Société Entomologique de France, 43, 181-185.

Vannier, G. (1987) The porosphere as an ecological medium emphasized in Professor Ghilarov's work on soil animal adaptations. Biology and Fertility of Soils, 3, 39-44.

Wigglesworth, V.B. (1965) The principles of insect physiology. Methuen, London.

Witteveen, J., Verhoef, H.A. \& Letschert, J.P.W. (1987) Osmotic and ionic regulation in marine littoral Collembola. Journal of Insect Physiology, 33, 59-66. 
Appendix S2e: Identification and interpretation of biogeographic provinces. except South-East Asia) origin of each biogeographic province was estimated from maps by McLoughlin (2001), except for Macaronesia (volcanic islands of North Atlantic) and Central America which did not exist at the time of Pangea disruption and the spread of present-day continents. Obviously, these two biogeographic distributions are strongly linked but they are not identical. While all 20 species from the former Laurasia domain are extra-tropical, only 8 of the 12 species from former Gondwana domain are tropical. In the latter analyses we only accounted for the 32 species which could be classified for both tropical/non-tropical and

Gondwana/Laurasia distribution, permitting better comparability. Accounting for all species, however, lead to the same qualitative conclusions. We are aware of the fact that strong geographic discrepancies exist in the sampling effort devoted to Collembola (Deharveng, 2004). This is why we used the number of records per species (used as a proxy for sampling effort) to check for the absence of biases due to sampling imbalances (see Appendix S2c). environmental harshness. For species that are particularly sensitive to moisture deficits, such as the majority of Collembola, regions receiving a high amount of rainfall will on average be less harsh. For species that are not able to increase their body temperature above that of the immediate environment, such as again Collembola, regions of high temperatures will on average be less harsh. In that sense, the Inter-Tropical Convergence Zone, with a reasonably warm (cloudy) and moist climate, will be favorable to most sensitive species. Besides

2684 coldness and aridity, acid and metal-contaminated soils were also considered as harsh 
2685

habitats. Indeed, most tropical soils are acid, at least they exhibit $\mathrm{pH}$ values less than 5.

2686

However, if we except areas degraded by human activities in the tropics (pasture, mining,...),

2687 tropical rain forests are not characterized by nutrient shortage, due to (i) high organic inputs

2688 from the overstory, (ii) a high rate of mineral weathering in the soil. Tropical soils are fragile but not poor in nutrients, at least in the top few centimeters where most soil animals (Willemia included) are living (see Dos Santos Neves et al., 2010; Brookshire et al., 2012). Obviously, tropical areas also include harsher environments (which have been coded as such in our database), more especially in mountains above $3000 \mathrm{~m}$ (the Andes), white sands and seashores. As explained in the Introduction, during much of the geological past, environments might have been on average harsher on Laurasia rather than on Gondwana paleocontinents (Vršanský, 2005; Crisp et al., 2010), among others reflecting the larger surface of landmasses of northern than of southern temperate regions which may lead to more climatic and thereby edaphic extremes in Laurasia and descendant land masses (except for Antarctica) (Chown et al., 2004).

\section{REFERENCES}

Brookshire E.N.J., Gerber, S., Menge, D.N.L. \& Hedin, L.O. (2012) Large losses of inorganic nitrogen from tropical rainforests suggest a lack of nitrogen limitation. Ecology Letters, 15, 9-16.

Chown, S.L., Sinclair, B.J., Leinaas, H.P. \& Gaston, K.J. (2004) Hemispheric asymmetries in biodiversity: a serious matter for ecology. PLoS Biology, 2, e406.

Crisp, M.D., Isagi, Y., Kato, Y., Cook, L.G. \& Bowman, D.M.J.S. (2010) Livistona palms in Australia: ancient relics or opportunistic immigrants? Molecular Phylogenetics and Evolution, 54, 512-523. 
Deharveng, L. (2004) Recent advances in Collembola systematics. Pedobiologia, 48, 415433.

Dos Santos Neves, N., Feer, F., Salmon, S., Chateil, C. \& Ponge, J.F. (2010) The impact of red howler monkey latrines on the distribution of main nutrients and on topsoil profiles in a tropical rain forest. Austral Ecology, 35, 549-559.

McLoughlin, S. (2001) The breakup history of Gondwana and its impact on pre-Cenozoic floristic provincialism. Australian Journal of Botany, 49, 271-300.

Vršanský, P. (2005) Mass mutations of insects at the Jurassic/Cretaceous boundary? Geologica Carpathica, 56, 473-481.

Appendix 3 - Table. Biogeographic provenance of Willemia species. Biogeographic provinces according to Christiansen \& Bellinger (1995). Gondwana-inherited provin type, Eurasia-inherited provinces in italic type, non-defined (Macaronesia and Central America) in normal type. Species belonging to both old continents were classified a Columns corresponding to tropical provinces are shaded

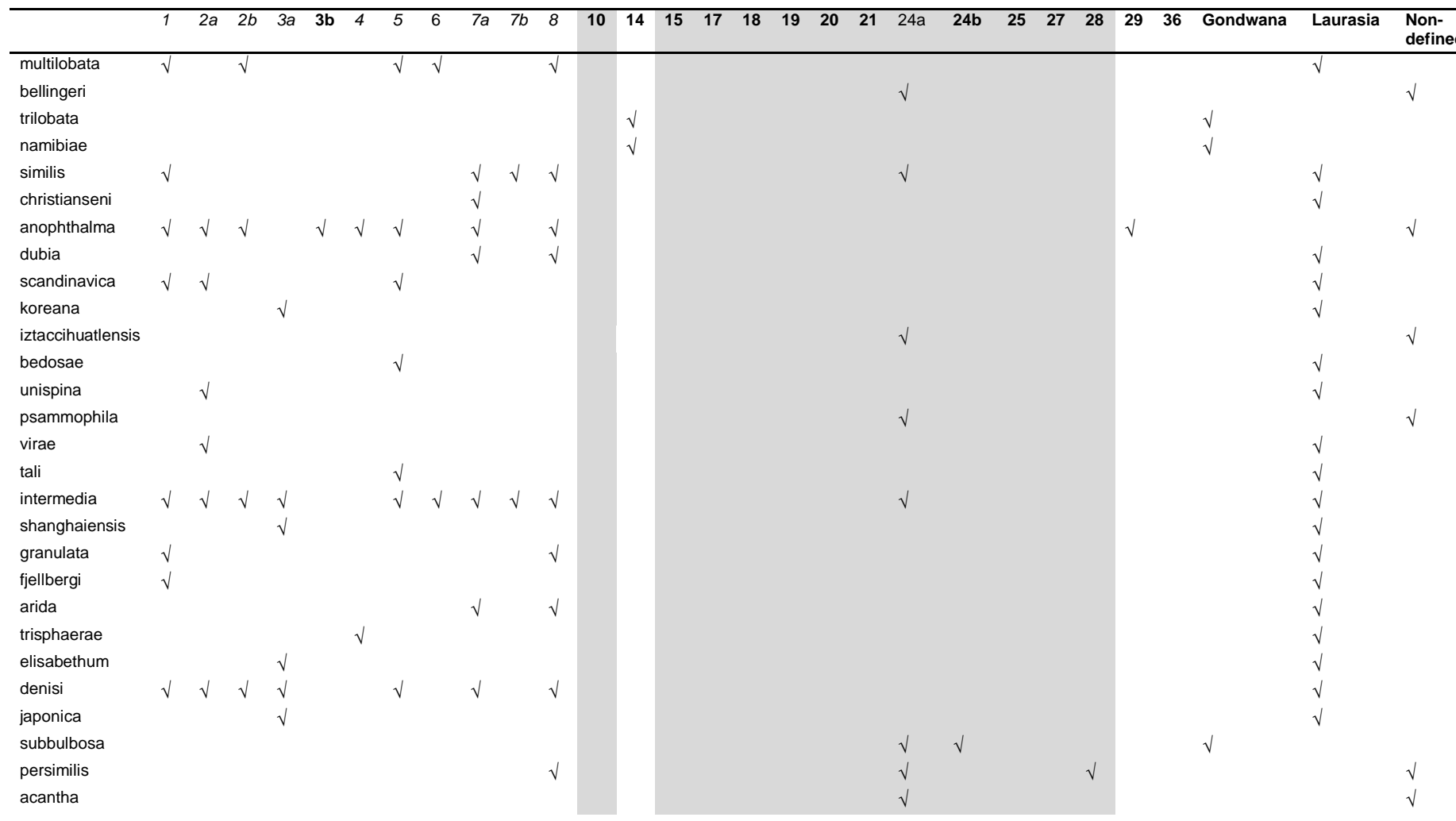


bulbosa

meybholae

arenicola

nepalensis

neocaledonica

nadchatrami

brevispina

annapurna

buddenbrocki

wandae

nosyboraha

delamarei

setonychia

deharvengi $\sqrt{ }$

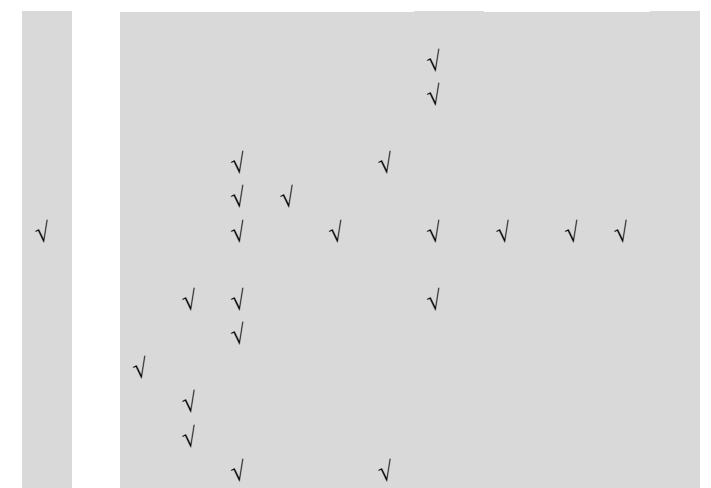

2720

2721 
2722 Appendix S3. Robustness of the analysis to variation in underlying phylogenetic trees

2723 We have performed again all analyses with the 6 most parsimonious trees. The 6 trees are

2724 given below.

2725 According to all these analyses, the results obtained with the 6 most parsimonious trees are

2726 equivalent to those obtained with the resulting tree used in the main text.
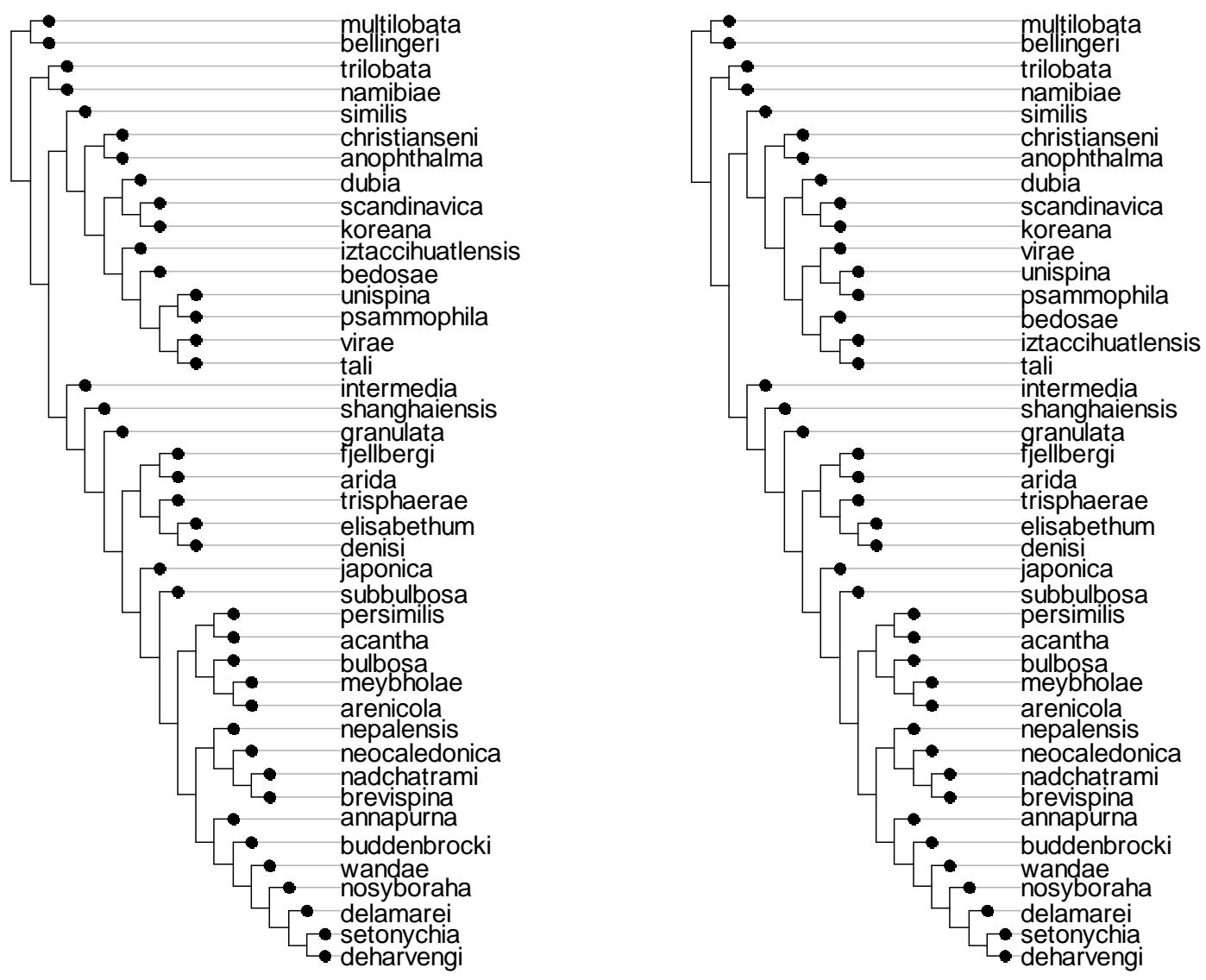

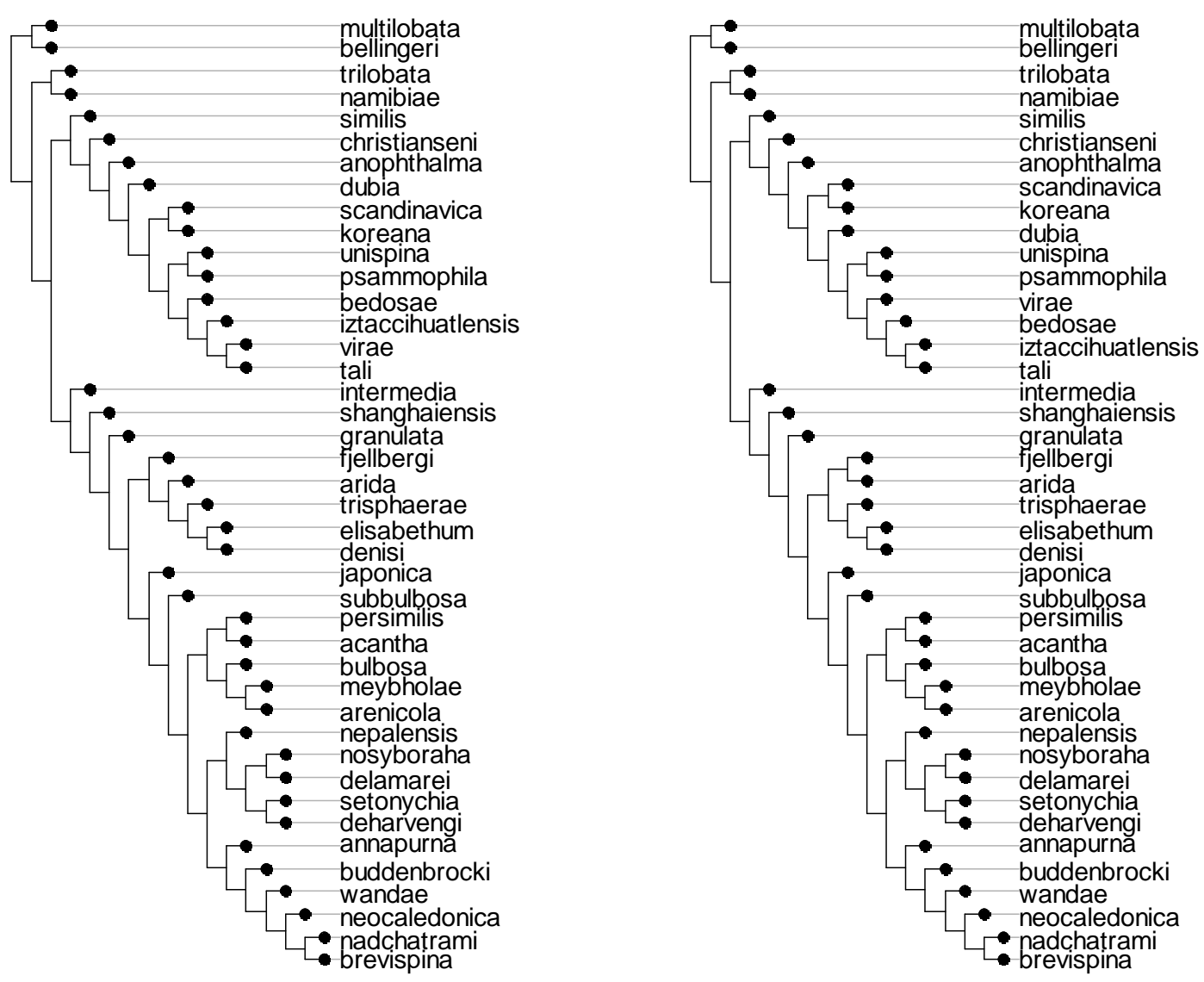

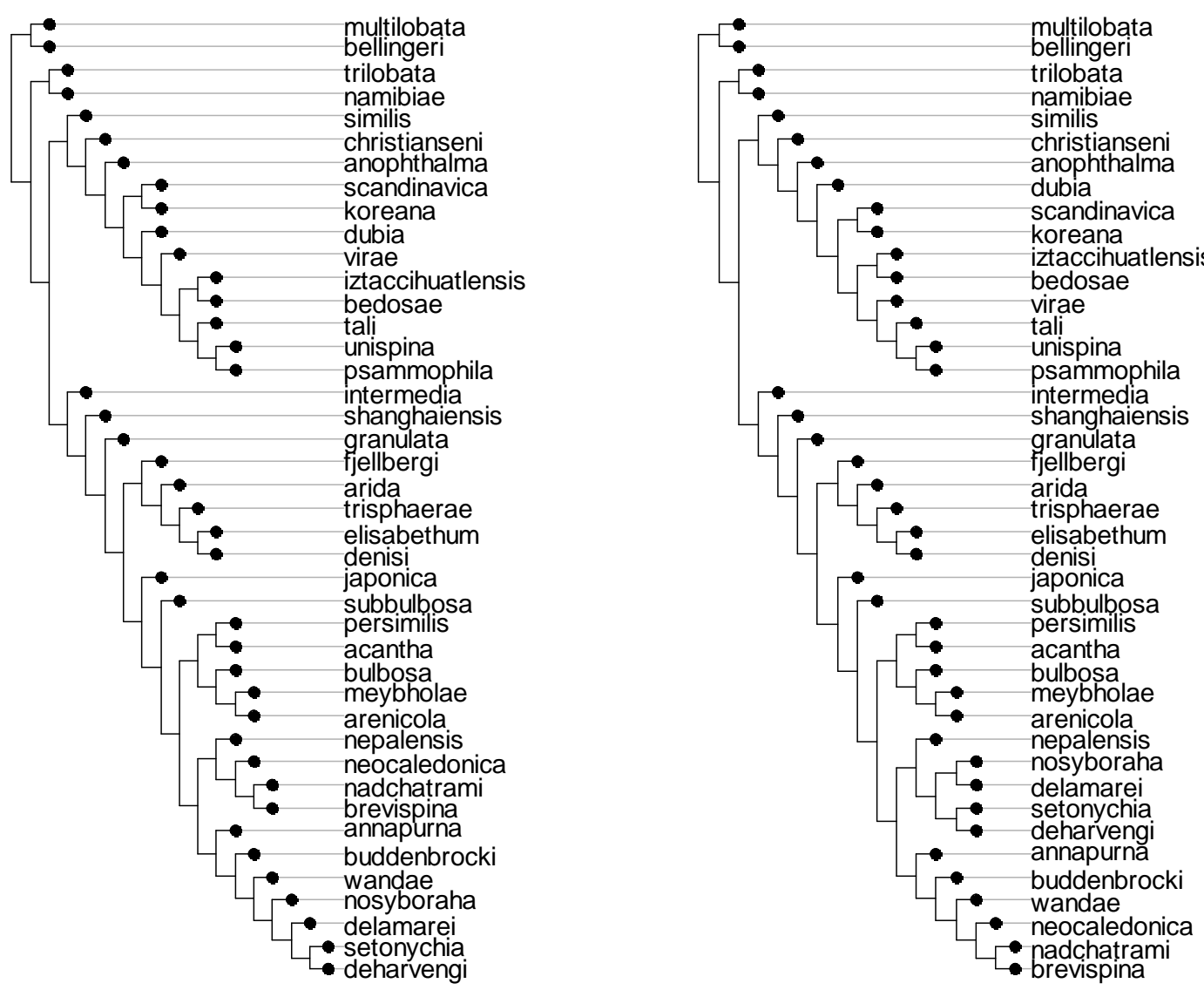

2733 With all phylogenetic trees, the types of harshness under which species were found exhibited

2734 clear phylogenetic conservatism (root-skewness test $\mathrm{P}$ values varied from 0.001 to 0.003 for a 2735 statistic varying from 0.616 to $0.647,1$ meaning that the whole trait variation is at the root node). Also the number of types of harsh habitats used by a species was phylogenetically conserved (root-skewness test $\mathrm{P}$ values varied from 0.013 to 0.043 , for a statistic varying from 0.623 to 0.660$)$. When salinity was excluded from the array of harsh habitats a stronger conservatism was registered (root-skewness test $\mathrm{P}$ values varied from 0.001 to 0.019 , for a

2740 statistic varying from 0.659 to 0.699$)$. The presence/absence of Willemia species in harsh

2741 habitats (instead of their number used) exhibited an even clearer phylogenetic conservatism 
2742 when salinity was excluded from the array of harsh habitat (root-skewness test with all P

2743 values equal to 0.001 , for a statistic varying from 0.754 to 0.786 ).

\section{Uses of most types of harsh habitats are positively correlated}

2745 Phylogenetic principal components analysis (pPCA) showed strong positive correlations

2746 between all types of harsh habitats, with the exception of salinity. Use of all other types of

2747 harsh habitats scored distinctly positively on the same Principal Component (Fig. 1). 
2749 Appendix S3 Table. Ordination of correlations between uses of different types of harsh

2750 habitats, analysed by pPCA analysis (multivariate analysis based on phylogenetic distances).

2751 The table gives coordinates of harsh habitat types along the first principal component for the 6

2752 dichotomous phylogenies provided above. Note that except for salinity, uses of habitats of all

2753 types of harshness are positively correlated.

\begin{tabular}{|l|c|c|c|c|c|c|}
\hline & Phy1 & Phy2 & Phy3 & Phy4 & Phy5 & Phy6 \\
\hline Xeric & -.343 & -.398 & -.396 & -.414 & -.426 & -.395 \\
\hline Hydric & -.183 & -.177 & -.190 & -.176 & -.181 & -.188 \\
\hline Arctic & -.389 & -.395 & -.380 & -.420 & -.398 & -.373 \\
\hline Alpine & -.482 & -.453 & -.461 & -.432 & -.450 & -.470 \\
\hline Acid & -.581 & -.559 & -.566 & -.548 & -.552 & -.567 \\
\hline Metallic & -.201 & -.198 & -.197 & -.202 & -.190 & -.195 \\
\hline Saline & .296 & .312 & .303 & .305 & .291 & .299 \\
\hline
\end{tabular}

Species using harsh habitats have lower clade ranks but are as numerous as species using mesic habitats

We found that the clade rank of species decreased with species' harshness breadth (PGLS; $\mathrm{df}=40, \mathrm{P}$ values varied from 0.002 to 0.003 depending on the dichotomous phylogeny used). When salinity was excluded it appeared that the distance to the root of the phylogenetic tree was quite similar for all species using harsh habitats, independent of the number of harsh 
2762 habitat types they were using, all of the harshness-tolerant species being placed in a basal position (Appendix S4 Figure).

Phy1

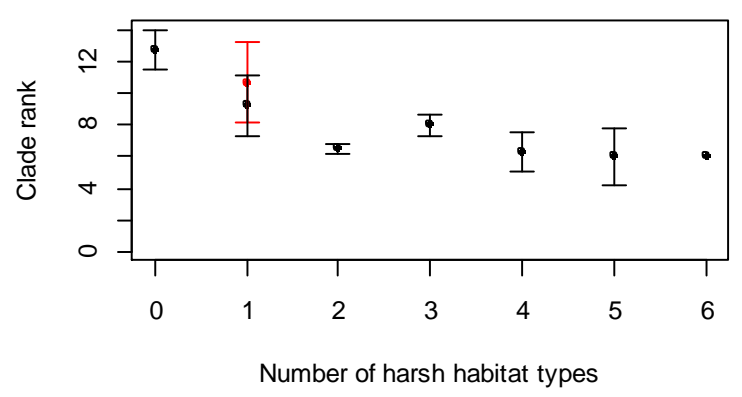

Phy3

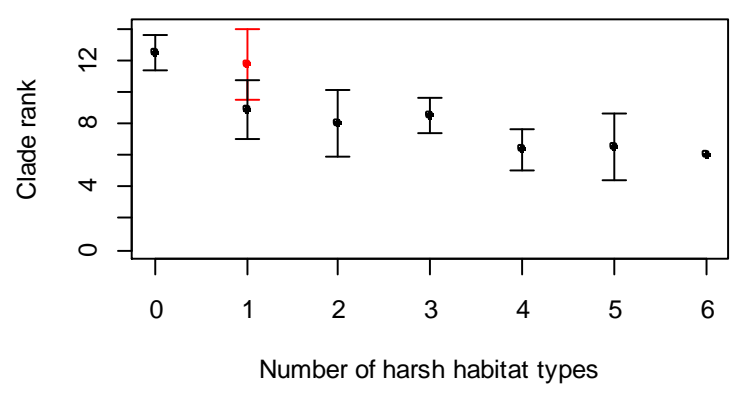

Phy5

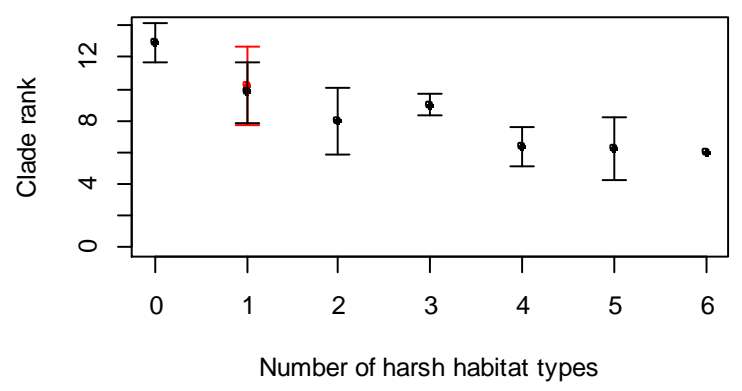

Phy2

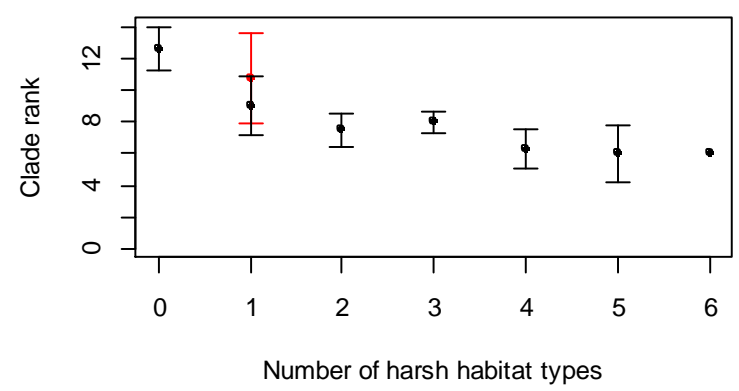

Phy4

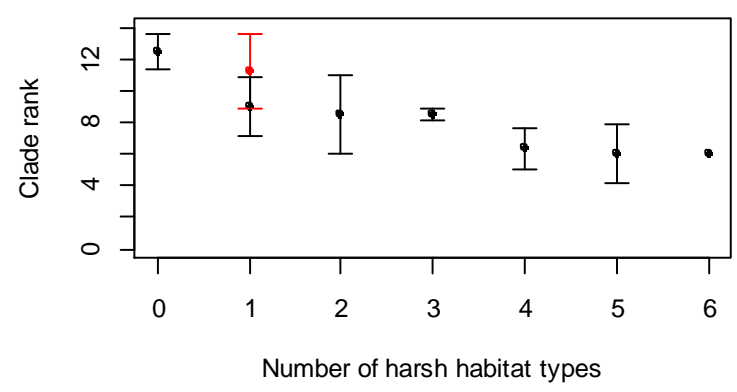

Phy6

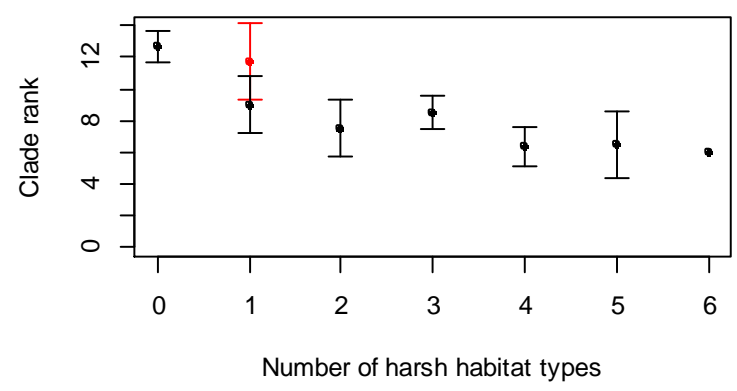

Appendix S3 Figure. Clade ranks, i.e. nodal distances to the root, of species using different numbers of harsh habitat types. Error bar $=$ S.E. Note that species that do not use any harsh habitat are at a higher distance from the root (see text for analyses). This analysis has been done for each dichotomous phylogenetic tree given above. Species having a single harsh habitat type have been separated into those affected by salinity (red) and those affected by another harsh habitat type (black). 
2772 Geographical distributions: Species using harsh habitats tend to be Laurasian, and as a

\section{3 statistical consequence Laurasians tend to have low clade ranks}

2774 We found that species using harsh and mesic habitats were distributed differently across the 2775 globe. Species using harsh habitats tended to occur in present non-tropical regions, albeit the 2776 relationship was relatively weak (PGLS; $\mathrm{df}=30$; $\mathrm{P}$ values varying from 0.0004 to 0.0553 ). At 2777 the same time, species using harsh habitats were strongly restricted to former Laurasia regions 2778 (PGLS; $\mathrm{df}=30 ; \mathrm{P}$ values varying from 0.0002 to 0.0103 ).

Low clade-rank species were strongly restricted to present non-tropical regions $(n=31$

2780 in all tests of this paragraph, tests based on phylogenetic permutations, all $\mathrm{P}$ values equal

27810.001 whatever the dichotomous phylogenetic tree used). This relationship was maintained

2782 when including harshness breadth as a co-variable: harshness breadth and presence in present2783 day tropical regions were both related to low clade rank ( $\mathrm{P}$ values were equal to 0.001 for 2784 harshness breadth, and they varied from 0.001 to 0.009 for presence in present-day tropical 2785 regions depending on the phylogenetic tree used; conclusions were not impacted by the order 2786 in which the two explanatory variables were entered in the model: changing the order gave $\mathrm{P}$ 2787 varying from 0.034 to 0.051 for harshness breadth, and equal 0.001 for presence in present2788 day tropical regions). Therefore the high harshness-tolerance of non-tropical species did not 2789 explain their low clade rank. Species of low clade rank also tended to be restricted to former 2790 Laurasia regions (P varied from 0.005 to 0.013 depending on the phylogenetic tree used).

2791 When including first occurrence in former Laurasia and second harshness breadth, both 2792 variables were significant ( $\mathrm{P}$ varied from 0.002 to 0.004 for occurrence in former Laurasia, 2793 and from 0.007 to 0.017 for harshness breadth). But this relationship disappeared when 2794 including first harshness breadth in the model: occurrence in former Laurasia was not 2795 significant (P varying 0.239 from to 0.294 ) while harshness breadth was significantly related 
2796 to low clade rank (P varying from 0.001 to 0.002). Overall, this indicated that species using

2797 harsh environments are particularly bound to former Laurasia continents (above paragraph)

2798 and that - as a statistical consequence - we find many species of low clade rank on former

2799 Laurasia continents. 


\section{Reconstructions of ancestral states}

2801 The below graphs show the reconstructions of the three traits analysed for each of the six 2802 trees. Visiul inspection shows that the different trees lead to the same conclusions on which 2803 trait states are ancestral and when they have changed throughout evolution.

A - use of harsh habitats Tree 1

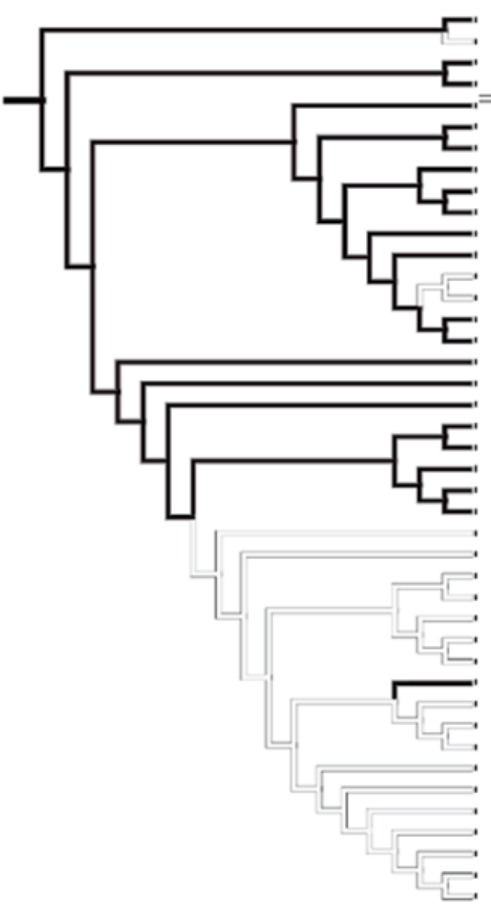

A - use of harsh habitats Tree 2

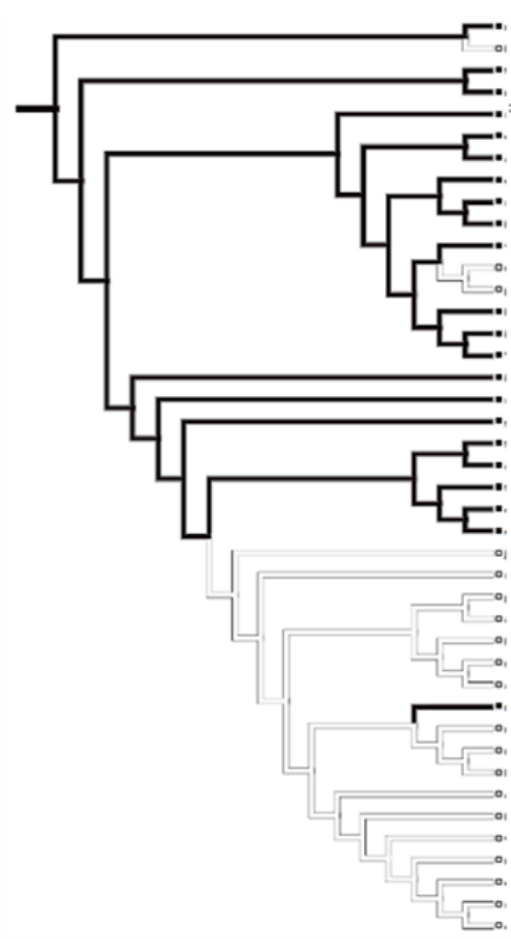

B - tropical distribution

C-former-Gondwana distribution

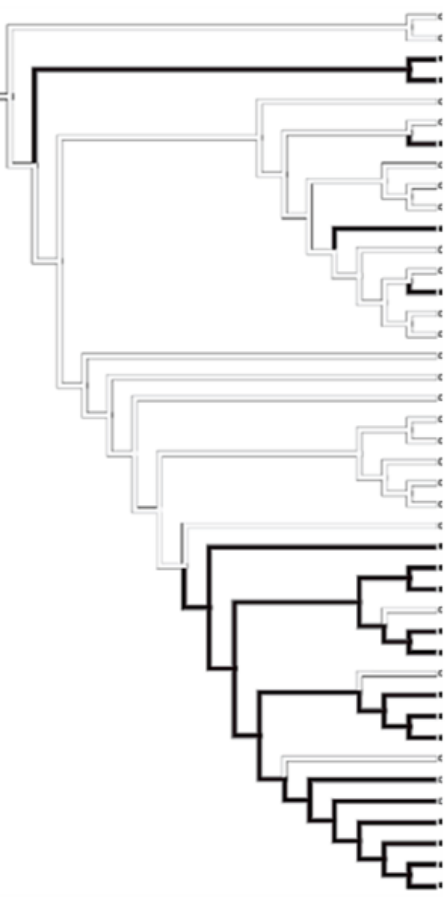

B - tropical distribution

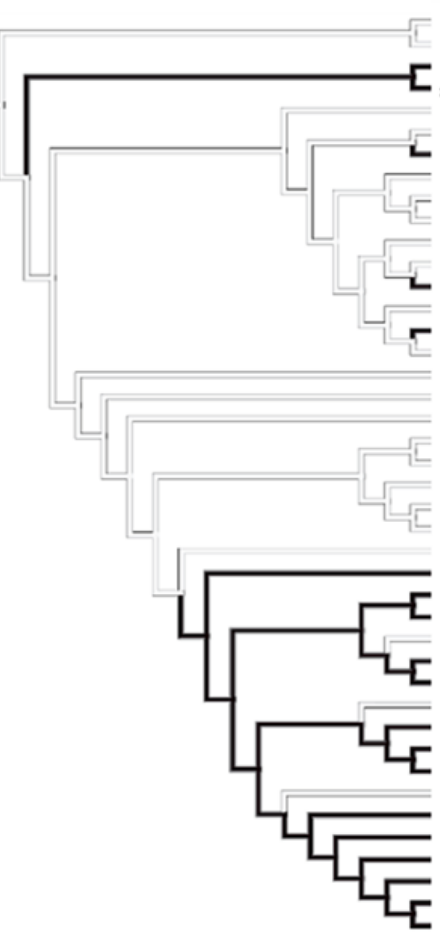

$\mathrm{C}$ - former-Gondwana distribution
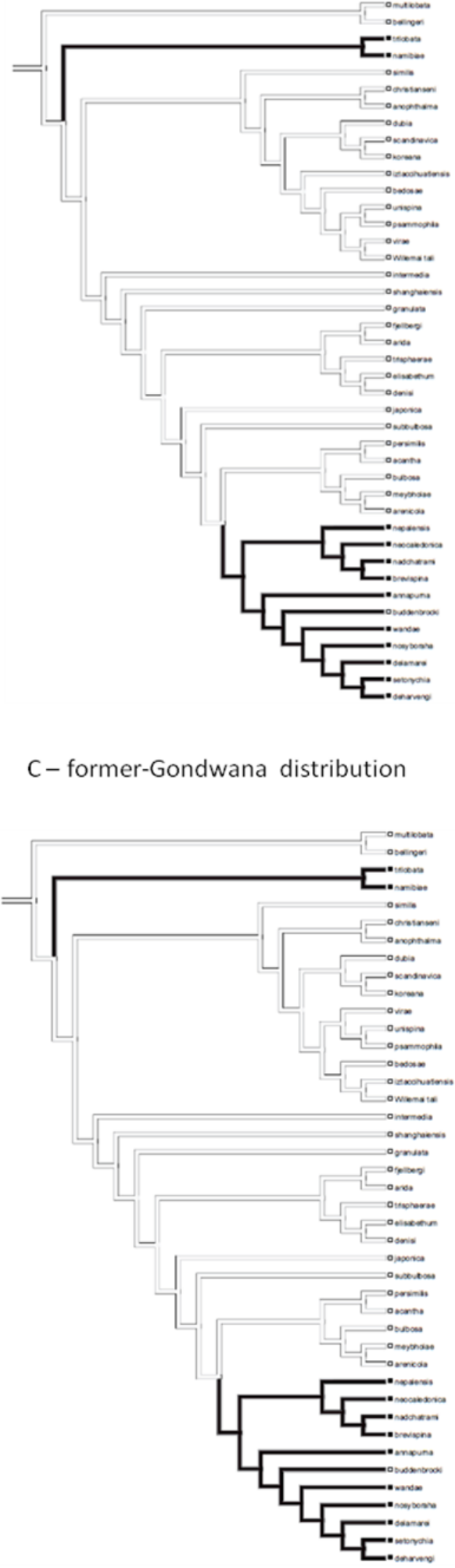


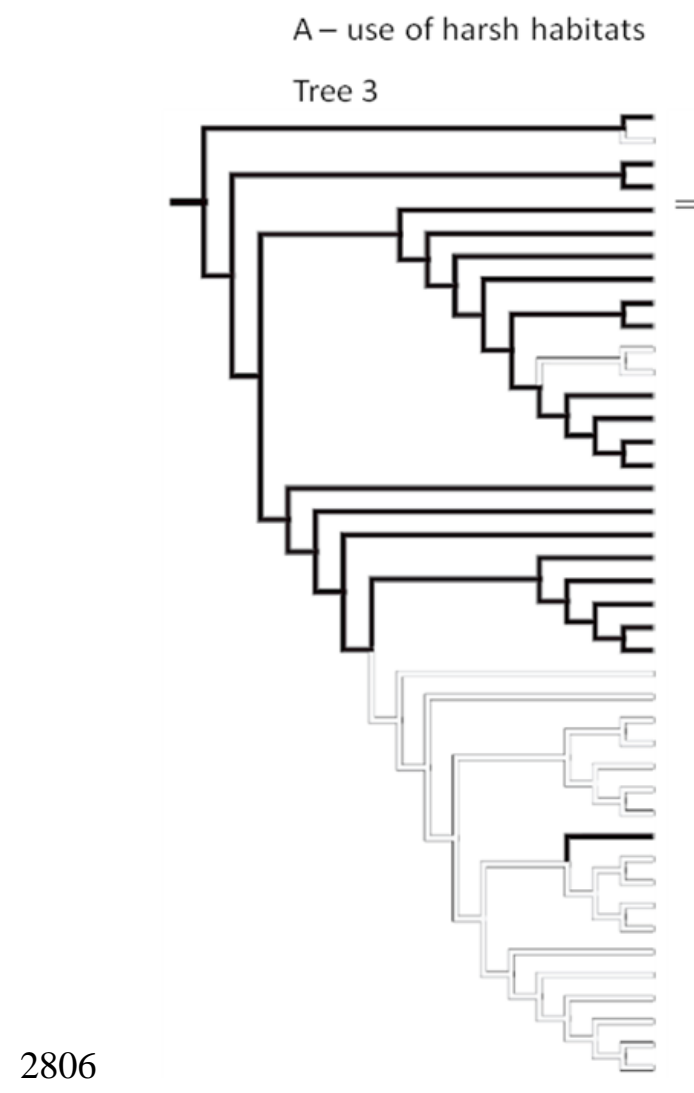

B - tropical distribution

C- former-Gondwana distribution Tree 3
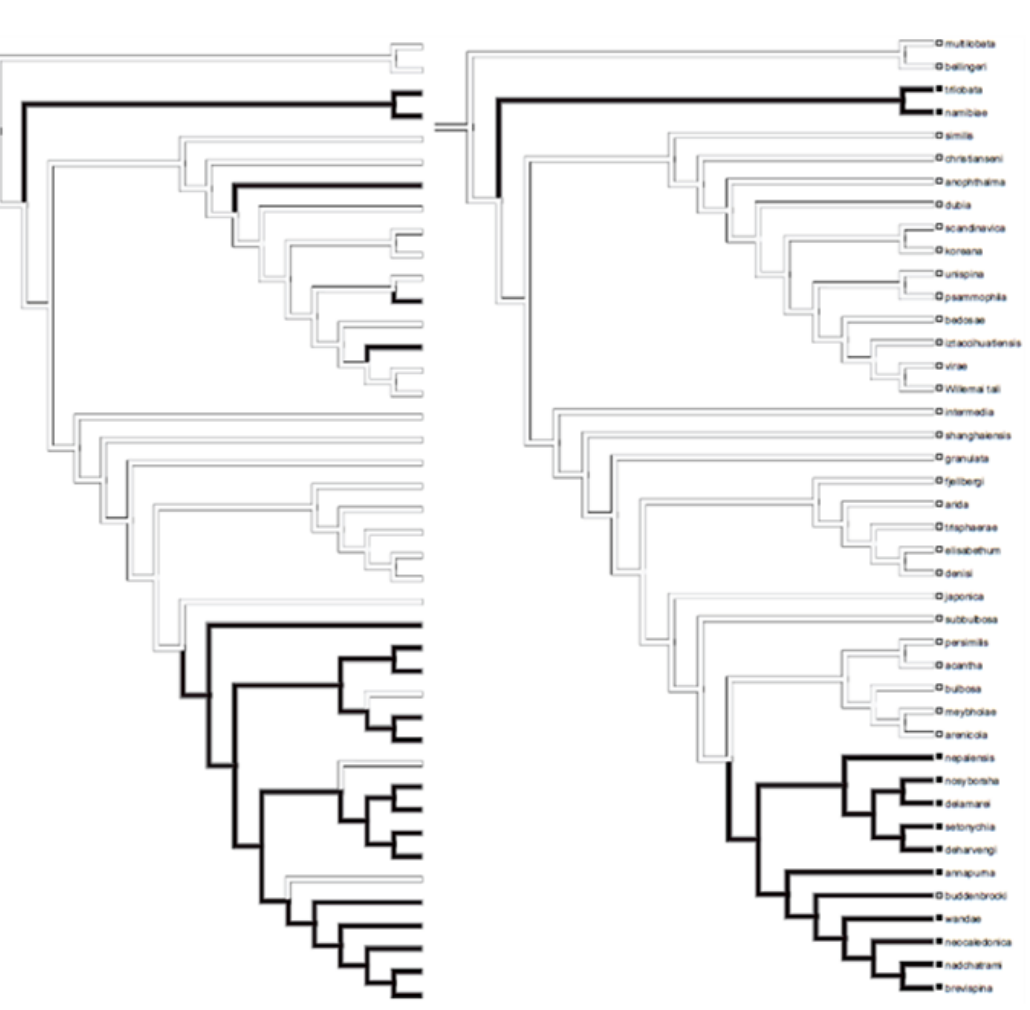

A - use of harsh habitats B - tropical distribution

C- former-Gondwana distribution Tree 4
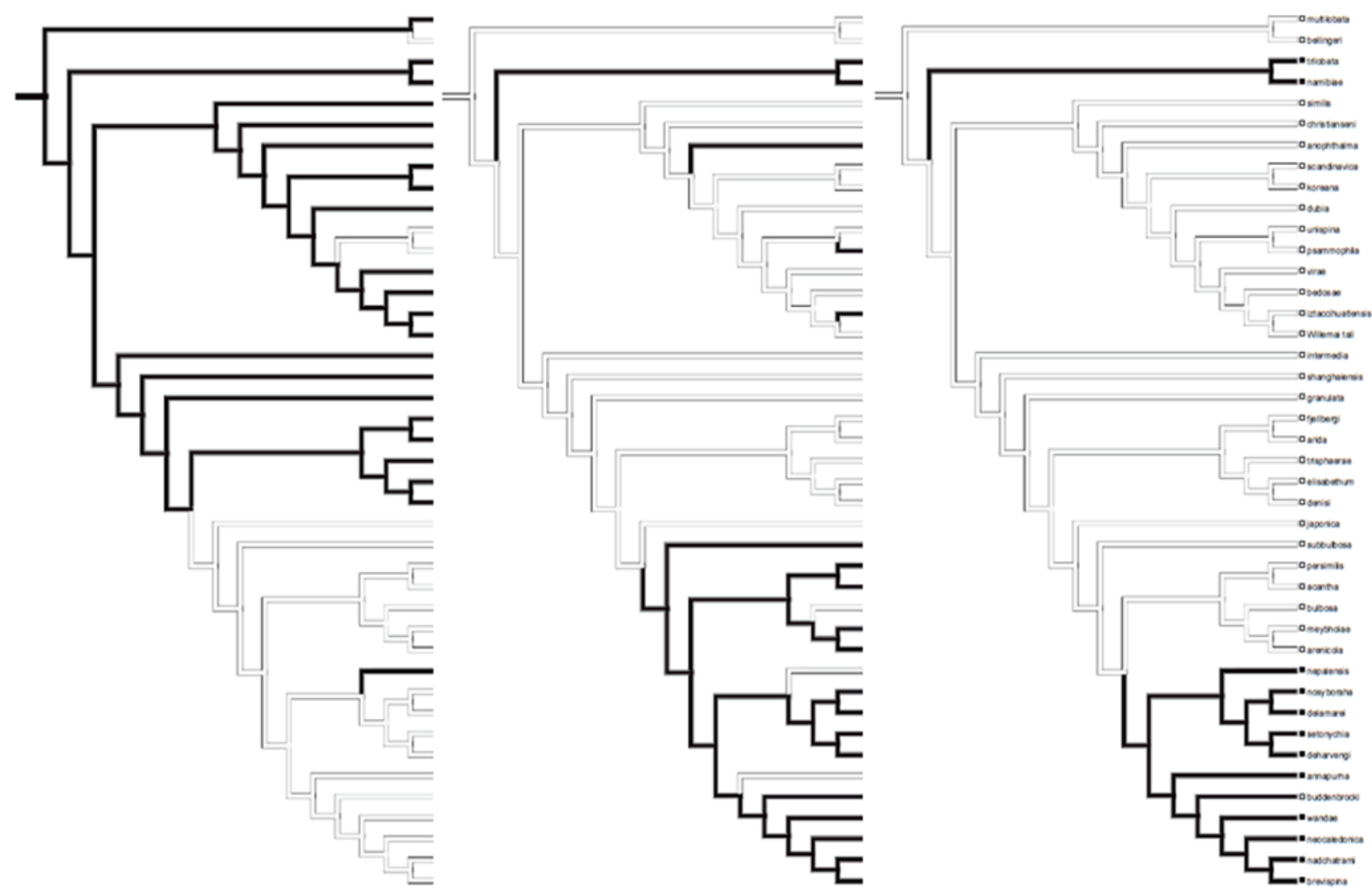
A- use of harsh habitats

B - tropical distribution

$\mathrm{C}$ - former-Gondwana distribution

Tree 5

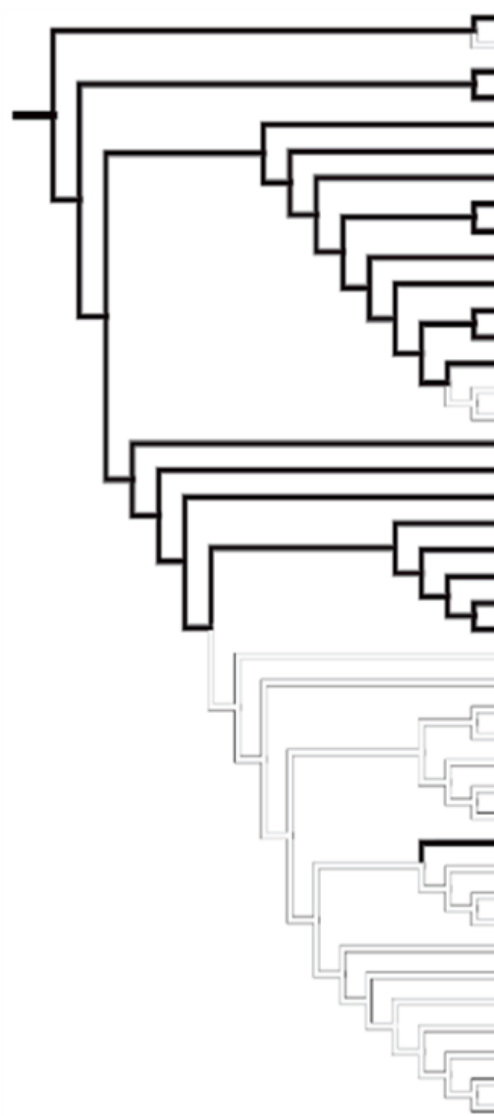

A - use of harsh habitats Tree 6
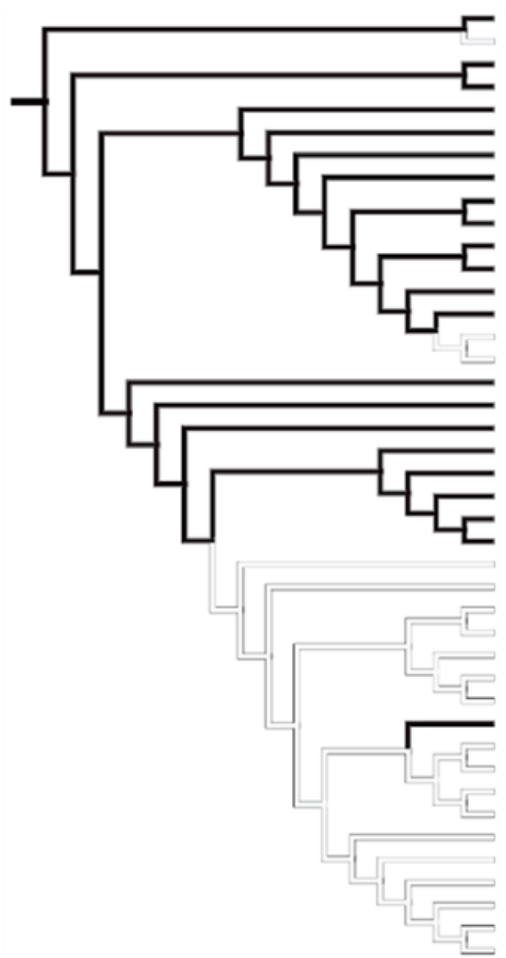
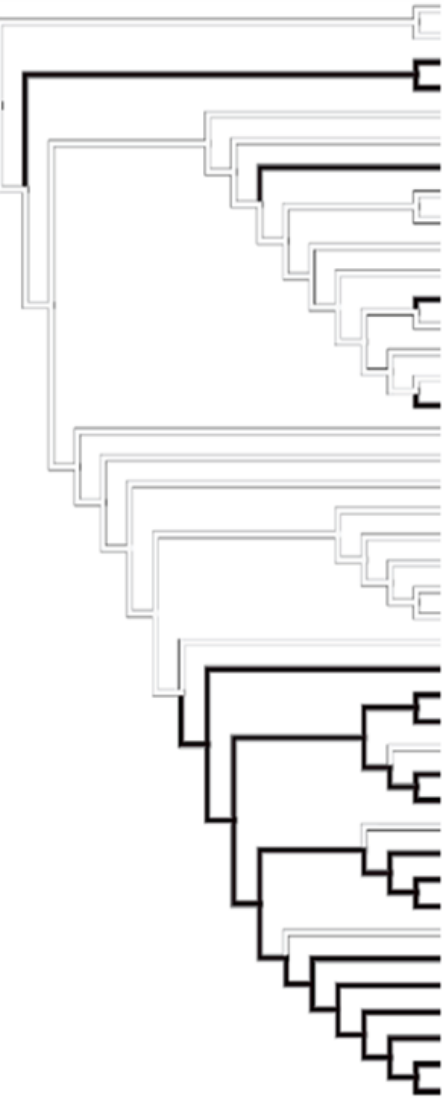

B - tropical distribution

C- former-Gondwana distribution

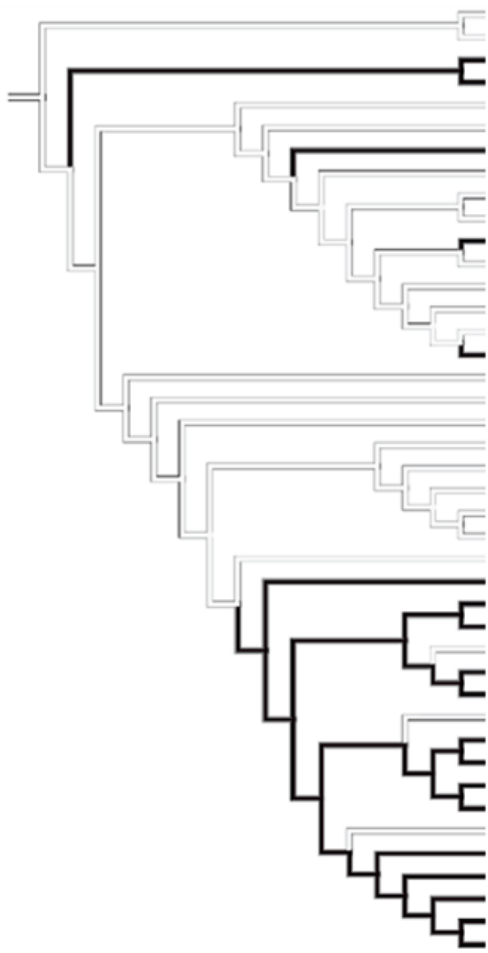

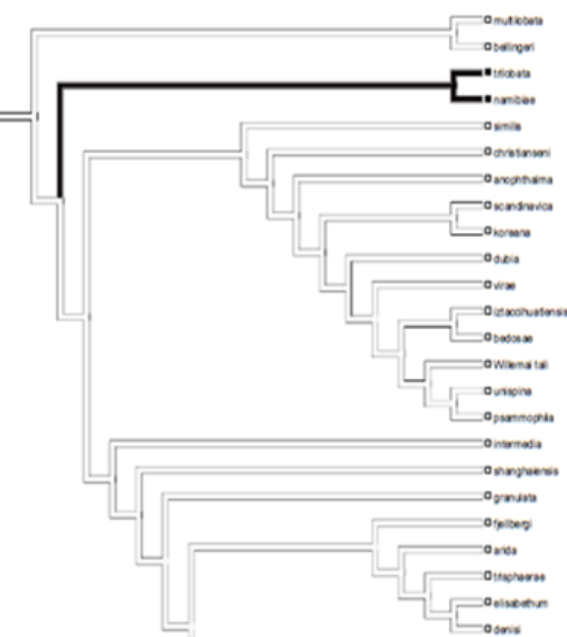

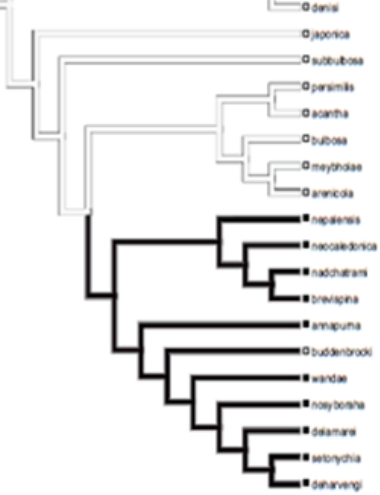

